\title{
ESTIMATING DESIGN-FLOOD DISCHARGES FOR STREAMS IN IOWA USING DRAINAGE-BASIN AND CHANNEL-GEOMETRY \\ CHARACTERISTICS
}

By David A. Eash

U.S. GEOLOGICAL SURVEY

Water-Resources Investigations Report 93-4062

Prepared in cooperation with the IOWA HIGHWAY RESEARCH BOARD and the HIGHWAY DIVISION of the IOWA DEPARTMENT OF TRANSPORTATION (Iowa DOT Research Project HR-322)

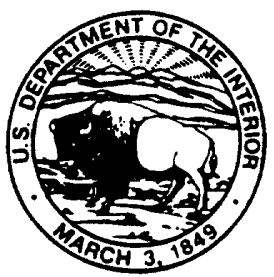

Iowa City, Iowa 1993 


\title{
U.S. DEPARTMENT OF THE INTERIOR
}

\author{
BRUCE BABBITT, Secretary
}

\author{
U.S. GEOLOGICAL SURVEY
}

Robert M. Hirsch, Acting Director

For additional information write to:

District Chief

U.S. Geological Survey

Rm. 269, Federal Building

400 South Clinton Street

Iowa City, Iowa 52244
Copies of this report can be purchased from:

U.S. Geological Survey

Books and Open-File Reports

Federal Center, Bldg. 810

Box 25425

Denver, Colorado 80225 


\section{CONTENTS}

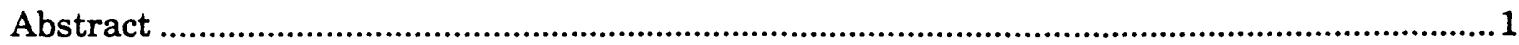

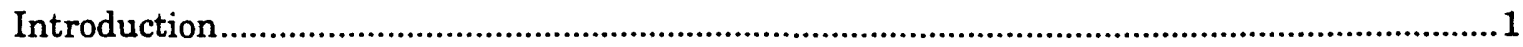

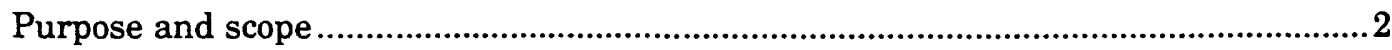

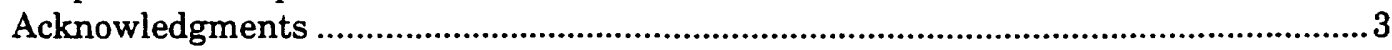

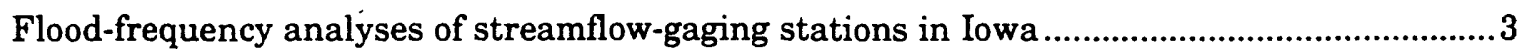

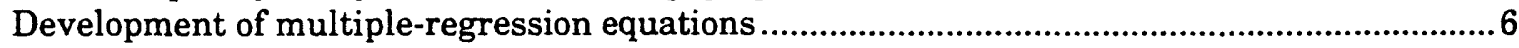

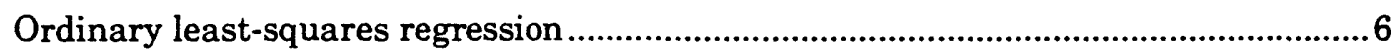

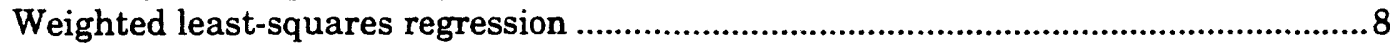

Estimating design-flood discharges using drainage-basin characteristics ..............................9

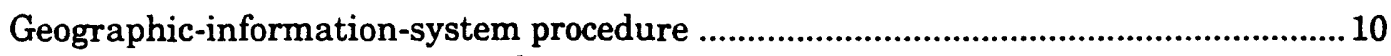

Verification of drainage-basin characteristics ..................................................... 13

Drainage-basin characteristic equations ............................................................... 16

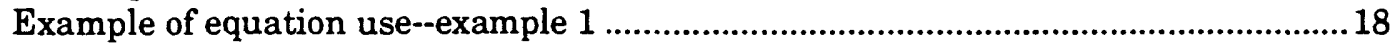

Estimating design-flood discharges using channel-geometry characteristics ........................ 19

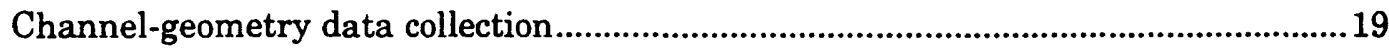

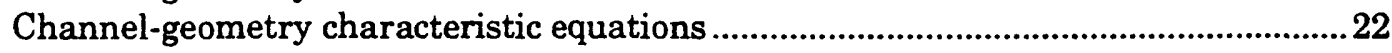

Analysis of channel-geometry data on a statewide basis..............................22

Analysis of channel-geometry data by selected regions...................................22

Comparison of regional and statewide channel-geometry equations..............24

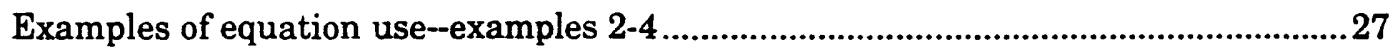

Application and reliability of flood-estimation methods.....................................................32

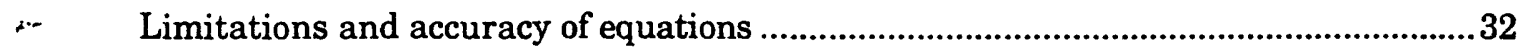

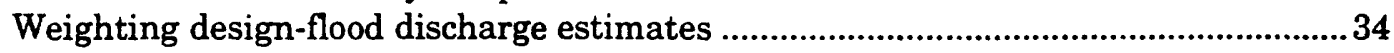

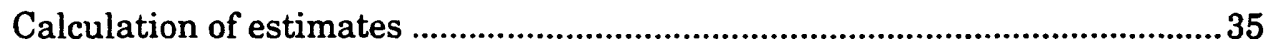

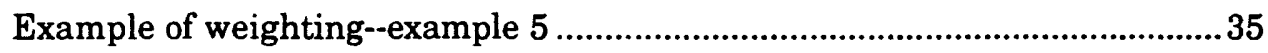

Weighting design-flood discharge estimates for gaged sites .................................... 35

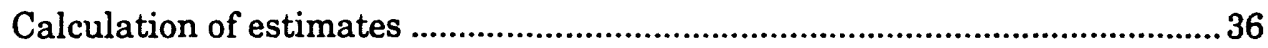

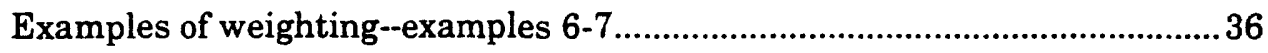

Estimating design-flood discharges for an ungaged site on a gaged stream ................37

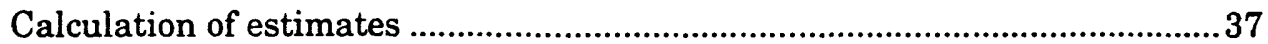

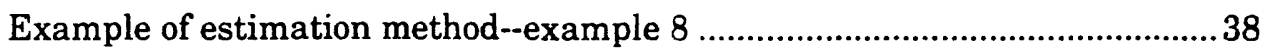

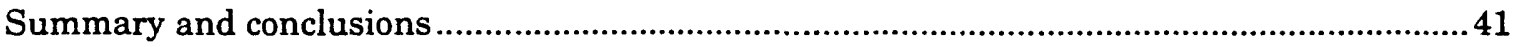

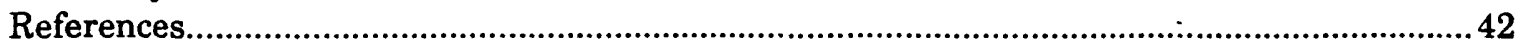




\section{CONTENTS--Continued}

Appendix A. Selected drainage-basin characteristics quantified using a geographicinformation-system procedure

Appendix B. Techniques for manual, topographic-map measurements of primary drainage-basin characteristics used in the regression equations

Appendix C. Procedure for conducting channel-geometry measurements .53

\section{ILLUSTRATIONS}

Figure 1. Map showing location of streamflow-gaging stations used to collect drainage-basin data

2. Map showing location of streamflow-gaging stations used to collect channel-geometry data and regional transition zone...........................................5

3. Graph showing example of a flood-frequency curve.........................................

4. Map showing four geographic-information-system maps that constitute a digital representation of selected aspects of a drainage basin .........................11

5. Map showing distribution of 2-year, 24-hour precipitation intensity for Iowa and southern Minnesota ..................................................................... 13

6. Block diagram of a typical stream channel ..................................................20

7. Photographs showing active-channel and bankfull reference levels at six streamflow-gaging stations in Iowa

8. Graphs showing relation between 2-year recurrence-interval discharge and channel width for bankfull and active-channel width regression equations

9. Graphs showing relation between 100-year recurrence-interval discharge and channel width for bankfull and active-channel width regression equations

10. Graph showing bankfull cross section for Black Hawk Creek at Grundy Center 


\section{TABLES}

Table 1. Comparisons of manual measurements and geographic-informationsystem-procedure measurements of selected drainage-basin characteristics at selected streamflow-gaging stations ................................. 14

2. Statewide drainage-basin characteristic equations for estimating designflood discharges in Iowa

3. Statewide channel-geometry characteristic equations for estimating design-flood discharges in Iowa.

4. Region I channel-geometry characteristic equations for estimating designflood discharges in Iowa outside of the Des Moines Lobe landform region

5. Region II channel-geometry characteristic equations for estimating designflood discharges in Iowa within the Des Moines Lobe landform region

6. Statistical summary for selected statewide drainage-basin and channelgeometry characteristics, and for selected regional channel-geometry characteristics at streamflow-gaging stations in Iowa

7. Comparisons of manual measurements made from different scales of topographic maps of primary drainage-basin characteristics used in the regression equations

8. Flood-frequency data for streamflow-gaging stations in Iowa

9. Selected drainage-basin and channel-geometry characteristics for streamflow-gaging stations in Iowa 


$\begin{array}{lll}\text { Multiply } & \text { By } & \text { To obtain } \\ \text { inch (in.) } & 25.4 & \text { millimeter } \\ \text { foot (ft) } & 0.3048 & \text { meter } \\ \text { mile (mi) } & 1.609 & \text { kilometer } \\ \text { square mile }\left(\mathrm{mi}^{2}\right) & 2.590 & \text { square } \mathrm{kilometer} \\ \text { foot per mile }(\mathrm{ft} / \mathrm{mi}) & 0.1894 & \text { meter per kilometer } \\ \text { mile per square } \mathrm{mile}\left(\mathrm{mi} / \mathrm{mi}^{2}\right) & 0.621 & \text { kilometer per square } \\ & & \text { kilometer } \\ \text { cubic foot per second }\left(\mathrm{ft}^{3} / \mathrm{s}\right) & 0.02832 & \text { cubic meter per second }\end{array}$

Sea level: In this report, "sea level" refers to the National Geodetic Vertical Datum of 1929-a geodetic datum derived from a general adjustment of the first-order level nets of the United States and Canada, formerly called Sea Level Datum of 1929. 


\title{
ESTIMATING DESIGN-FLOOD DISCHARGES FOR STREAMS IN IOWA USING DRAINAGE-BASIN AND CHANNEL-GEOMETRY CHARACTERISTICS
}

\author{
By David A. Eash
}

\section{ABSTRACT}

\begin{abstract}
Drainage-basin and channel-geometry multiple-regression equations are presented for estimating design-flood discharges having recurrence intervals of $2,5,10,25,50$, and 100 years at stream sites on rural, unregulated streams in lowa. Design-flood discharge estimates determined by Pearson Type-III analyses using data collected through the 1990 water year are reported for the 188 streamflow-gaging stations used in either the drainage-basin or channel-geometry regression analyses. Ordinary least-squares multiple-regression techniques were used to identify selected drainage-basin and channel-geometry characteristics and to delineate two channel-geometry regions. Weighted leastsquares multiple-regression techniques, which account for differences in the variance of flows at different gaging stations and for variable lengths in station records, were used to estimate the regression parameters.
\end{abstract}

Statewide drainage-basin equations were developed from analyses of 164 streamflowgaging stations. Drainage-basin characteristics were quantified using a geographic-informationsystem procedure to process topographic maps and digital cartographic data. The significant characteristics identified for the drainage-basin equations included contributing drainage area, relative relief, drainage frequency, and 2-year, 24-hour precipitation intensity. The average standard errors of prediction for the drainagebasin equations ranged from 38.6 to 50.2 percent. The geographic-information-system procedure expanded the capability to quantitatively relate drainage-basin characteristics to the magnitude and frequency of floods for stream sites in lowa and provides a flood-estimation method that is independent of hydrologic regionalization.

Statewide and regional channel-geometry regression equations were developed from analyses of 157 streamflow-gaging stations. Channel-geometry characteristics were measured onsite and on topographic maps. Statewide and regional channel-geometry regression equations that are dependent on whether a stream has been channelized were developed on the basis of bankfull and active-channel characteristics. The significant channel-geometry characteristics identified for the statewide and regional regression equations included bankfull width and bankfull depth for natural channels unaffected by channelization, and active-channel width for stabilized channels affected by channelization. The average standard errors of prediction ranged from 41.0 to 68.4 percent for the statewide channel-geometry equations and from 30.3 to 70.0 percent for the regional channel-geometry equations.

Procedures provided for applying the drainage-basin and channel-geometry regression equations depend on whether the design-flood discharge estimate is for a site on an ungaged stream, an ungaged site on a gaged stream, or a gaged site. When both a drainage-basin and a channel-geometry regression-equation estimate are available for a stream site, a procedure is presented for determining a weighted average of the two flood estimates. The drainage-basin regression equations are applicable to unregulated rural drainage areas less than 1,060 square miles, and the channel-geometry regression equations are applicable to unregulated rural streams in lowa with stabilized channels.

\section{INTRODUCTION}

Knowledge of the magnitude and frequency of floods is essential for the effective management of flood plains and for the economical planning and safe design of bridges, culverts, levees, and other structures located along streams. Long-term flood data collected from a network of streamflow-gaging stations operated in Iowa are available for hydrologic analysis to compute design-flood discharge estimates for the gaged sites as well as for ungaged sites on the gaged streams. Techniques are needed to estimate design-flood discharges for sites on all 
ungaged streams in Iowa because most such stream sites in the State have no flood data available, particularly sites on smaller streams.

Flood runoff is a function of many interrelated factors that include, but are not limited to climate, soils, land use, and the physiography of drainage basins. Previous investigations for Iowa (Schwob, 1953, 1966; Lara, 1973, 1987) have been limited to the types of basin characteristics that can be investigated as potential explanatory variables for the development of multiple-regression floodestimation equations because many of the flood-runoff factors are difficult to measure. Previous investigations defined hydrologic regions to account for factors affecting flood runoff that were difficult to measure directly. The hydrologic regions were delineated on the basis of physiographic differences of broad geographic landform regions. However, two major limitations are encountered when using the hydrologic-region method to estimate flood discharges for ungaged sites. First, it is difficult to weight flood estimates for drainage basins located in more than one hydrologic region or located near the boundaries of hydrologic regions because the boundaries are not well defined. Regional boundaries are transitional zones where the physiographic characteristics of one hydrologic region gradually merge into another. Second, because large hydrologic regions may contain drainage basins with physiographies that are anomalous to the region in which they are located, it is difficult to correlate their physiographic differences to another hydrologic region, or to weight their flood estimates. Quantitative measurements of basin morphology to determine appropriate regional equations for drainage basins are not applicable for resolving these regional limitations. As a result, flood estimates for some ungaged sites become very subjective.

To address the need to minimize the subjectivity encountered in applying regional flood-estimation methods, a study using two different flood-estimation methods was made by the U.S. Geological Survey in cooperation with the Iowa Highway Research Board and the Highway Division of the Iowa Department of Transportation. Two new flood-estimation methods for Iowa, which are presumed to be independent from each other, were used in this study. An advantage in developing floodfrequency equations using two independent flood-estimation methods is that each method can be used to verify the results of the other, and the estimates obtained from each method can be used to calculate a weighted average.

Methods are now available to more easily quantify selected morphologic and climatic characteristics for a large number of drainage basins. A geographic-information-system (GIS) procedure developed by the U.S. Geological Survey uses topographic maps and digital cartographic data to quantify several basin characteristics that typically were not quantified previously. This GIS procedure expands the capability to relate drainage-basin characteristics to the magnitude and frequency of floods for stream sites in Iowa and provides a flood-estimation method that is independent of hydrologic regionalization.

Measurements of channel-geometry characteristics have been used to estimate the magnitude and frequency of floods in investigations conducted by Fields (1975), Webber and Roberts (1981), Parrett and others (1987), Hedman and Kastner (1977), and Osterkamp and Hedman (1982). These investigations have shown that measurements of specific channel-geometry characteristics provide a reliable method for estimating flood discharges because channel cross-sectional characteristics are assumed to be a function of flow volume and sediment-load transport (Pickup and Rieger, 1979, p. 41; Osterkamp, 1979, p. 2).

\section{Purpose and Scope}

The purpose of this report is to: (1) define equations for Iowa that relate measurable drainage-basin characteristics to design-flood discharges having recurrence intervals of 2,5 , $10,25,50$, and 100 years that are independent of hydrologic regionalization; (2) define corroborative equations for Iowa that relate channel-geometry characteristics to the same design-flood recurrence intervals; and (3) define application and reliability of drainage-basin and channel-geometry flood-estimation methods.

Both the drainage-basin and channelgeometry flood-estimation methods described in 
this report are applicable to unregulated rural streams located within the State. The drainage-basin flood-estimation method is limited to streams with drainage areas less than $1,060 \mathrm{mi}^{2}$. The channel-geometry floodestimation method is applicable to stabilized stream channels in Iowa.

\section{Acknowledgments}

The U.S. Army Corps of Engineers, Omaha and Rock Island Districts, contributed to the funding of the sediment-sample analyses. James J. Majure, formerly with the U.S. Geological Survey, Iowa City, Iowa, and now with the Iowa State University, GIS Support and Research Facility, Ames, Iowa, developed the computer software used to quantify the drainage-basin characteristics and the software used to integrate the overall GIS procedure.

\section{FLOOD-FREQUENCY ANALYSES OF STREAMFLOW-GAGING STATIONS IN IOWA}

Flood-frequency curves were developed for 188 streamflow-gaging stations operated in Iowa by the U.S. Geological Survey. They were developed according to procedures outlined in Bulletin 17B of the Interagency Advisory Committee on Water Data (IACWD, 1982, p. 1-28). These flood-frequency curves include data collected through the 1990 water year for both active and discontinued continuous-record and crest-stage gaging stations having at least 10 years of gaged annual-peak discharges. A water year is the 12-month period from October 1 through September 30 and is designated by the calendar year in which it ends. The locations of the 164 gaging stations studied using the drainage-basin flood-estimation method are shown in figure 1 , and the locations of the 157 gaging stations studied using the channelgeometry flood-estimation method are shown in figure 2. Map numbers for the gaging stations shown in figures 1 and 2 are referenced to gaging-station numbers and names in tables 8 and 9 (at end of this report). The observed annual-peak discharge record at each site includes water years during which the gaging station was operated, which is termed the systematic period of record. The observed annual-peak discharge record also may include historic-peak discharges that occurred during water years outside the systematic period of record.

A flood-frequency curve relates observed annual-peak discharges to annual exceedance probability or recurrence interval. Annual exceedance probability is expressed as the chance that a given flood magnitude will be exceeded in any 1 year. Recurrence interval, which is the reciprocal of the annual exceedance probability, is the average number of years between exceedances of a given flood magnitude. For example, a flood with a magnitude that is expected to be exceeded once on the average during any 100-year period (recurrence interval) has a 1-percent chance (annual exceedance probability $=0.01$ ) of being exceeded during any 1 year. This flood, commonly termed the 100-year flood, is generally used as a standard against which flood peaks are measured. Although the recurrence interval represents the long-term average period between floods of a specific magnitude, rare floods could occur at shorter intervals or even within the same year.

Flood-frequency curves were developed by fitting the logarithms (base 10) of the observed annual-peak discharges to a Pearson Type-III distribution using U.S. Geological Survey WATSTORE flood-frequency analysis programs (Kirby, 1981, p. C1-C57). Extremely small discharge. values (low outliers) were censored, adjustments were made for extremely large discharge values (high outliers), and the coefficient of skew was weighted for each gaging station with skew values obtained from a generalized skew-coefficient map (IACWD, 1982). Whenever possible, historically adjusted flood-frequency curves were developed to extend the flood record for gaging stations with historic peak-flood information.

The recommended equation (LACWD, 1982, p. 9) for fitting a Pearson Type-III distribution to the logarithms of observed annual-peak discharges of a gaging station is

$$
\log \left(Q_{\mathrm{T}(g)}\right)=\bar{x}+k s,
$$

where $Q_{\mathrm{T}(g)}$ is the design-flood discharge for a gage, in cubic feet per second, for a selected $\mathrm{T}$-year recurrence 


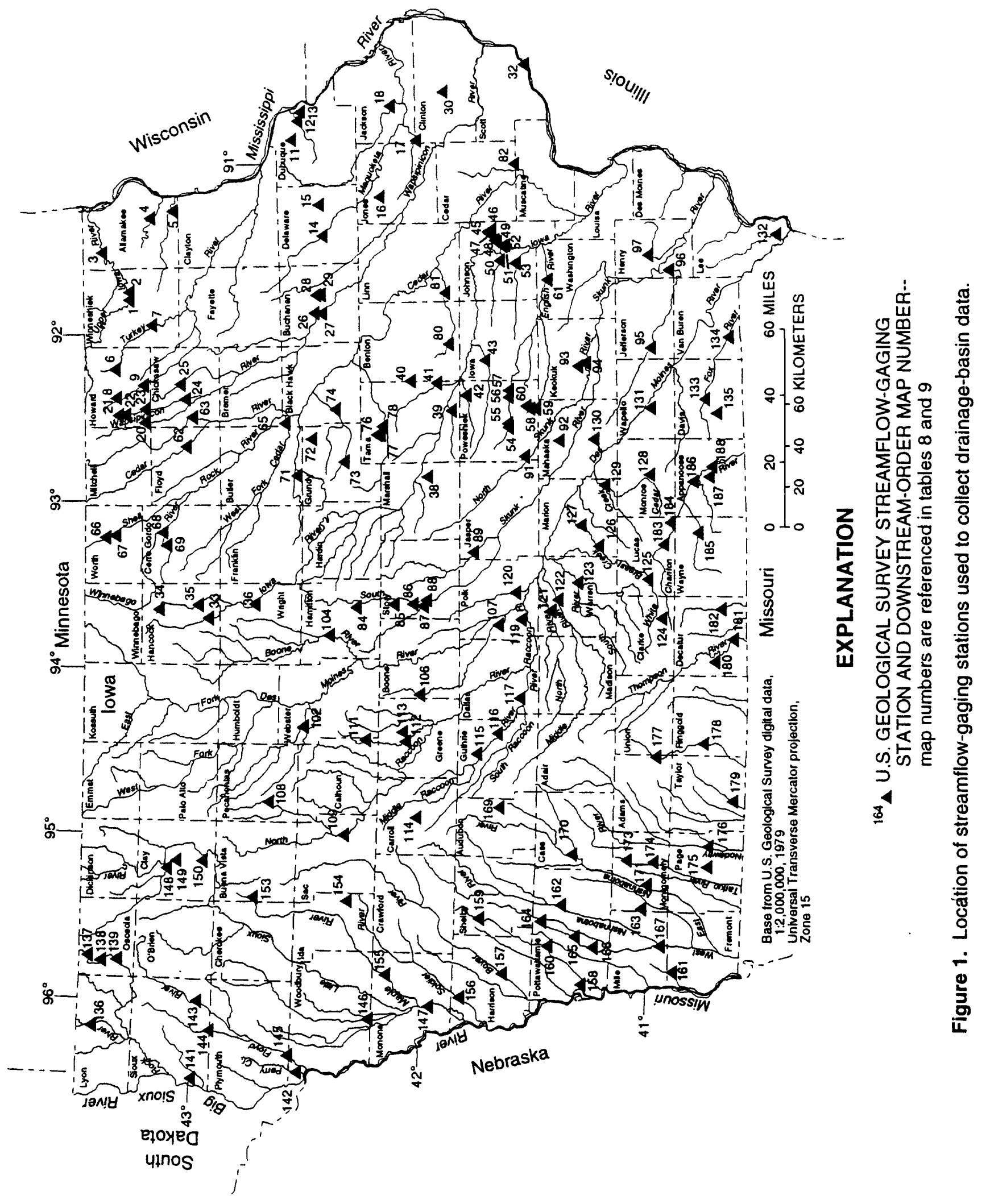




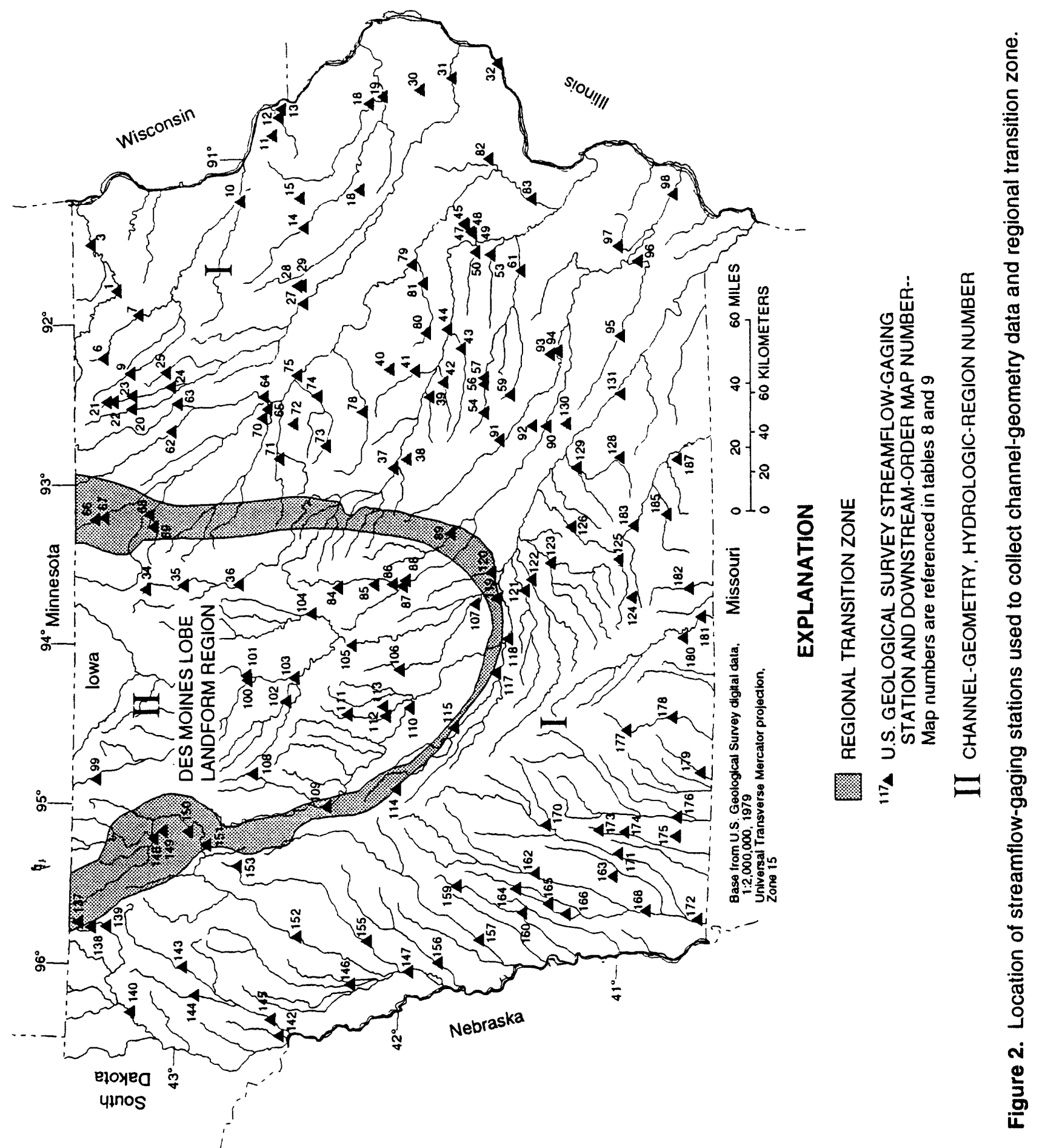


interval;

$\bar{x}$

is the mean of the logarithms (base 10) of the observed annual-peak discharges;

$k$

is the standardized Pearson Type-III deviate for a selected T-year recurrence interval and weighted skew coefficient; and

is the standard deviation of the logarithms (base 10) of the observed annual-peak discharges.

Results of the Pearson Type-III floodfrequency analyses are presented in table 8 (listed as method B17B, at end of this report) for the 188 streamflow-gaging stations analyzed using either the drainage-basin or channelgeometry flood-estimation techniques. Included in table 8 is information about the type of gage operated, the effective record length of the gage, whether a systematic or historical analysis was performed, the observed annual-peak discharge record (listed as flood period), and the maximum known flood-peak discharge and its recurrence interval. An example flood-frequency curve is shown in figure 3.

\section{DEVELOPMENT OF MULTIPLE-REGRESSION EQUATIONS}

Multiple linear-regression techniques were used to independently relate selected drainagebasin and channel-geometry characteristics to design-flood discharges having recurrence intervals of $2,5,10,25,50$, and 100 years. A general overview of the ordinary least-squares and weighted least-squares multiple linearregression techniques used to develop the equations is presented in the following two sections. Specific information on the multipleregression analyses for either flood-estimation method is presented in later sections entitled "Drainage-Basin Characteristic Equations" and "Channel-Geometry Characteristic Equations."

\section{Ordinary Least-Squares Regression}

Ordinary least-squares (OLS) multiple linear-regression techniques were used to develop the initial multiple-regression equations, or models, for both the drainagebasin and channel-geometry flood-estimation methods. In OLS regression, a design-flood discharge (termed the response variable) is estimated on the basis of one or more significant drainage-basin or channel-geometry characteristics (termed the explanatory variables) in which each observation is given an equal weight. The response variable is assumed to be a linear function of one or more of the explanatory variables. Logarithmic transformations (base 10) were performed for both the response and explanatory variables used in all of the OLS regression analyses. Data transformations were used to obtain a more constant variance of the residuals about the regression line and to linearize the relation between the response variable and explanatory variables. The general form of the OLS regression equations developed in these analyses is

$$
\begin{aligned}
& \log _{10}\left(Q_{T}\right)=\log _{10}(C)+b_{1} \log _{10}\left(X_{1}\right)+ \\
& b_{2} \log _{10}\left(X_{2}\right)+\ldots+b_{p} \log _{10}\left(X_{p}\right),
\end{aligned}
$$

where $Q_{T} \quad$ is the response variable, the estimated design-flood discharge, in cubic feet per second, for a selected T-year recurrence interval;

C is a constant;

$b_{i} \quad$ is the regression coefficient for the ith explanatory variable $(i \equiv$ $1, \ldots, p)$;

$X_{i} \quad$ is the value of the ith explanatory variable, a drainage-basin or channel-geometry characteristic $(\mathrm{i}=1, \ldots, \mathrm{p})$; and

$p$ is the total number of explanatory variables in the equation.

Equation 2, when untransformed, is algebraically equivalent to

$$
Q_{\mathrm{T}}=C\left(X_{1}\right)^{b} 1\left(X_{2}\right)^{b} 2 \ldots\left(X_{p}\right)^{b} p .
$$




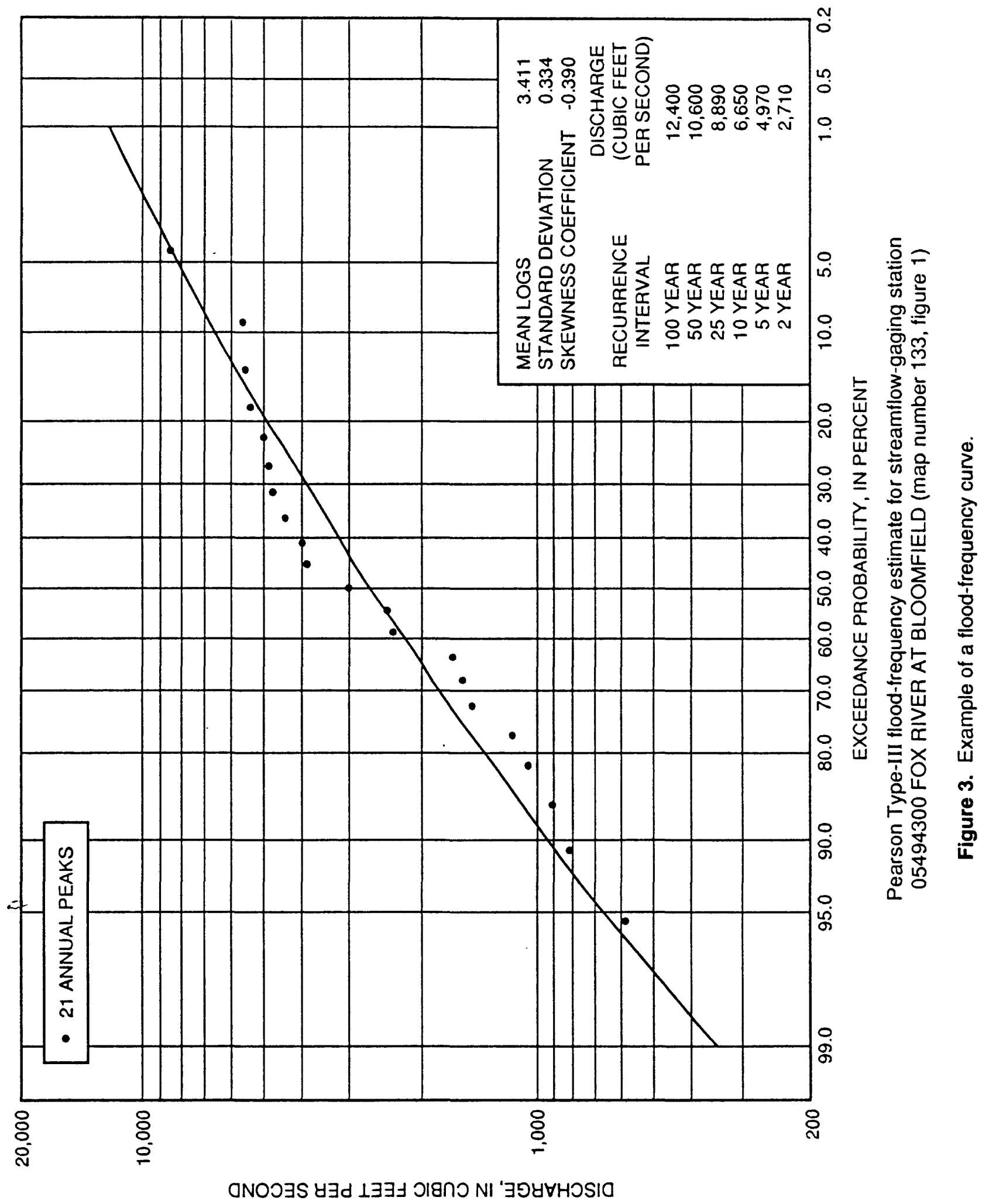


OLS regression analyses were performed using the Statit ${ }^{1}$ statistical procedures ALLREG and SREGRES (Statware, Inc., 1990, p. 6-10-6-27). Initial selections of significant explanatory variables for the OLS regression models were performed by using the ALLREG procedure. The ALLREG procedure uses an all-possible subsets regression to identify the best-possible combinations of explanatory variables on the basis of the Mallows' $C_{p}$ statistic (Mallows, 1973). The SREGRES procedure, based on stepwise-regression algorithms, then was used to perform an OLS regression analysis on each best-possible combination of explanatory variables. The final selection of explanatory variables was based on the following criteria as described by Koltun and Roberts (1990, p. 11):

1. The selection of explanatory variables, as well as the signs and magnitudes of their respective regression coefficients, need to be hydrologically valid in the context of flood runoff. This criterion takes precedence over all other criteria.

2. All explanatory variables should be statistically significant at the 95-percent confidence level.

3. The selection of explanatory variables, within the constraints of criteria 1 and 2 , should minimize the prediction error sum of squares [the PRESS statistic, an index of the prediction error associated with the regression equation (Allen, 1971; Montgomery and Peck, 1982)], maximize the coefficient of determination $\left(R^{2}\right.$, a measure of the proportion of the variation in the response variable accounted for by the regression equation), and minimize the standard error of estimate. Correlation between explanatory variables and the variance inflation factor (VIF) (Marquardt, 1970; Montgomery and Peck, 1982) was used to assess multicollinearity in the regression models.

\section{Weighted Least-Squares Regression}

A weighted least-squares (WLS) regression technique described by Tasker (1980 p. 11071109) was used to develop the final

\footnotetext{
${ }^{1}$ Use of brand names in this report is for identification purposes only and does not constitute endorsement by the U.S. Geological Survey.
}

multiple-regression equations for both the drainage-basin and channel-geometry floodestimation methods. WLS regression analyses improved $R^{2}$ values and standard errors of estimate obtained in the majority of the OLS regression analyses. Tasker $(1980$, p. 1107) reports that OLS regression assumes that the time-sampling variance in the responsevariable estimates (design-flood discharges) are the same for each gaging station used in the analysis (assumption of homoscedasticity). In hydrologic regression, this assumption usually is violated because the reliability of responsevariable estimates depends primarily on the length of the observed annual-peak discharge records. The error associated with response-variable estimates is inversely proportional to record length (Choquette, 1988, p. 16-17). WLS regression adjusts for the variation in the reliability of the responsevariable estimates by using a weighting function to account for differences in the lengths of observed annual-peak discharge records at gaging stations. The weighting function (Tasker, 1980, p. 1107) is based on theory and on analysis of residuals from the initial OLS regression equation. The weighting function assumes that the response variable (the design-flood discharge) is determined by fitting the logarithms (base 10) of the observed annual-peak discharges to a Pearson Type-III distribution.

The variance of the response variable, $Q_{\mathrm{T}}$, is estimated to determine the appropriate weight factors for the WLS regression analysis. To be effective, the weight factors should be inversely proportional to the variance of $Q_{\mathrm{T}}$. The variance of $Q_{T}$, for a selected T-year recurrence interval, can be partitioned into two components--the variance due to OLS regression-model error, $\mathrm{c}_{0}$, and the variance due to time-sampling error, $t_{i}$, which is related to the standard deviation and weighted skew coefficient of the logarithms of the observed annual-peak discharges and to the number of years of effective record length (Tasker, 1980, p, 1107-1109; Choquette, 1988, p. 16-17). The weight function has the form

$$
w_{i}=\frac{1}{\left(c_{0}+t_{l}\right)},
$$

where $w_{i} \quad$ is the weight factor for the ith gaging station used in the 
analysis.

The model error $\left(c_{0}\right)$ is estimated by

$$
c_{0}=\operatorname{maximum}\left[0 ;(S E)^{2}-c_{1}\left(\frac{1}{\overline{E R L}}\right)\right],
$$

where $S E$ is the standard error of the estimate from the OLS equation;

$c_{1}$ is a constant; and

$\overline{E R L}$ is the mean effective record length, in years, for all gaging stations used in each respective regression-model data set.

The time-sampling error $\left(t_{i}\right)$ is estimated by

$$
t_{i}=c_{1}\left(\frac{1}{E R L_{(i)}}\right),
$$

where $E R L_{(i)}$ is the effective record length, in years, for the ith gaging station used in each respective regression-model data set.

The constant, $c_{1}$, is related to the recurrence interval of the response variable and to the weighted skew coefficient $(g)$ of the observed annual-peak discharges. It is determined by

$$
c_{1}=\operatorname{maximum}\left[0 ; \vec{s}^{2}\left(1+\frac{\vec{k}^{2}}{2}\left(1+\frac{3}{4} \bar{g}^{2}\right)+\overrightarrow{k g}\right)\right],
$$

$$
\begin{array}{cl}
\text { where } \bar{s} & \begin{array}{l}
\text { is the mean standard deviation of } \\
\text { the logarithms (base 10) of the } \\
\text { observed annual-peak dis- } \\
\text { charges; }
\end{array} \\
\bar{k} \quad & \begin{array}{l}
\text { is the mean standardized } \\
\text { Pearson Type-III deviate for } \\
\text { selected T-year recurrence }
\end{array} \\
\text { interval and mean weighted } \\
\text { skew coefficient } \bar{g} \text { (IACWD, 1982, } \\
\text { p. 3-1 - 3-27); and } \\
\text { is the mean weighted skew } \\
\text { coefficient of the logarithms (base } \\
\text { 10) of the observed annual-peak } \\
\text { discharges (IACWD, 1982, p. } \\
\text { 12-15). }
\end{array}
$$

The values $\bar{s}$ and $\bar{g}$ are statewide estimates determined by the averages of the 188 streamflow-gaging stations analyzed using either the drainage-basin or channel-geometry flood-estimation techniques. These estimation methods are based on the assumption that $\bar{s}$ and $\bar{g}$ are approximately constant for all the gaging stations in the State.

The effective record length (ERL) of a gaging station is based on an empirical analysis made by Gary D. Tasker (U.S. Geological Survey, written commun., March 1992) of results reported in Tasker and Thomas (1978) and Stedinger and Cohn (1986). It is determined by

$$
E R L=L S+(H S T-L S) a,
$$

where $L S$ is the systematic record length of a gaging station, in years, the number of water years during which the gaging station was operated;

$H S T$ is the historic record length of a gaging station, in years, as used in a Pearson Type-III historical flood-frequency analysis; if a systematic flood-frequency analysis was performed, $H S T=$ $L S$; if $(H S T-L S)>200$, set $(H S T-L S)=200 ;$ and

$$
a=0.55-0.1\left[\log _{e}\left(\frac{p h}{(1-p h)}\right)\right] \text {. }
$$

In the last equation, $p h=1.0-(n p / H S T)$, and $n p$ is the number of historic and extremely large discharge (high-outlier) peaks.

The $E R L$ used in the weighted least-squares regression analyses for each gaging station is listed in table 8 (at end of this report).

\section{ESTIMATING DESIGN-FLOOD DISCHARGES USING DRAINAGE-BASIN CHARACTERISTICS}

The drainage-basin flood-estimation method uses selected drainage-basin characteristics to estimate the magnitude and frequency of floods for stream sites in Iowa. Multiple-regression equations were developed by relating significant drainage-basin characteristics to Pearson Type-III, design-flood discharges for 164 
streamflow-gaging stations in Iowa (fig. 1). Drainage-basin characteristics were quantified using a GIS procedure to process topographic maps and digital cartographic data. An overview of the GIS procedure is provided in the following section.

\section{Geographic-Information-System Procedure}

The GIS procedure developed by the U.S. Geological Survey (USGS) quantifies for each drainage basin the 26 basin characteristics listed in Appendix A (at end of this report). These characteristics were selected for the GIS procedure on the basis of their hypothesized applicability in flood-estimation analysis and their general acceptability as measurements of drainage-basin morphology and climate. Techniques for making manual measurements of selected drainage-basin characteristics from topographic maps are outlined in Appendix B (at end of this report). The GIS procedure uses ARC/INFO computer software and other software developed specifically to integrate with ARC/INFO (Majure and Soenksen, 1991; Eash, 1993).

The GIS procedure entails four main steps: (1) creation of four GIS digital maps (ARC/INFO coverages) from three cartographic data sources, (2) assignment of attribute information to three of the four GIS digital maps, (3) quantification of 24 morphologic basin characteristics from the four GIS digital maps, and (4) quantification of two climatic basin characteristics from two precipitation data sources.

The first step creates four GIS digital maps representing selected aspects of a drainage basin. Examples of these maps are shown in figure 4. The drainage-divide digital map (fig. $4 A$ ) is created by delineating the surface-water drainage-divide boundary for a streamflowgaging station on 1:250,000-scale U.S. Defense Mapping Agency (DMA) topographic maps. This drainage-divide delineation is manually digitized into a polygon digital map using GIS software. If noncontributing drainage areas are identified within the drainage-divide boundary, then each noncontributing drainage area also is delineated and digitized.
The drainage-network digital map (fig. $4 B$ ) is created by extracting the drainage network for the basin from 1:100,000-scale USGS digital line graph (DLG) data. The extraction process uses GIS software to select and append together the DLG data contained within the drainage-divide polygon.

The elevation-contour digital map (fig. $4 C$ ) is created from 1:250,000-scale DMA digital elevation model (DEM) data that are referenced to sea level (in meters). GIS software is used to convert the DEM data to a lattice file of point elevations for an area slightly larger than the drainage-divide polygon. This lattice file of point elevations is contoured with a 12-meter (39.372-ft) or smaller contour interval using ARC/INFO software. The contour interval is chosen to provide at least five contours for each drainage basin. GIS software selects the contours contained within the drainage-divide polygon to create the elevation-contour digital map. Elevation contours then are converted to units of feet.

The basin-length digital map (fig. $4 D$ ) is created by delineating and digitizing the basin length from 1:250,000-scale DMA topographic maps. The basin length characteristic is delineated by first identifying the main channel for the drainage basin on 1:100,000-scale topographic maps. The main channel is identified by starting at the basin outlet and proceeding upstream, repetitively selecting the channel that drains the greater area at each stream junction. The most upstream channel is extended to the drainage-divide boundary defined for the drainage-divide digital map. This main channel identified on 1:100,000-scale topographic maps is used to define the main channel on 1:250,000-scale topographic maps. The basin length is centered along the main-channel, flood-plain valley from basin outlet to basin divide and digitized with as straight a line as possible from the 1:250,000-scale maps. When comparing the basin length shown in figure $4 D$ to those stream segments corresponding to the main channel in figure $4 B$, it can be seen that the basin length does not include all the sinuosity of the stream segments.

The second step assigns attributes to specific polygon, line-segment, and point 


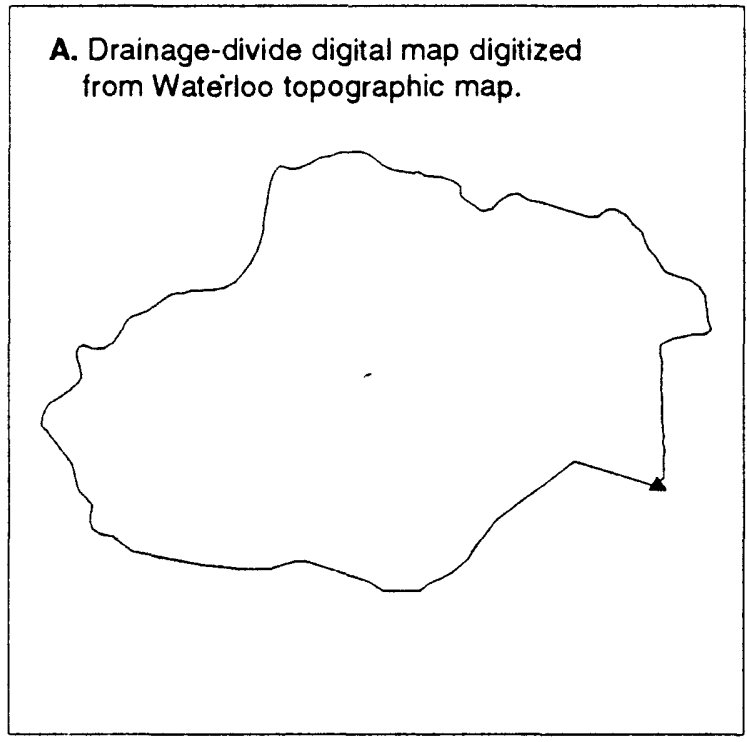

Base from U.S. Defense Mapping Agency, $1: 250,000,1976$

Universal Transverse Mercator projection Zone 15
B. Drainage-network digital map extracted
from Marshalltown-West digital line
graph data, with stream-order numbers.

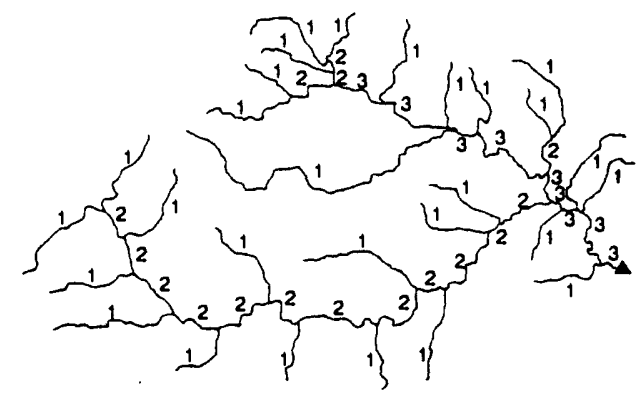

\section{Base from U.S. Geological Survey digital} data, $1: 100,000,1984$

Universal Transverse Mercator projection. Zone 15

\section{Basin-length digital map digitized} from Waterloo topographic map.

Waterloo-East digital elevation model, sea-level data, with contour intervals at 39.372 feet.

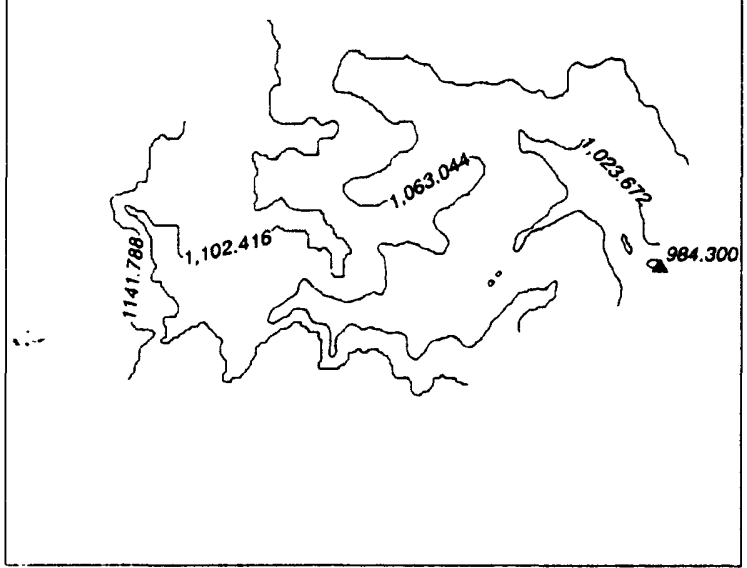

Base from U.S. Defense Mapping Agency. $1: 250,000,1976$

Universal Transverse Mercator projection, Zone 15

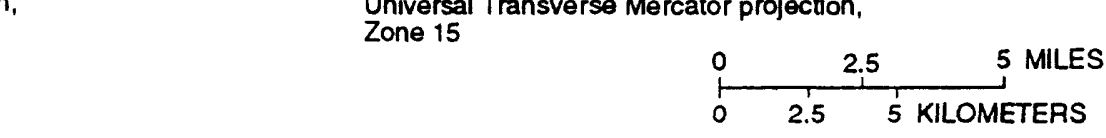

\section{EXPLANATION}

- STREAMFLOW-GAGING STATION

Figure 4. Four geographic-information-system maps that constitute a digital representation of selected aspects of a drainage basin. 
features in the first three of the four GIS digital maps shown in figure 4 . As a prerequisite, the digital maps are edited to ensure that drainage-divide boundaries, stream segments, and the basin-length line segments are connected properly. If noncontributing drainage areas are identified, they are assigned attributes with separate polygon designations so that the basin-characteristic programs can distinguish between contributing and noncontributing areas. Each line segment in the drainage-network digital map is assigned a Strahler stream-order number (Strahler, 1952) and a code indicating whether the line segment represents part of the main channel or a secondary channel. Specific GIS programs have been developed to assign the proper streamorder number to each line segment and to code those line segments representing the main channel. Figure $4 B$ shows the Strahler stream-order numbers for streams in the Black Hawk Creek at Grundy Center (station number 05463090; map number 73, fig. 1) drainage basin. A description on how to order streams using Strahler's method is included in Appendix $B$ (at end of this report).

The line segments in the elevation-contour digital map were assigned elevations from the processing of the DEM data. Line segments overlain by noncontributing drainage-area polygons are assigned attributes designating noncontributing contour segments. Two point attributes are added to the elevation-contour digital map to represent the maximum and minimum elevations of the drainage basin. The maximum basin elevation is defined from the highest DEM-generated contour elevation within the contributing drainage area. The minimum basin elevation is defined at the basin outlet as an interpolated value between the first elevation contour crossing the main channel upstream of the basin outlet and the first elevation contour crossing the main channel downstream of the basin outlet.

The third step uses the four GIS digital maps shown in figure 4 and a set of programs developed by the USGS (Majure and Soenksen, 1991) to quantify the 24 morphologic basin characteristics listed in Appendix A (at end of this report). These basin characteristics include selected measurements of area, length, shape, and topographic relief that define selected aspects of basin morphology, and several channel characteristics. The programs access the information automatically maintained by the GIS for each of the four digital maps, such as the length of line segments and the area of polygons, as well as the previously described attribute information assigned to the polygon, line-segment, and point features of three of the four GIS digital maps. The GIS programs then use this information to automatically quantify the 24 morphologic basin characteristics.

The fourth step uses a software program developed to quantify the remaining two basin characteristics listed in Appendix A (at end of this report). These two climatic characteristics are quantified using GIS digital maps representing the distributions of mean annual precipitation and 2-year, 24-hour precipitation intensity for the area contributing to all surface-water drainage in Iowa. This area includes a portion of southern Minnesota. The mean annual precipitation digital map was digitized from a contour map for Iowa, supplied by the Iowa Department of Agriculture and Land Stewardship, State Climatology Office (Des Moines), and from a contour map for Minnesota (Baker and Kuehnast, 1978). The 2-year, 24-hour precipitation intensity digital map was digitized from a contour map for Iowa (Waite, 1988, p. 31) and interpolated contours for southern Minnesota that were digitized from a United States contour map (Hershfield, 1961, p. 95). The digital map representing the distribution of 2-year, 24-hour precipitation intensity for Iowa and southern Minnesota is shown in figure 5 . The weighted average for each climatic characteristic is computed for a drainage basin by calculating the mean of the area-weighted precipitation values that are within the drainage-divide polygon.

Of the 26 drainage-basin characteristics listed in Appendix A, 12 are referred to as primary drainage-basin characteristics because they constitute specific GIS procedure or manual topographic-map measurements. They are listed under headings containing the word "measurement." The remaining characteristics are calculated from the primary drainage-basin characteristics; they are listed in Appendix A under headings containing the word "computation." Each drainage-basin characteristic listed in Appendix $\mathrm{A}$ is footnoted with a 


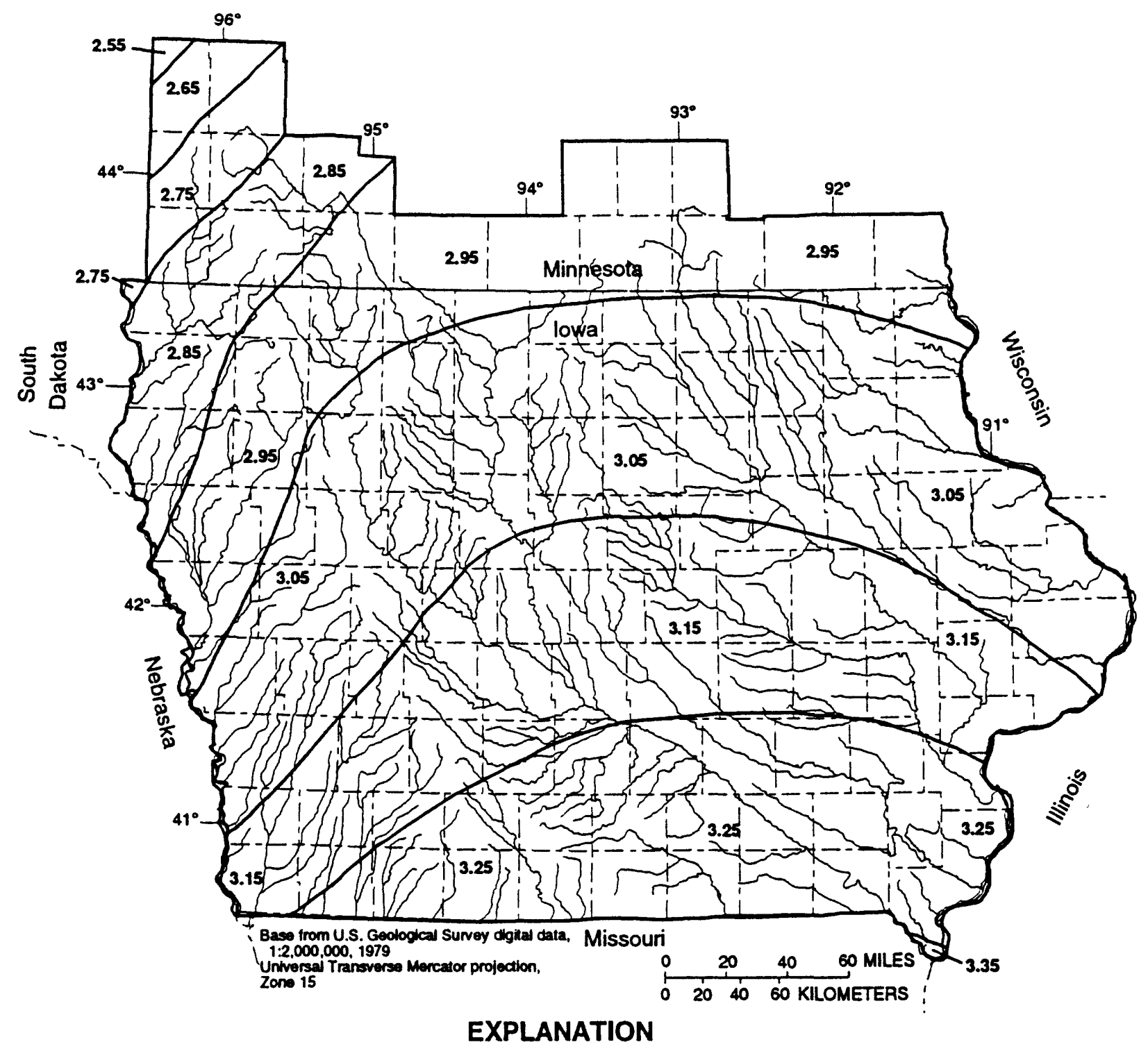

3.15 AREA OF EQUAL 2-YEAR, 24-HOUR PRECIPITATION

INTENSITY-Number is precipitation intensity, in inches

Figure 5. Distribution of 2-year, 24-hour precipitation intensity for lowa and southern Minnesota.

reference and the cartographic data source used for both GIS procedure and manual measurements.

\section{Verification of Drainage-Basin Characteristics}

To verify that the drainage-basin characteristics quantified using the GIS procedure are valid, manual topographic-map measurements of selected drainage-basin characteristics were made for 12 of the streamflow-gaging stations used in the drainage-basin flood-estimation method. These comparison measurements were made for those primary drainage-basin characteristics identified as being significantly related to flood runoff in the multiple-regression equations presented in the following section entitled "Drainage-Basin Characteristic Equations." Comparison measurements were made from topographic maps of the same scales as were used in the GIS procedure. The results of the comparisons are shown in table 1. 
Table 1. Comparisons of manual measurements and geographic-information-system-procedure measurements of selected drainage-basin characteristics at selected streamflow-gaging stations

[TDA, total drainage area, in square miles; $B P$, basin perimeter, in miles; $B R$, basin relief, in feet; $F O S$, number of first-order streams; $T T F, 2$-year, 24-hour precipitation intensity, in inches; $M A N$, manual measurement; GIS, geographic-information-system procedure; \% $D I F F$, percentage difference between MAN and GIS]

\begin{tabular}{|c|c|c|c|c|c|c|}
\hline \multirow{2}{*}{$\begin{array}{l}\text { Station } \\
\text { number }\end{array}$} & \multirow{2}{*}{$\begin{array}{l}\text { Measure- } \\
\text { ment - } \\
\text { technique }\end{array}$} & \multicolumn{5}{|c|}{ Selected drainage-basin characteristics } \\
\hline & & $T D A^{1}$ & $B P$ & $B R$ & FOS & $T T F$ \\
\hline \multirow[t]{3}{*}{05411600} & $M A N$ & 177 & 73.3 & 297 & 84 & 3.05 \\
\hline & GIS & 178 & 73.9 & 274 & 84 & 3.05 \\
\hline & $\% D I F F$ & +0.6 & +0.8 & -7.7 & 0 & 0 \\
\hline \multirow[t]{3}{*}{05414450} & $M A N$ & 21.6 & 21.9 & 444 & 10 & 3.05 \\
\hline & GIS & 22.3 & 21.3 & 394 & 10 & 3.05 \\
\hline & $\% D I F F$ & +3.2 & -2.7 & -11.3 & 0 & 0 \\
\hline \multirow[t]{3}{*}{05414600} & $M A N$ & 1.54 & 5.32 & 280 & 1 & 3.05 \\
\hline & GIS & 1.53 & 5.97 & 291 & 1 & 3.05 \\
\hline & $\% D I F F$ & -0.6 & +12.2 & +3.9 & 0 & 0 \\
\hline \multirow[t]{3}{*}{05462750} & $M A N$ & 11.6 & 15.0 & 160 & 6 & 3.05 \\
\hline & GIS & 11.9 & 15.5 & 129 & 6 & 3.05 \\
\hline & $\% D I F F$ & +2.6 & +3.3 & -19.4 & 0 & 0 \\
\hline \multirow[t]{3}{*}{05463090} & $M A N$ & 56.9 & 33.5 & 181 & 28 & 3.15 \\
\hline & GIS & 57.0 & 33.1 & 160 & 28 & 3.15 \\
\hline & $\% D I F F$ & +0.2 & -1.2 & -11.6 & 0 & 0 \\
\hline \multirow[t]{3}{*}{05470500} & $M A N$ & 204 & 69.8 & 318 & 60 & 3.15 \\
\hline & GIS & 208 & 67.7 & 292 & 51 & 3.15 \\
\hline & $\% D I F F$ & +2.0 & -3.0 & -8.2 & -15.0 & 0 \\
\hline \multirow[t]{3}{*}{05481000} & $M A N$ & 844 & 139 & 303 & 152 & 3.05 \\
\hline & GIS & 852 & 139 & 300 & 155 & 3.05 \\
\hline & $\% D I F F$ & +0.9 & 0 & -1.0 & +2.0 & 0 \\
\hline \multirow[t]{3}{*}{05489490} & $M A N$ & 22.9 & 24.8 & 280 & 10 & 3.25 \\
\hline & GIS & 22.2 & 26.2 & 263 & 10 & 3.25 \\
\hline & $\% D I F F$ & -3.1 & +5.6 & -6.1 & 0 & 0 \\
\hline \multirow[t]{3}{*}{06483430} & $M A N$ & 29.9 & 28.8 & 198 & 12 & 2.85 \\
\hline & GIS & 30.0 & 28.9 & 182 & 12 & 2.85 \\
\hline & $\% D I F F$ & +0.3 & +0.3 & -8.1 & 0 & 0 \\
\hline \multirow[t]{3}{*}{06609500} & $M A N$ & 871 & 206 & 582 & 477 & 3.05 \\
\hline & GIS & 869 & 210 & 550 & 475 & 3.05 \\
\hline & $\% D I F F$ & -0.2 & +1.9 & -5.5 & -0.4 & 0 \\
\hline
\end{tabular}


Table 1. Comparisons of manual measurements and geographic-information-system-procedure measurements of selected drainage-basin characteristics at selected streamflow-gaging stations--Continued

\begin{tabular}{llccccc}
\hline \multirow{2}{*}{$\begin{array}{l}\text { Station } \\
\text { number }\end{array}$} & $\begin{array}{l}\text { Measure- } \\
\text { ment } \\
\text { technique }\end{array}$ & $T D A^{1}$ & $B P$ & $B R$ & $F O S$ & $T T F$ \\
\cline { 3 - 7 } 06807780 & $M A N$ & 42.7 & 47.4 & 268 & 18 & 3.05 \\
& GIS & 42.8 & 48.8 & 280 & 19 & 3.05 \\
& $\% D I F F$ & +0.2 & +3.0 & +4.5 & +5.6 & 0 \\
06903400 & $M A N$ & 182 & 79.0 & 224 & 80 & 3.25 \\
& GIS & 184 & 79.6 & 256 & 80 & 3.25 \\
& $\% D I F F$ & +1.1 & +0.8 & +14.3 & 0 & 0 \\
WILCOXON SIGNED-RANKS & & & & & \\
TEST STATISTIC & & -1.726 & -1.334 & -1.843 & -0.365 & NO TEST $^{3}$ \\
p-VALUE STATISTIC & 0.0844 & 0.1823 & 0.0653 & 0.7150 & \\
\hline
\end{tabular}

${ }^{1}$ Manual TDA measurements are streamflow-gaging-station drainage areas published by the U.S. Geological Survey in annual streamflow reports. Noncontributing drainage areas (NCDA) are not listed because none were identified for these drainage basins.

${ }^{2}$ Using a 95-percent level of significance, the T-value statistic $=2.2010$ (Iman and Conover, 1983, p. 438).

${ }^{3}$ All values for $\% D I F F=0$.

Comparison measurements for total drainage area (TDA) indicate that the GIS procedure was within about 1 percent of the drainage areas published by the USGS in annual streamflow reports for 8 of the 12 selected gaging stations. This comparison indicates that delineations of drainage areas used in the GIS procedure, made from 1:250,000-scale topographic maps, were generally valid. The Wilcoxon signed-ranks test was applied to four of the five drainage-basin characteristics listed in table 1 using STATIT procedure SGNRNK (Statware, Inc., 1990, p. 3-25 - 3-26). Results (table 1) indicate that GIS procedure measurements of total drainage area, basin perimeter (BP), basin relief (BR), and number of first-order streams (FOS) were not significantly different from manual topographic-map measurements at the 95-percent level of significance. The greater variation in measurement comparisons of basin relief are believed to be due to limitations in the 1:250,000-scale DEM data. Results of the comparison tests (table 1) indicate that GIS procedure measurements are generally valid for the primary drainage-basin characteristics used in the regression equations presented in the following section.

Basin slope (BS) is another drainage-basin characteristic that was quantified using DEM data. It is hypothesized that basin slope may have a significant effect on surface-water runoff. Basin slope was indicated as being a significant characteristic in a few of the initial multiple-regression analyses. Comparison measurements indicated that the GIS procedure greatly underestimated basin slope. Measurement differences for basin slope were between minus 9 and 66 percent, with an average 
underestimation of 40 percent for the 10 drainage basins tested (Eash, 1993, p. 180-181). For this reason, the basin-slope characteristic was deleted from the drainage-basin characteristics data set during the initial multiple-regression analyses. Basin-slope comparisons appear to indicate that the 1:250,000-scale DEM data used to create the elevation-contour digital maps are not capable of reproducing all the sinuosity of the elevation contours depicted on the 1:250,000-scale DMA topographic maps. The elevation contours generated using the GIS procedure are much more generalized than the topographic-map contours; thus, the total length of the elevation contours are undermeasured when using the "contour-band" method of calculating basin slope (BS) (Appendix A). A comparison of the elevation contours shown in figure $4 C$ for the Black Hawk Creek at Grundy Center (station number 05463090; map number 73, fig. 1) drainage basin to those depicted on the DMA 1:250,000-scale Waterloo topographic map showed a significant difference in the sinuosity of the elevation contours depicted.

\section{Drainage-Basin Characteristic Equations}

The 26 drainage-basin characteristics listed in Appendix A were quantified for 164 streamflow-gaging stations (fig. 1) and investigated as potential explanatory variables in the development of multiple-regression equations for the estimation of design-flood discharges. Because of the previously described problems concerning measurement verification of basin slope and because of the difficulty associated with manual measurements of total stream length, six basin characteristics were deleted from the regression data set. The excluded characteristics were basin slope $(B S)$, total stream length (TSL), stream density $(S D)$, constant of channel maintenance (CCM), ruggedness number $(R N)$, and slope ratio $(S R)$.

Several other drainage-basin characteristics also were deleted from the data set because of multicollinearity. Multicollinearity is the condition where at least one explanatory variable is closely related to (that is, not independent of) one or more other explanatory variables. Regression models that include variables with multicollinearity may be unreliable because coefficients in the models may be unstable. Output from the ALLREG analysis and a correlation matrix of Pearson product-moment correlation coefficients were used as guides in identifying the variables with multicollinearity. The hydrologic validity of variables with multicollinearity in the context of flood runoff was the principal criterion used in determining which drainage-basin characteristics were deleted from the data set. Upon completion of the ALLREG analyses, any remaining multicollinearity problems were identified with the SREGRES procedure by checking each explanatory variable for variance inflation factors greater than 10 .

Statewide flood-estimation equations were developed from analyses of the drainage-basin characteristics using the ordinary least-squares and weighted least-squares multiple-regression techniques - previously described. The best equations developed in terms of PRESS statistics, coefficients of determination, and standard errors of estimate are listed in table 2. The characteristics identified as most significant in the drainage-basin equations are contributing drainage area $(C D A)$, relative relief $(R R)$, drainage frequency $(D F)$, and 2-year, 24-hour precipitation intensity (TTF). Table 9 (at end of this report) lists these significant drainage-basin characteristics, as quantified by the GIS procedure, for 164 streamflow-gaging stations in Iowa.

Three of the four characteristics listed in the drainage-basin equations (table 2) are calculated from primary drainage-basin characteristics. The drainage-basin equations are comprised of six primary drainage-basin characteristics. Contributing drainage area $(C D A)$ is a measure of the total area that contributes to surface-water runoff at the basin outlet. The primary drainage-basin characteristics used to calculate contributing drainage area are total drainage area (TDA) and noncontributing drainage area (NCDA). Relative relief $(R R)$ is a ratio of two primary drainage-basin characteristics, basin relief $(B R)$ and basin perimeter $(B P)$. Drainage frequency $(D F)$ is a measure of the average number of first-order streams per unit area and is an indication of the spacing of the drainage network. The primary drainage-basin characteristics used to calculate drainage 
Table 2. Statewide drainage-basin characteristic equations for estimating design-flood discharges in Iowa

$[Q$, peak discharge, in cubic feet per second, for a given recurrence interval, in years; $C D A$, contributing drainage area, in square miles; $R R$, relative relief, in feet per mile; $D F$, drainage frequency, in number of first-order streams per square mile; TTF, 2-year, 24-hour precipitation intensity, in inches]

\begin{tabular}{|c|c|c|c|c|}
\hline \multirow[b]{2}{*}{ Estimation equation } & \multicolumn{2}{|c|}{$\begin{array}{c}\text { Standard } \\
\text { error of estimate }\end{array}$} & \multirow{2}{*}{$\begin{array}{c}\text { Average } \\
\text { standard error } \\
\text { of prediction } \\
\frac{\text { tpercent) }}{t}\end{array}$} & \multirow{2}{*}{$\begin{array}{r}\text { Average } \\
\text { equivalent } \\
\text { years of } \\
\text { record }\end{array}$} \\
\hline & $\log _{10}$ & Percent & & \\
\hline
\end{tabular}

Number of streamflow-gaging stations $=164$

\begin{tabular}{|c|c|c|c|c|}
\hline$Q_{2}=53.1 C D A^{0.799} R R^{0.643} D F^{0.381}(T T F-2.5)^{1.36}$ & 0.171 & 41.0 & 42.2 & 3.9 \\
\hline$Q_{5}=98.8 C D A^{0.755} R R^{0.652} D F^{0.380}(T T F-2.5)^{0.985}$ & .156 & 37.2 & 38.6 & 5.4 \\
\hline$Q_{10}=136 C D A^{0.733} R R^{0.654} D F^{0.384}(T T F-2.5)^{0.801}$ & .160 & 38.2 & 39.8 & 6.5 \\
\hline$Q_{25}=188 C D A^{0.709} R R^{0.655} D F^{0.393}(T T F-2.5)^{0.610}$ & .172 & 41.3 & 43.2 & 7.8 \\
\hline$Q_{50}=231 C D A^{0.694} R R^{0.656} D F^{0.401}(T T F-2.5)^{0.491}$ & .185 & 44.5 & 46.5 & 9.5 \\
\hline$Q_{100}=277 C D A^{0.681} R R^{0.656} D F^{0.409}(T T F-2.5)^{0.389}$ & .198 & 48.0 & 50.2 & 11.5 \\
\hline
\end{tabular}

Note: Basin characteristics are map-scale dependent. See Appendix A and Appendix B for basin-characteristic descriptions, computations, and scales of maps to use for manual measurements.

frequency are the number of first-order streams (FOS) and contributing drainage area (CDA). The value of FOS is determined by using Strahler's method of ordering streams (Strahler, 1952). A description of Strahler's stream-ordering method is included in Appendix B. The 2-year, 24-hour precipitation intensity $(T T F)$ is a primary drainage-basincharacteristic measurement of the maximum 24-hour precipitation expected to be exceeded on the average once every 2 years.

Additional information pertaining to the characteristics used in the drainage-basin equations (table 2) is included in Appendix A. Techniques on how to make manual measurements from topographic maps for the primary drainage-basin characteristics used in the equations are outlined in Appendix B. Several of the primary drainage-basin characteristics are map-scale dependent. Use of maps of scales other than the scales used to develop the equations may produce results that do not conform to the range of estimation accuracies listed for the equations in table 2. The scale of map to use for manual measurements of each primary drainage-basin characteristic is outlined in Appendix A and Appendix B.

Examination of residuals, the difference between the Pearson Type-III and multipleregression estimates of peak discharge for the drainage-basin equations, indicated no evidence of geographic bias. The drainage-basin equations thus were determined to be independent of hydrologic regionalization within the State. 
The drainage-basin flood-estimation method developed in this study is similar to the regional flood-estimation method developed by Lara (1987) because both methods estimate flood discharges on the basis of morphologic relations. While the standard errors of estimate appear to be higher for the drainage-basin equations than for Lara's equations (Lara, 1987, p. 28), a direct comparison cannot be made because of the different methodologies used to develop the equations. Lara's method is based on the physiography of broad geographic landform regions defined for the State, whereas the drainage-basin method presented in this report is based on specific measurements of basin morphology. The drainage-basin equations are independent of hydrologic regionalization. The application of regional equations often requires that subjective judgments be made concerning basin anomalies and the weighting of regional discharge estimates. This subjectivity may introduce additional unmeasured error to the estimation accuracy of the regional discharge estimates. The drainage-basin regression equations presented in this report provide a flood-estimation method that minimizes the subjectivity in its application to the ability of the user to measure the characteristics.

\section{Example of Equation Use-- Example 1}

Example 1.--An application of the drainagebasin flood-estimation method can be illustrated by using the equation (listed in table 2) to estimate the 100-year peak discharge for the discontinued Black Hawk Creek at Grundy Center crest-stage gaging station (station number 05463090; map number 73, fig. 1), located in Grundy County, at a bridge crossing on State Highway 14, at the north edge of Grundy Center, in the NW1/4, sec. 7, T. 87 N., R. $16 \mathrm{~W}$. Differences between manually computed values (table 1) and values computed using the GIS procedure (tables 1 and 9) are due to differences in applying the techniques.

Step 1. The characteristics used in the drainage-basin equation (table 2) are contributing drainage area $(C D A)$, relative relief $(R R)$, drainage frequency $(D F)$, and 2-year, 24-hour precipitation intensity (TTF). The primary drainage-basin characteristics used in this equation are total drainage area (TDA), noncontributing drainage area (NCDA), basin relief $(B R)$, basin perimeter $(B P)$, number of first-order streams ( $F O S$ ), and 2-year, 24-hour precipitation intensity $(T T F)$. These primary drainage-basin characteristic measurements and the scale of maps to use for each manual measurement are described in Appendix $A$ and Appendix B.

Step 2. The topographic maps used to delineate the drainage-divide boundary for this gaging station are the DMA 1:250,000-scale Waterloo topographic map and the USGS 1:100,000-scale Grundy County map. Figure $4 A$ shows the drainage-divide boundary that was delineated for this gaging station on the 1:250,000-scale map. Contributing drainage area $(C D A)$ is calculated from the primary drainage-basin characteristics total drainage area (TDA) and noncontributing drainage area (NCDA). The total drainage area published for this gaging station in the annual streamflow reports of the U.S. Geological Survey is $56.9 \mathrm{mi}^{2}$ (table 9). Inspection of the 1:100,000-scale map does not show any noncontributing drainage areas within the drainage-divide boundary of this basin. The contributing drainage area $(C D A)$ is calculated as

$$
\begin{aligned}
C D A & =T D A-N C D A, \\
& =56.9-0, \\
& =56.9 \mathrm{mi}^{2} .
\end{aligned}
$$

Step 3. Relative relief $(R R)$ is calculated from the primary drainage-basin characteristics basin relief $(B R)$ and basin perimeter $(B P)$. The difference between the highest elevation contour and the lowest interpolated elevation in the basin measured from the 1:250,000-scale topographic map gives a basin relief of $181 \mathrm{ft}$ (table 1). Figure $4 C$ shows an approximate representation of the topography for this drainage basin. The drainage-divide boundary delineated on the 1:250,000-scale topographic map (fig. $4 A$ ) is used to measure the basin perimeter, which is $33.5 \mathrm{mi}$ (table 1 ). Relative relief $(R R)$ is calculated as 


$$
\begin{aligned}
R R & =\frac{B R}{B P}, \\
& =\frac{181}{33.5}, \\
& =5.40 \mathrm{ft} / \mathrm{mi} .
\end{aligned}
$$

Step 4. Drainage frequency $(D F)$ is calculated from the primary drainage-basin characteristics number of first-order streams (FOS) and contributing drainage area (CDA). A total of 28 first-order streams are counted within the drainage-divide delineation for this gaging station on the 1:100,000-scale topographic map (table 1). These first-order streams are shown in figure $4 B$. Drainage frequency $(D F)$ is calculated as

$$
\begin{aligned}
D F & =\frac{F O S}{C D A}, \\
& =\frac{28}{56.9}, \\
& =0.492 \text { first-order streams } / \mathrm{mi}^{2} .
\end{aligned}
$$

Step 5. The 2-year, 24-hour precipitation intensity $(T T F)$ for the drainage basin is determined from figure 5 . Because the drainage-divide boundary for this gaging station is completely within the polygon labeled as 3.15 in., the 2-year, 24-hour precipitation intensity is given a value of 3.15 in. (table 1 ).

Step 6. The 100-year flood estimate using the drainage-basin equation (table 2) is calculated as

$$
\begin{aligned}
Q_{100} & =277(C D A)^{0.681}(R R)^{0.656}(\mathrm{DF})^{0.409}(T T F-2.5)^{0.389} \\
& =277(56.9)^{0.681}(5.40)^{0.656}(0.492)^{0.409}(3.15-2.5)^{0.389} \\
& =8,310 \mathrm{ft}^{3} / \mathrm{s} .
\end{aligned}
$$

Discharge estimates listed in this report are rounded to three significant figures. The difference between the above estimate of $8,310 \mathrm{ft}^{3} / \mathrm{s}$ and the estimate of $7,740 \mathrm{ft}^{3} / \mathrm{s}$ listed in table 8 (method GISDB) is due to measurement differences between manual measurement and GIS procedure techniques (table 1).

\section{ESTIMATING DESIGN-FLOOD DISCHARGES USING CHANNEL-GEOMETRY CHARACTERISTICS}

The channel-geometry flood-estimation method uses selected channel-geometry characteristics to estimate the magnitude and frequency of floods for stream sites in Iowa. The channel-geometry method is based on measurements of channel morphology, which are assumed to be a function of streamflow discharges and sediment-load transport. Multiple-regression equations were developed by relating significant channel-geometry characteristics to Pearson Type-III, design-flood discharges for 157 streamflow-gaging stations in Iowa (fig. 2).

\section{Channel-Geometry Data Collection}

The channel-geometry parameters that were measured for each of the gaging stations are as follows:

$A C W$ - average width of the active channel, in feet;

$A C D$ - average depth of the active channel, in feet;

$B F W$ - average width of the bankfull channel, in feet;

$B F D$ - average depth of the bankfull channel, in feet;

$S C_{b d}$ - silt-clay content of channel-bed material, in percent;

$S C_{\text {lbk }}$ - silt-clay content of left channel-bank material, in percent;

$S C_{\text {rbk }}$ - silt-clay content of right channel-bank material, in percent;

$D_{50}$ - diameter size of channel-bed particles for which the total weight of all particles with diameters greater than $D_{50}$ is equal to the total weight of all particles with diameters less than or equal to $D_{50}$, in millimeters; and

GRA - local gradient of channel, in feet per mile. 


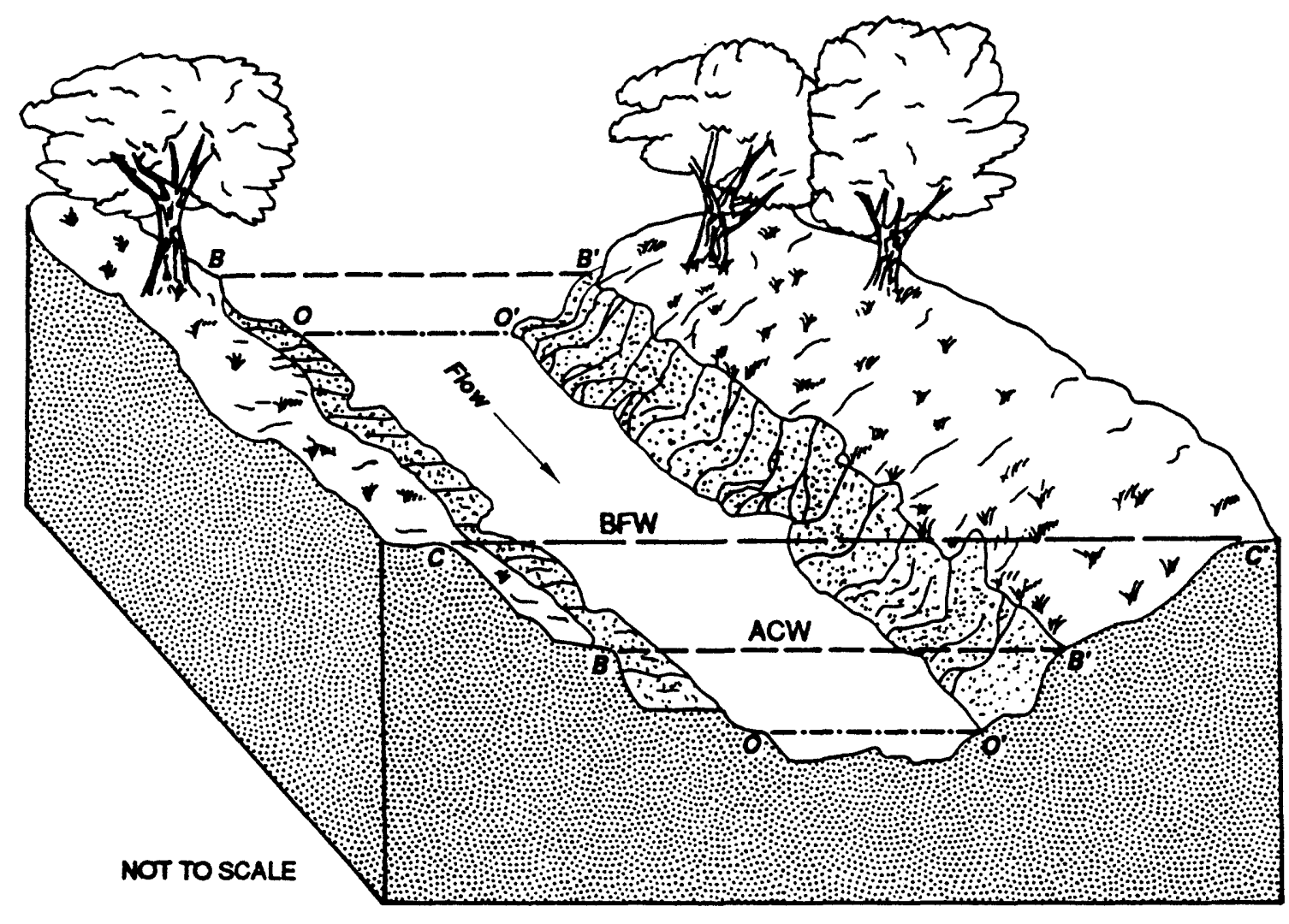

\section{EXPLANATION}

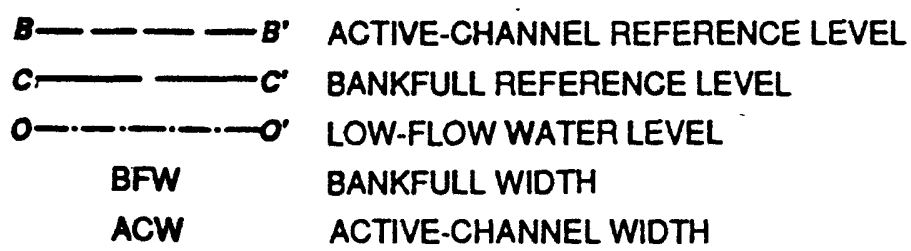

Figure 6. Block diagram of a typical stream channel.

The active-channel and bankfull reference levels for a typical stream channel are illustrated in figure 6. Photographs of active-channel and bankfull reference levels at six gaging stations in Iowa are shown in figure 7.

A standard particle-size analysis (dry sieve, visual accumulation tube, and wet sieve) was performed for each of the composite sediment samples collected from the channel bed and the left and right channel banks (Guy, 1969). The local gradient (GRA) was measured from 1:24,000-scale topographic maps and was calculated as the slope of the channel between the nearest contour lines crossing the channel upstream and downstream of the gaging station.

Of the 157 gaging stations selected for study using the channel-geometry flood-estimation method, 46 were on stream channels that were or were suspected of being channelized. Bankfull width $(B F W)$ and bankfull depth $(B F D)$ measurements could not be made for these sites because channelization affects the long-term, stabilizing conditions of stream channels. Active-channel width $(A C W)$ and active-channel depth $(A C D)$ measurements were made at these 46 sites because channel conditions indicated that the active-channel portions of these 


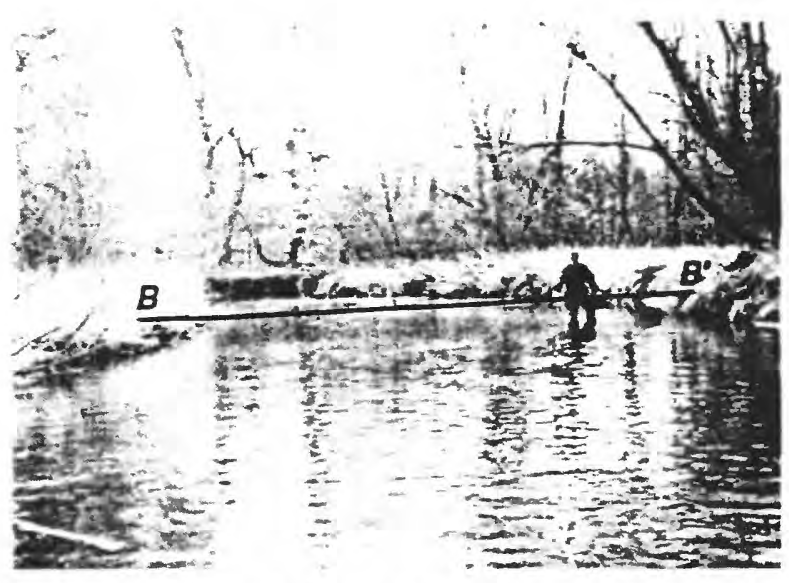

A. Willow Creek near Mason City

(station number 05460100; map number 69 , fig. 2)

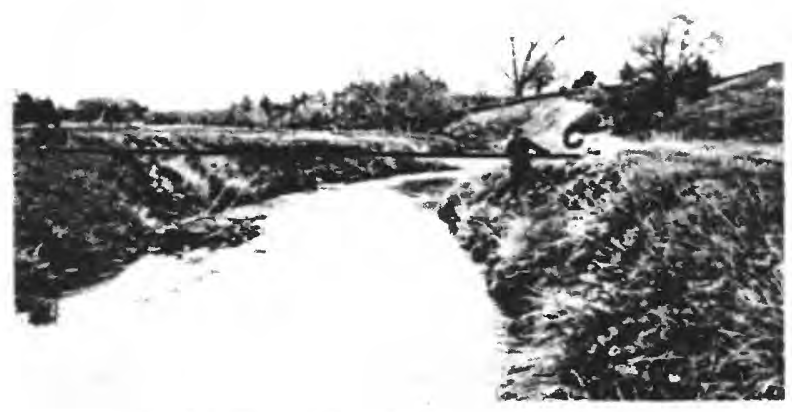

C. Keigley Branch near Story City (station number 05469990; map number 85 , fig. 2)

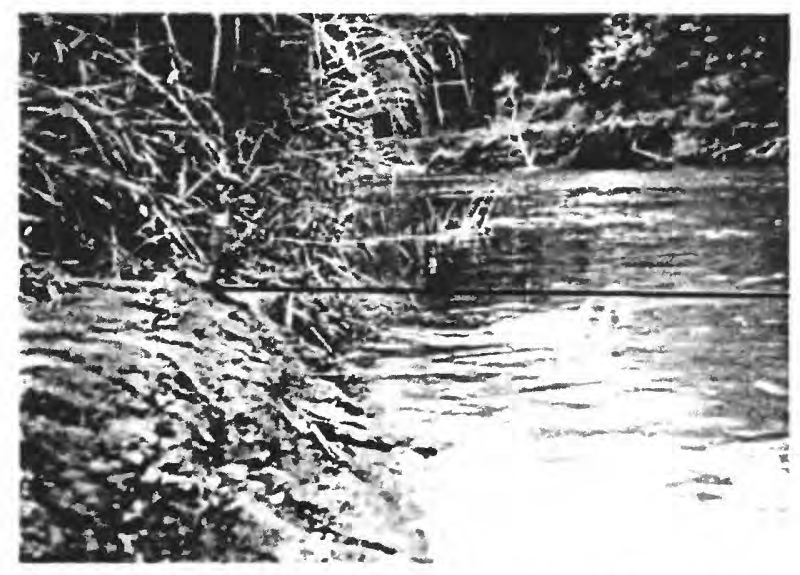

E. Middle Raccoon River near Bayard (station number 05483450; map number 115 , fig. 2)

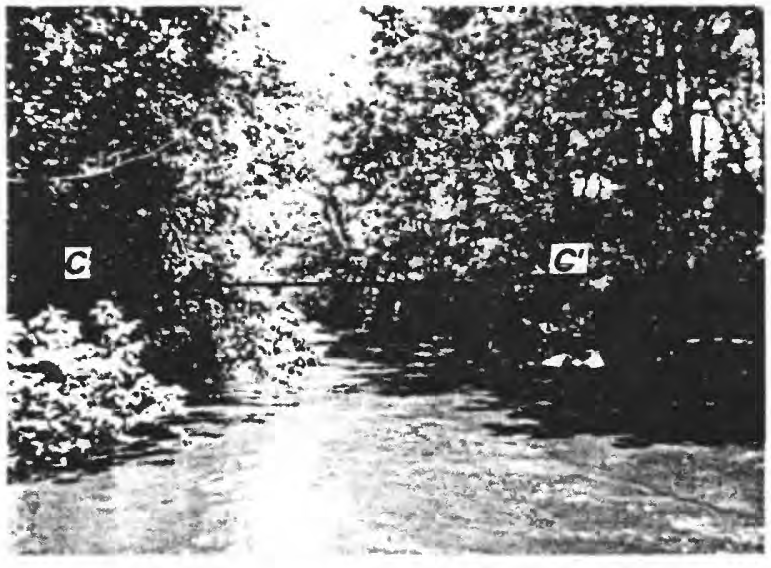

B. Black Hawk Creek at Grundy Center (station number 05463090; map number 73 , fig. 2)

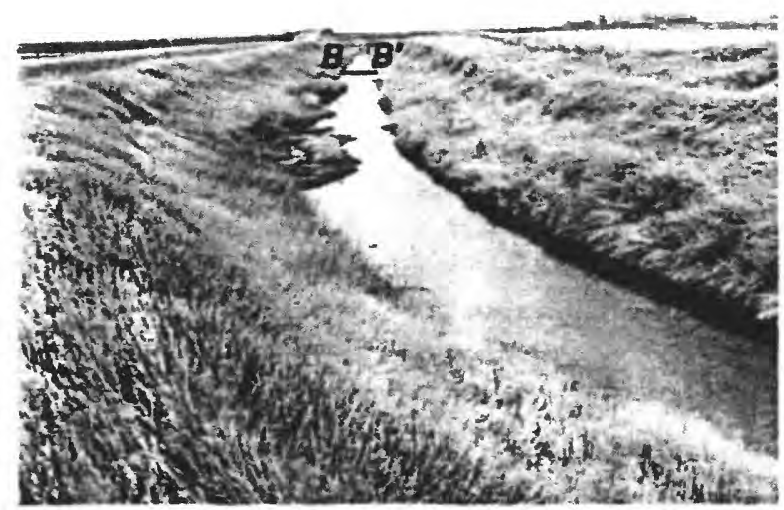
D. Big Cedar Creek near Varina (station number 05482170; map number 108 , fig. 2)

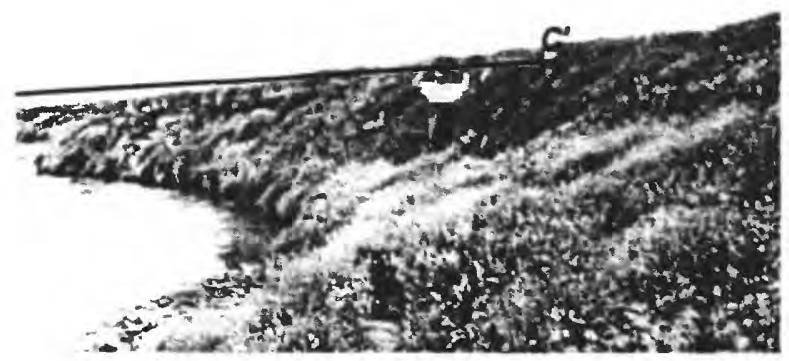

F. West Branch Floyd River near Struble (station number 06600300 ; map number 144, fig. 2)

Figure 7. Active-channel (B-B') and bankful (C-C') reference levels at six streamflow-gaging stations in lowa. 
channels had stabilized. Commonly, the active-channel portion of the channel will adjust back to natural or stable conditions within approximately 5 to 10 years after channelization occurs (Waite Osterkamp, U.S. Geological Survey, oral commun., October 1992). Two data sets thus were compiled for the channel-geometry multiple-regression analyses: a 157-station data set that did not include bankfull measurements and a 111-station data set (a subset of the 157-station data set) that included both the active-channel and bankfull measurements.

\section{Channel-Geometry Characteristic Equations}

\section{Analysis of Channel-Geometry Data on a Statewide Basis}

Multiple-regression analyses initially were performed on both data sets. Statewide equations were developed for each data set using the ordinary least-squares (OLS) and weighted least-squares (WLS) multipleregression techniques previously described. The best equations developed in terms of PRESS statistics, coefficients of determination, and standard errors of estimate for each data set are listed in table 3 . The channel-geometry characteristics identified as most significant for the 111-station data set were bankfull width $(B F W)$ and bankfull depth (BFD). The channel-geometry characteristic identified as most significant in the 157-station data set was active-channel width ( $A C W$ ). Table 9 (at end of this report) lists the average values for $B F W$, $B F D$, and $A C W$ for the streamflow-gaging stations analyzed in the 111- and 157-station data sets. Appendix C (at end of this report) outlines the procedure for conducting channelgeometry measurements of these characteristics.

Comparison of the average standard errors of prediction listed in table 3 indicate that the data set that included bankfull measurements provided better estimation accuracy for the design-flood discharges investigated in this study than did the active-channel measurements in the other data set. The size and shape of the channel cross section is assumed to be a function of streamflow discharge and sedimentload transport. The bankfull channel is a longer term geomorphic feature predominately sculptured by larger magnitude discharges, whereas the active channel is a shorter term geomorphic feature that is sculptured by continuous fluctuations in discharge. Because the design-flood discharge equations developed in this study estimate larger magnitude discharges, a multiple regression relation with better estimation accuracy was defined using bankfull characteristics.

In an attempt to further improve the estimation accuracy of the equations, each gaging station was classified into one of six channel types for which separate multipleregression analyses were performed. Gaging stations were classified according to channeltype classifications described by Osterkamp and Hedman (1982, p. 8). This classification is based on the results of the sediment-sample analyses of percent silt-clay content $\left(S C_{\mathrm{bd}}\right)$ and diameter size $\left(D_{50}\right)$ of the channel-bed particles, and the percent silt-clay content of the left $\left(S C_{\mathrm{lbk}}\right)$ and right bank $\left(S C_{\mathrm{rbk}}\right)$ material. The channelgeometry flood-estimation equations developed using this procedure were inconclusive because the estimation accuracy of some channel-type equations improved while the estimation accuracy of other equations decreased. An analysis of covariance procedure described by W.O. Thomas, Jr., (U.S. Geological Survey, written commun., 1982), wherein each channeltype classification was identified as a qualitative variable, was used to test whether there was a statistical difference due to channel-type classifications. Based on the results of this analysis, there was no significant difference between the channel-type equations and the equations developed without channel-type classification. Because of the results of these two channel-type analyses, statewide channel-geometry equations classified according to sediment-sample analyses were determined to not significantly improve the estimates of design-flood discharges for streams in Iowa.

\section{Analysis of Channel-Geometry Data by Selected Regions}

Examination of residuals for both sets of statewide channel-geometry equations listed in table 3 indicated evidence of geographic bias with respect to the Des Moines Lobe landform 
Table 3. Statewide channel-geometry characteristic equations for estimating design-flood discharges in Iowa

$[Q$, peak discharge, in cubic feet per second, for a given recurrence interval, in years; $B F W$, bankfull width, in feet; $B F D$, bankfull depth, in feet; $A C W$, active-channel width, in feet]

\begin{tabular}{|c|c|c|c|}
\hline & $\begin{array}{l}\text { Standard } \\
\text { error of estimate }\end{array}$ & $\begin{array}{c}\text { Average } \\
\text { standard error } \\
\text { of prediction }\end{array}$ & $\begin{array}{l}\text { Average } \\
\text { equivalent } \\
\text { years of }\end{array}$ \\
\hline Estimation equation & $\log _{10}$ Percent & (percent) & record \\
\hline
\end{tabular}

Bankfull equations

Number of streamflow-gaging stations $=111$

$Q_{2}=4.56 B F W^{0.982} B F D^{1.02}$
$Q_{5}=14.7 B F W^{0.915} B F D^{0.899}$

Active-channel equations

Number of streamflow-gaging stations $=157$

\begin{tabular}{|c|c|c|c|c|}
\hline $\mathrm{Q}_{2}=38.5 A C W^{1.06}$ & 0.267 & 67.8 & 68.3 & 1.6 \\
\hline$Q_{5}=98.2 A C W^{0.980}$ & .247 & 61.9 & 62.3 & 2.1 \\
\hline $\mathrm{Q}_{10}=157 A C W^{0.937}$ & .246 & 61.5 & 61.9 & 2.8 \\
\hline $\mathrm{Q}_{25}=256 A C W^{0.891}$ & .251 & 63.0 & 63.6 & 3.6 \\
\hline $\mathrm{Q}_{50}=349 A C W^{0.861}$ & .258 & 65.1 & 65.8 & 4.8 \\
\hline $\mathrm{Q}_{100}=458 A C W^{0.833}$ & .267 & 67.7 & 68.4 & 6.3 \\
\hline
\end{tabular}

Note: Bankfull equations may provide improved accuracies over active-channel equations for channels unaffected by channelization. For channels affected by channelization, the active-channel equations only are applicable when the active channels have stabilized (approximately 5 to 10 years after channelization). See Appendix $\mathbf{C}$ for a discussion of stabilized channels. 
region (fig. 2). Consequently, both data sets were split into regional data sets, and additional multiple-regression analyses were performed for two regions in Iowa.

The State was divided into two hydrologic regions using information on areal trends of the residuals for the statewide regression equations, the Des Moines Lobe landform region, and topography as guides. The delineation of channel-geometry Regions I and II is shown in figure 2. The topography of the Des Moines Lobe landform region (Region II) is characteristic of a young, postglacial landscape that is unique with respect to the topography of the rest of the State (Region I) (Prior, 1991, p. $30-47)$. The region generally comprises low-relief terrain, accentuated by natural lakes, potholes, and marshes, where surface-water drainage typically is poorly defined and sluggish. The shaded area between hydrologic Regions I and II (fig. 2) represents a transitional zone where the channel morphology of one region gradually merges into the other. This regionalization process served to compensate for the geographic bias observed in the statewide residual plots, which was not accounted for otherwise in the 111- and 157-station channelgeometry regression equations listed in table 3.

Using the OLS and WLS multipleregression techniques previously described, two sets of flood-estimation equations were developed for each channel-geometry region. Of the 111-station data set, 78 stations were in Region I and 33 stations were in Region II. Of the 157-station data set, 120 stations were in Region I and 37 stations were in Region II. Gaging stations located within the regional transition zone (fig. 2) were compiled into either Region I or Region II data sets on the basis of residuals from the statewide regression equations and on the regional locations of their stream channels. The best equations developed in terms of PRESS statistics, coefficients of determination, and standard errors of estimate for the Region I data sets are listed in table 4 and the best equations developed for the Region II data sets are listed in table 5 .

The channel-geometry characteristic that was identified as most significant in the Region I 78-station bankfull equations was bankfull width $(B F W)$. The characteristic identified as most significant in the Region I 120-station active-channel equations was active-channel width $(A C W)$. The channel-geometry characteristics that were identified as most significant in the Region II 33-station bankfull equations were bankfull width ( $B F W)$ and bankfull depth $(B F D)$, and the most significant characteristic in the Region II 37-station active-channel equations was active-channel width $(A C W)$. Appendix $\mathrm{C}$ (at end of this report) outlines the procedure for conducting channel-geometry measurements of these characteristics.

\section{Comparison of Regional and Statewide Channel-Geometry Equations}

Comparison of the Region I and II equations with the statewide equations shows an improvement in the average standard errors of prediction for all of the regional equations except the 25-, 50- and 100-year recurrence intervals of the Region II active-channel equations. The regional equations listed in tables 4 and 5 may provide improved accuracies for estimating design-flood discharges based on channel-geometry measurements. The statewide equations listed in table 3 also can be used to estimate design-flood discharges, although their accuracies may be less than for the regional equations. Comparison of the bankfull equations with the active-channel equations listed in tables 3-5 shows an improvement in the average standard errors of prediction for all of the bankfull equations. The bankfull equations may provide improved estimation accuracies in comparison to activechannel equations for estimating design-flood discharges for channels unaffected by channelization.

Bankfull depth (BFD) was identified as a significant channel-geometry characteristic in the statewide bankfull equations (table 3 ). It is also a significant channel-geometry characteristic in the estimation of design-flood discharges for stream sites located within the Des Moines Lobe landform region (fig. 2, Region II). While bankfull depth was not identified as significant in estimating flood discharges in Region I, it appears to be a significant morphologic feature distinguishing stream channels in Regions I and II. 
Table 4. Region I channel-geometry characteristic equations for estimating design-flood discharges in Iowa outside of the Des Moines Lobe landform region ${ }^{1}$

$[Q$, peak discharge, in cubic feet per second, for a given recurrence interval, in years; $B F W$, bankfull width, in feet; $A C W$, active-channel width, in feet]

\begin{tabular}{|c|c|c|c|}
\hline & $\begin{array}{c}\text { Standard } \\
\text { error of estimate }\end{array}$ & $\begin{array}{c}\text { Average } \\
\text { standard error } \\
\text { of prediction }\end{array}$ & $\begin{array}{l}\text { Average } \\
\text { equivalent } \\
\text { years of }\end{array}$ \\
\hline Estimation equation & $\log _{10} \quad$ Percent & (percent) & record \\
\hline
\end{tabular}

Bankfull equations

Number of streamflow-gaging stations $=78$

\begin{tabular}{llrlrl}
$Q_{2}$ & $=4.55 B F W^{1.45}$ & 0.160 & 38.1 & 38.9 & 4.8 \\
$Q_{5}$ & $=15.6 B F W^{1.32}$ & .140 & 33.1 & 33.8 & 7.4 \\
$Q_{10}$ & $=29.2 B F W^{1.25}$ & .146 & 34.5 & 35.4 & 8.8 \\
$Q_{25}=55.7 B F W^{1.18}$ & .162 & 38.5 & 39.8 & 9.8 \\
$Q_{50}=84.2 B F W^{1.13}$ & .176 & 42.3 & 43.9 & 12.6 \\
$Q_{100}=122 B F W^{1.09}$ & .192 & 46.4 & 48.3 & 16.1 \\
\hline
\end{tabular}

Active-channel equations

Number of streamflow-gaging stations $=120$

\begin{tabular}{|c|c|c|c|c|}
\hline$Q_{2}=45.6 A C W^{1.07}$ & 0.213 & 52.1 & 53.0 & 2.4 \\
\hline$Q_{5}=118 A C W^{0.982}$ & .180 & 43.2 & 44.2 & 4.0 \\
\hline$Q_{10}=190 A C W^{0.937}$ & .175 & 41.9 & 43.0 & 5.4 \\
\hline$Q_{25}=312 A C W^{0.889}$ & .179 & 43.1 & 44.5 & 7.0 \\
\hline$Q_{50}=427 A C W^{0.858}$ & .188 & 45.3 & 46.9 & 8.9 \\
\hline$Q_{100}=566 A C W^{0.828}$ & .198 & 48.2 & 50.0 & 11.0 \\
\hline
\end{tabular}

${ }^{1}$ The Des Moines Lobe landform region is delineated as Region II in figure 2.

Note: Bankfull equations may provide improved accuracies over active-channel equations for channels unaffected by channelization. For channels affected by channelization, the active-channel equations only are applicable when the active channels have stabilized (approximately 5 to 10 years after channelization). See Appendix $\mathrm{C}$ for a discussion of stabilized channels. 
Table 5. Region II channel-geometry characteristic equations for estimating design-flood discharges in Iowa within the Des Moines Lobe landform region ${ }^{1}$

$[Q$, peak discharge, in cubic feet per second, for a given recurrence interval, in years; $B F W$, bankfull width, in feet; $B F D$, bankfull depth, in feet; $A C W$, active-channel width, in feet]

\begin{tabular}{|c|c|c|c|c|}
\hline \multirow[b]{2}{*}{ Estimation equation } & \multicolumn{2}{|c|}{$\begin{array}{c}\text { Standard } \\
\text { error of estimate } \\
\end{array}$} & \multirow{2}{*}{$\begin{array}{c}\text { Average } \\
\text { standard error } \\
\text { of prediction } \\
\text { (percent) }\end{array}$} & \multirow{2}{*}{$\begin{array}{l}\text { Average } \\
\text { equivalent } \\
\text { years of } \\
\text { record } \\
\end{array}$} \\
\hline & $\log _{10}$ & Percent & & \\
\hline \multicolumn{5}{|c|}{ Bankfull equations } \\
\hline \multicolumn{5}{|c|}{ Number of streamflow-gaging stations $=33$} \\
\hline$Q_{2}=2.77 \mathrm{BFW}^{0.844} B F D^{1.48}$ & 0.123 & 28.8 & 30.3 & 6.5 \\
\hline$Q_{5}=7.42 \mathrm{BFW}^{0.783} B F D^{1.43}$ & .131 & 30.8 & 33.6 & 6.1 \\
\hline$Q_{10}=12.1 B F W^{0.748} B F D^{1.41}$ & .143 & 33.9 & 37.7 & 6.3 \\
\hline$Q_{25}=19.7 \mathrm{BFW}^{0.715} B F D^{1.38}$ & .162 & 38.6 & 43.4 & 6.6 \\
\hline$Q_{50}=26.7 \mathrm{BFW}^{0.694} B F D^{1.37}$ & .176 & 42.3 & 47.8 & 7.9 \\
\hline$Q_{100}=34.9 \mathrm{BFW}^{0.675} B F D^{1.36}$ & .190 & 45.9 & 52.1 & 9.3 \\
\hline
\end{tabular}

Active-channel equations

Number of streamflow-gaging stations $=37$

\begin{tabular}{|c|c|c|c|c|}
\hline$Q_{2}=7.80 A C W^{1.30}$ & 0.236 & 58.5 & 59.7 & 1.9 \\
\hline$Q_{5}=19.1 A C W^{1.23}$ & .235 & 58.4 & 60.1 & 2.1 \\
\hline$Q_{10}=29.6 A C W^{1.19}$ & .240 & 59.7 & 61.8 & 2.6 \\
\hline$Q_{25}=45.6 A C W^{1.16}$ & .248 & 62.0 & 64.8 & 3.3 \\
\hline$Q_{50}=59.5 A C W^{1.14}$ & .255 & 64.2 & 67.4 & 4.4 \\
\hline$Q_{100}=75.0 A C W^{1.12}$ & .262 & 66.4 & 70.0 & 5.7 \\
\hline
\end{tabular}

${ }^{1}$ The Des Moines Lobe landform region is delineated as Region II in figure 2.

Note: Bankfull equations may provide improved accuracies over active-channel equations for channels unaffected by channelization. For channels affected by channelization, the active-channel equations only are applicable when the active channels have stabilized (approximately 5 to 10 years after channelization). See Appendix $\mathrm{C}$ for a discussion of stabilized channels. 
The differences in peak-discharge estimation between regional and statewide active-channel width $(A C W)$ equations are shown in figures $8 B$ and $9 B$ for the 2- and 100-year recurrence intervals, respectively. Figures $8 B$ and $9 B$ illustrate the higher estimated peak discharges obtained from the Region I equations relative to those obtained from the Region II equations for a specified active-channel width. The slopes of the Region I regression lines are parallel to those of the statewide regression lines at a higher estimated discharge. The Region II regression lines have steeper slopes relative to the Region I and statewide regression lines but at a lower estimated discharge. Figures $8 A$ and $9 A$ illustrate the relation of the Region I, bankfull regression equations for 2- and 100-year recurrence-interval discharges, respectively. Tests performed using STATIT procedure REGGRP (Statware, Inc., 1990, p. 6-32 - 6-36) indicated that there were statistically significant differences in the slopes and intercepts of the Region I and Region II regression lines for both the bankfull and active-channel equations.

The paired-t test was used to test whether design-flood discharge estimates obtained by both the bankfull and active-channel regression equations for the same gaging station were significantly different at the 95-percent level of significance. The paired-t test was applied using STATIT procedure HYPOTH (Statware, Inc., 1990 , p. 3-21 - 3-23). For table 3, discharge estimates for 111 stations were not significantly different for all design-flood recurrence intervals. For table 4, discharge estimates for 78 stations were significantly different for the 2-year recurrence interval, but estimates were not significantly different for the 5-year to 100-year recurrence intervals. For table 5, discharge estimates for 33 stations were not significantly different for all design-flood recurrence intervals.

The application of the channel-geometry regression equations listed in tables 4 and 5 for a stream site are determined by two factors, and the application of the channel-geometry equations listed in table 3 are determined only by the second factor. First, the stream site is located in figure 2 to determine whether Region I or Region II equations apply. The user may be faced with a dilemma if design-flood discharges are to be estimated for a stream site located within the shaded transitional zone or for a stream that crosses regional boundaries. The discharges could be estimated using both the Region I and II equations and hydrologic judgment used to select the most reasonable design-flood estimate, or a weighted average based on the proportion of drainage area within each region could be applied. The most reasonable alternative to resolving this dilemma may be to use the statewide equations listed in table 3 because they preclude regional subjectivity and the majority of statewide design-flood estimates calculate between Region I and Region II estimates.

Second, the stream site is inspected to determine whether the stream was channelized. If evidence of channelization is not found, then the bankfull equations are applicable (the first set of equations listed in tables 3,4 , and 5); if evidence of channelization is found, then the active-channel equations may be applicable for stabilized channels (the second set of equations listed in tables 3, 4, and 5). Appendix C (at end of this report) outlines a procedure for identifying channelized streams and describes the stabilization conditions for which channelgeometry measurements of channelized streams are applicable.

\section{Examples of Equation Use--Examples 2-4}

Example 2.--Use a regional, channelgeometry equation to estimate the 100-year peak discharge for the discontinued Black Hawk Creek at Grundy Center crest-stage gaging station (station number 05463090; map number 73, fig. 2), located in Grundy County, at a bridge crossing on State Highway 14, at the north edge of Grundy Center, in the NW1/4 sec. 7, T. 87 N., R. $16 \mathrm{~W}$.

Step 1. The appropriate regional equation is determined on the basis of which hydrologic region the stream site is located in and whether the stream has been channelized. This gaging station is located in Region I, and an inspection of the USGS 1:100,000-scale Grundy County map and a visit to the site show no evidence of channelization. Therefore the 100-year bankfull equation for Region I, listed in the first set of 


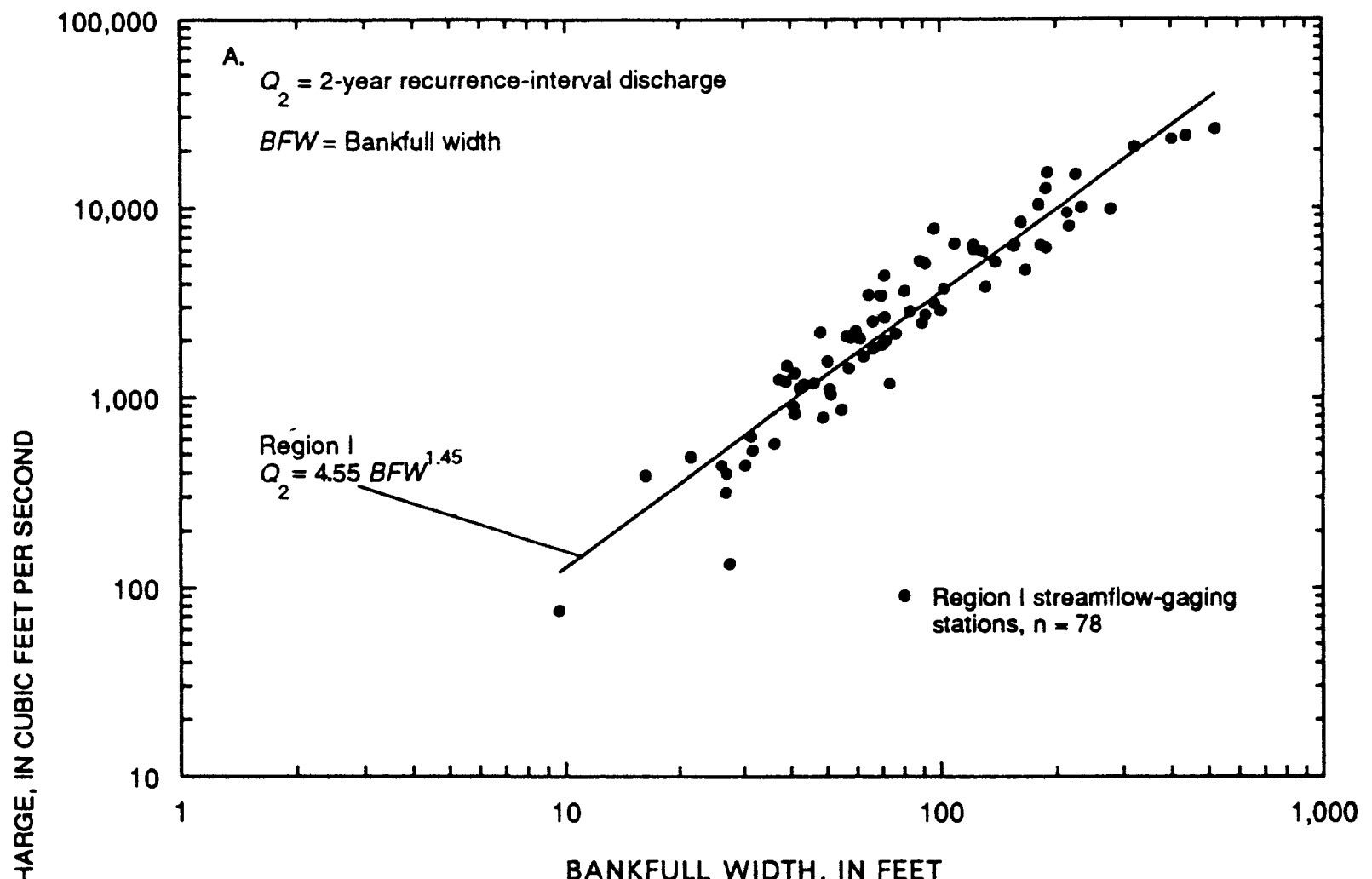

BANKFULL WIDTH, IN FEET

B.

$Q_{2}=2$-year recurrence-interval discharge $A C W=$ Active - channel width

1000

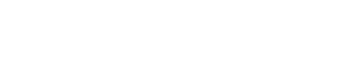




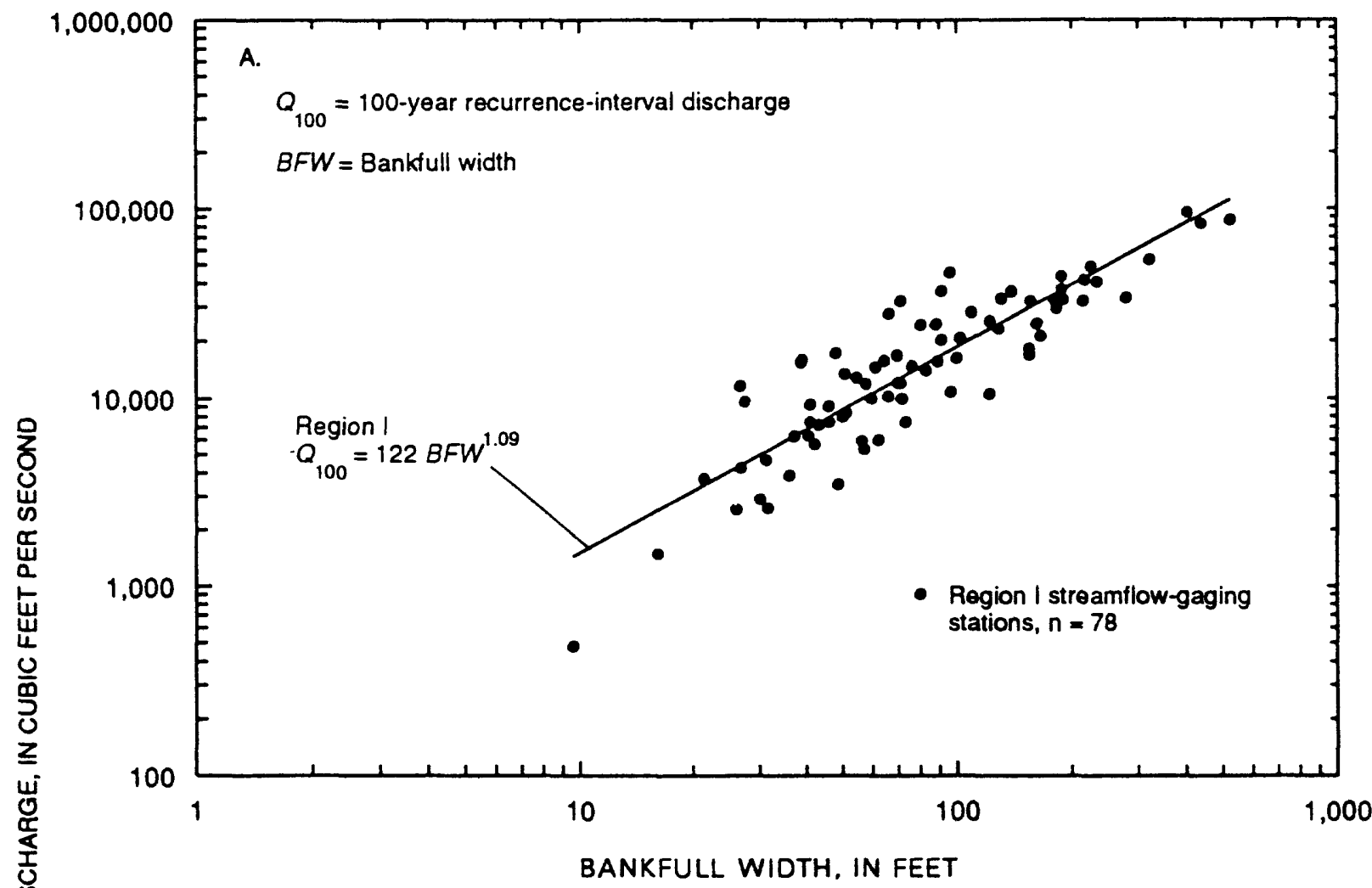

$1,000,000$

B.

$Q_{100}=100$-year recurrence-interval discharge

$A C W=$ Active channel width

10,000

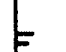

$$
A C W=\text { Active channel widh }
$$


equations in table 4 , is determined to be the most applicable. The only channel-geometry characteristic used for the Region I bankfull equation is the bankfull width ( $B F W)$. Appendix $\mathrm{C}$ describes the procedure for conducting this channel-geometry measurement.

Step 2. Three bankfull widths measuring 52, 50 , and $52 \mathrm{ft}$, measured along a straight channel reach about $0.75-1.0 \mathrm{mi}$ downstream of the gaging station, were used to calculate an average bankfull width $(B F W)$ of $51 \mathrm{ft}$. Figure $7 B$ shows the bankfull reference level at one of these channel measurement sections.

Step 3. The 100-year flood estimate for the Region I bankfull equation (table 4 ) is calculated as

$$
\begin{aligned}
Q_{100} & =122(B F W)^{1.09}, \\
& =122(51)^{1.09}, \\
& =8,860 \mathrm{ft}^{3} / \mathrm{s} .
\end{aligned}
$$

Example 3.--Use a regional channelgeometry equation to estimate the 50-year peak discharge for the Big Cedar Creek near Varina continuous-record gaging station (station number 05482170; map number 108, fig. 2), located in Pocahontas County, at a bridge crossing on County Highway N33, $5.5 \mathrm{mi}$ northeast of Varina, in the NE1/4 sec. 24, T. 91 N., R. 34 W.

Step 1. This gaging station is located in Region II, and an inspection of the USGS 1:100,000-scale Pocahontas County map and a visit to the site show evidence of channelization. Therefore, the 50-year active-channel equation for Region II, listed in the second set of equations in table 5 , is determined to be the most applicable. Features that are characteristic of channelized streams are illustrated in figure $7 D$, which shows the straightened and leveed channel reach downstream of the gage. The only channel-geometry characteristic used for the Region II active-channel equation is the active-channel width (ACW). Appendix $\mathrm{C}$ describes the procedure for conducting this channel-geometry measurement.

Step 2. Three active-channel widths measuring 25.6, 25.3, and $24.2 \mathrm{ft}$, measured along a straight channel reach about $0.25-0.5 \mathrm{mi}$ downstream of the gaging station, were used to calculate an average active-channel width
$(A C W)$ of $25.0 \mathrm{ft}$. Figure $7 D$ shows the approximate active-channel reference level for the channel reach measured to calculate an average active-channel width.

Step 3. The 50-year flood estimate for the Region II active-channel equation (table 5) is calculated as

$$
\begin{aligned}
Q_{50} & =59.5(A C W)^{1.14}, \\
& =59.5(25.0)^{1.14}, \\
& =2,330 \mathrm{ft}^{3} / \mathrm{s} .
\end{aligned}
$$

Example 4.--Use a statewide channelgeometry equation in table 3 to estimate the 100-year peak discharge for the gaging station used in example 2.

Step 1. Because a statewide equation is to be used and no evidence of channelization is evident, as determined in example 2 , the 100-year bankfull equation listed in the first set of equations in table 3 is applicable. Bankfull width $(B F W)$ and bankfull depth $(B F D)$ are the channel-geometry characteristics used for this equation. Appendix $\mathrm{C}$ describes the procedure for conducting these channel-geometry measurements.

Step 2. The average bankfull width ( $B F W$ ) calculation of $51 \mathrm{ft}$ for this stream channel is outlined in example 2 .

Step 3. The average bankfull depth (BFD) for this stream channel was calculated to be 6.0 $\mathrm{ft}$. The bankfull depth measurements used to determine this average are listed in the "Bankfull-Depth (BFD) Measurements" section of Appendix C, and they are illustrated in figure 10.

Step 4. The 100-year flood estimate for the statewide bankfull equation (table 3 ) is calculated as

$$
\begin{aligned}
Q_{100} & =104(B F W)^{0.766}(B F D)^{0.747} \\
& =104(51)^{0.766}(6.0)^{0.747}, \\
& =8,060 \mathrm{ft}^{3} / \mathrm{s} .
\end{aligned}
$$

Examples 2 and 4 illustrate the use of bankfull measurements in computing 100-year flood estimates for this gaging station using regional and statewide multiple-regression equations. The regional estimate was determined to be $8,860 \mathrm{ft}^{3} / \mathrm{s}$, and the statewide estimate was determined to be $8,060 \mathrm{ft}^{3} / \mathrm{s}$. 


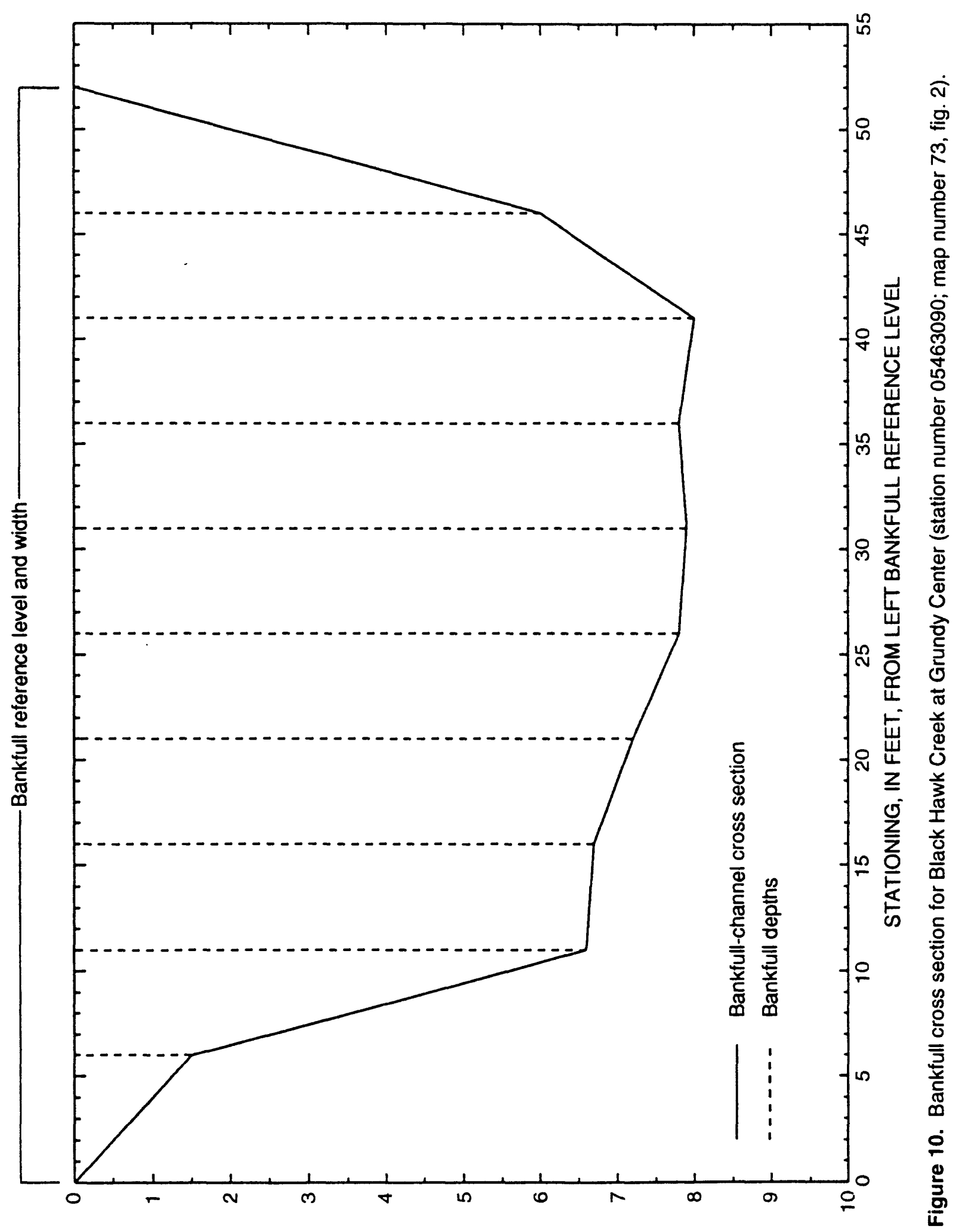

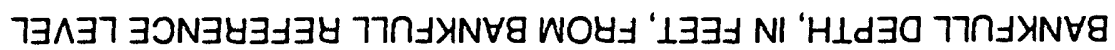




\section{APPLICATION AND RELIABILITY OF FLOOD-ESTIMATION METHODS}

The regression equations developed in this study for both the drainage-basin and channel-geometry flood-estimation methods apply only to streams in Iowa where peak streamflow is not affected substantially by stream regulation, diversion, or other human activities. The drainage-basin method does not apply to basins in urban areas unless the effects of urbanization on surface-water runoff are negligible. The channel-geometry method does not apply to channels that have been altered substantially from their stabilized conditions by human activities, as outlined in Appendix C.

\section{Limitations and Accuracy of Equations}

The applicability and accuracy of the drainage-basin and channel-geometry floodestimation methods depend on whether the drainage-basin or channel-geometry characteristics measured for a stream site are within the range of the characteristic values used to develop the regression equations. The acceptable range for each of the drainage-basin characteristics used to develop the statewide equations (table 2) are tabulated as maximum and minimum values in table 6 . Likewise, the acceptable range for each of the channelgeometry characteristics used to develop the statewide and regional equations (tables 3-5) also are tabulated as maximum and minimum values in table 6 . The applicability of the drainage-basin and channel-geometry equations is unknown when the characteristic values associated with a stream site are outside of the acceptable ranges.

The standard errors of estimate and average standard errors of prediction listed in tables 2-5 are indexes of the expected accuracy of the regression-equation estimates in that they provide measures of the difference between the regression estimate and the Pearson Type-III estimate for a design-flood recurrence interval. If all assumptions for applying regression techniques are met, the difference between the regression estimate and the Pearson Type-III estimate for a design-flood recurrence interval will be within one standard error approximately two-thirds of the time.

The standard error of estimate is a measure of the distribution of the observed annual-peak discharges about the regression surface (Jacques and Lorenz, 1988, p. 17). The average standard error of prediction includes the error of the regression equation as well as the scatter about the equation (Hardison, 1971, p. C228). Although the standard error of estimate of the regression gives an approximation of the standard error of peak discharges, the average standard error of prediction provides more precision in the expected accuracy with which estimates of peak discharges can be made. The average standard error of prediction is estimated by taking the square root of the PRESS statistic mean. Because the standard errors of estimate and average standard errors of prediction are expressed as logarithms (base $10)$, they are converted to percentages by methods described by Hardison (1971, p. C230).

The average standard errors of prediction for the regression models ranged as follows: statewide drainage-basin equations, 38.6 to 50.2 percent (table 2); statewide channel-geometry bankfull equations, 41.0 to 60.4 percent (table 3 ; statewide channel-geometry active-channel equations, 61.9 to 68.4 percent (table 3 ); Region I channel-geometry bankfull equations, 33.8 to 48.3 percent (table 4); Region I channelgeometry active-channel equations, 43.0 to 53.0 percent (table 4); Region II channel-geometry bankfull equations, 30.3 to 52.1 percent (table 5); and Region II channel-geometry activechannel equations, 59.7 to 70.0 percent (table 5).

The average equivalent years of record represents an estimate of the number of years of actual streamflow record required at a stream site to achieve an accuracy equivalent to each respective drainage-basin or channel-geometry design-flood discharge estimate. The average equivalent years of record as described by Hardison (1971, p.C231-C233) is a function of the standard deviation and skew of the observed annual-peak discharges at the gaging stations analyzed for each respective regression equation, the accuracy of the regression equation, and the recurrence interval of the design flood. The average equivalent years of record for a design flood with a recurrence 
Table 6. Statistical summary for selected statewide drainage-basin and channel-geometry characteristics, and for selected regional channel-geometry characteristics at streamflow-gaging stations in Iowa

$[C D A$, contributing drainage area, in square miles; $R R$, relative relief, in feet per mile; $D F$, drainage frequency, in number of first-order streams per square mile; TTF, 2-year, 24-hour precipitation intensity, in inches; $B F W$, bankfull width, in feet; $B F D$, bankfull depth, in feet; $A C W$, active-channel width, in feet]

\begin{tabular}{lcccc}
\hline & \multicolumn{4}{c}{ Statewide drainage-basin characteristics } \\
\cline { 2 - 5 } Statistic & $C D A$ & $R R$ & $D F$ & $T T F$ \\
\hline Maximum & 1,060 & 48.7 & 2.95 & 3.26 \\
Minimum & .338 & 1.57 & .043 & 2.82 \\
Mean & 209 & 6.48 & .520 & 3.11 \\
Median & 80.7 & 4.45 & .510 & 3.14 \\
No. of sites & 164 & 164 & 164 & 164 \\
\hline
\end{tabular}

Statewide channel-geometry characteristics

\begin{tabular}{lccc}
\cline { 2 - 4 } Statistic & $B F W$ & $B F D$ & $A C W$ \\
\hline Maximum & 523 & 17.1 & 510 \\
Minimum & 9.6 & 1.7 & 4.2 \\
Mean & 110 & 7.0 & 77.0 \\
Median & 82.7 & 6.7 & 49.8 \\
No. of sites & 111 & 111 & 157 \\
\hline
\end{tabular}

Regional channel-geometry characteristics

\begin{tabular}{lcccccc} 
& \multicolumn{2}{c}{ Region I } & \multicolumn{3}{c}{ Region II } \\
\cline { 2 - 4 } Statistic & $B F W$ & $A C W$ & & $B F W$ & $B F D$ & $A C W$ \\
\hline Maximum & 523 & 510 & 361 & 19.3 & 12.5 & 339 \\
Minimum & 9.6 & 4.2 & 120 & 2.0 & 6.9 \\
Mean & 106 & 73.7 & 106 & 6.6 & 87.4 \\
Median & 71.0 & 46.1 & 120 & 33 & 6.6 & 73.3 \\
No. of sites & 78 & & & 33 & 37 \\
\hline
\end{tabular}

interval of T-years is calculated as (Hardison, 1971, p. C231)

$$
E=r^{2}\left(\frac{\bar{s}}{S E_{\mathrm{p}}}\right)^{2}
$$

where $E \quad$ is the average equivalent years of record, in years;

$r \quad$ is a factor that is a function of the mean weighted skew coefficient of the logarithms (base 10) of the observed annual-peak discharges at the gaging stations used in each respective regression-model data set and the recurrence interval relating the standard error of a T-year peak discharge to the index of variability $(\bar{s})$ and the number of observed annual- 
peak discharges;

$\bar{s} \quad$ is an index of variability equal to the mean standard deviation of the logarithms (base 10) of the observed annual-peak discharges at the gaging stations used in each respective regression-model data set; and

$S E_{\mathrm{p}} \quad$ is the average standard error of prediction, in log units (base 10), estimated using the Press statistic.

Several of the primary drainage-basin characteristics used in the regression equations listed in table 2 are map-scale dependent. Use of maps of scales other than the scales used to develop the equations may produce results that do not conform to the range of estimation accuracies listed for the equations in table 2 . The scale of map to use for manual measurements of each primary drainage-basin characteristic is outlined in Appendix A and Appendix B.

An additional constraint in the application and reliability of the channel-geometry characteristic equations is the requirement to obtain onsite measurements of bankfull or active-channel width, and possibly bankfull depth. Training and experience are required to properly identify the bankfull and activechannel features in order to make these measurements. The variability in making these measurements can be large, even among experienced individuals. As reported by Wahl (1976), based on a test conducted in northern Wyoming, the standard error in estimated discharge due to variation in width measurements alone was about 30 percent $(0.13 \mathrm{log}$ unit). Variation in bankfull-depth measurements probably would increase this standard error in estimated discharge. Wahl (1976) also noted an average bias with respect to the mean channel width of about 14 percent $(0.06 \mathrm{log}$ unit). A truer total standard error, in log units, for a channel-geometry discharge estimate is calculated by Wahl $(1984$, p. 63$)$ as the square root of the sums of the squares of the errors of the regression equation and of the variation and average bias in width measurements. Using the standard error of estimate for the Region I, 100-year flood bankfull equation (table 4) and assuming the standard errors for measuring channel width reported by Wahl (1976), the

true standard error $=\left[(0.192)^{2}+(0.13)^{2}+(0.06)^{2}\right]^{0.5}$, $=0.240$.

This yields an average standard error of 59.6 percent compared to 46.4 percent for the regression equation alone. Wahl $(1984$, p. 64) notes that the variability of the measurements collected in the Wyoming test probably is greater than normally would be encountered in applying channel-geometry measurements in a particular hydrologic area. Sites in the Wyoming test were chosen for their diversity, and they ranged from ephemeral streams in a nearly desert environment to perennial streams in a high mountain environment.

Despite the limitations associated with the channel-geometry method, the equations presented in this report are considered to be useful as a corroborative flood-estimation method with respect to the drainage-basin method. The channel-geometry equations are applicable to all unregulated, stabilized stream channels in the State, whereas the drainagebasin equations are applicable only to stream sites with drainage areas less than $1,060 \mathrm{mi}^{2}$. Although the error of measurement may be larger for channel-geometry characteristics than for drainage-basin characteristics, the variability of channel-geometry measurements made in Iowa are assumed to be not as great as reported by Wahl (1984) for the Wyoming test. An additional advantage in utilizing the channel-geometry method is that design-flood discharge estimates obtained from each flood-estimation method can be used to calculate a weighted average as described in the following section.

\section{Weighting Design-Flood Discharge Estimates}

Design-flood discharges determined using both the drainage-basin and channel-geometry flood-estimation methods are presumed to be independent from each other. Each floodestimation method thus can be used to verify results from the other; when design-flood discharge estimates are independent, the independent estimates can be used to obtain a weighted average (IACWD, 1982, p. 8-1). 


\section{Calculation of Estimates}

Design-flood discharge estimates calculated using both the drainage-basin and channelgeometry flood-estimation methods can be weighted inversely proportional to their variances to obtain a weighted average that has a smaller variance than either of their individual estimates. According to the Interagency Advisory Committee on Water Data (IACWD, 1982), the weighted average is calculated as

$Q_{\mathrm{T}_{(\mathrm{dbcg})}}=\frac{Q_{\mathrm{T}_{(\mathrm{db})}}\left(S E_{(\mathrm{cg})}\right)^{2}+Q_{T(\mathrm{cg})}\left(S E_{(\mathrm{db})}\right)^{2}}{\left(S E_{(\mathrm{db})}\right)^{2}+\left(S E_{(\mathrm{cg})}\right)^{2}}$

where $Q_{\mathrm{T}(\mathrm{dbcg})}$ is the weighted average design-flood discharge, in cubic feet per second, for a selected $\mathrm{T}$-year recurrence interval;

$Q_{\mathrm{T}(\mathrm{db})}$ is the drainage-basin regressionequation design-flood discharge, in cubic feet per second;

$S E_{(\mathrm{cg})}$ is the standard error of estimate, in $\log$ units (base 10), of the channel-geometry regression equation (tables 3-5);

$Q_{\mathrm{T}(\mathrm{cg})}$ is the channel-geometry regression-equation design-flood discharge, in cubic feet per second; and

$S E_{(\mathrm{db})}$ is the standard error of estimate, in $\log$ units (base 10), of the drainage-basin regression equation (table 2 ).

The standard error of estimate $\left(S E_{(\mathrm{dbcg})}\right)$, in $\log$ units (base 10), of the weighted average design-flood discharge estimate $Q_{\mathrm{T}(\mathrm{dbcg})}$ can be calculated as

$$
S E_{(\mathrm{dbcg})}=\left[\frac{\left(S E_{(\mathrm{db})}\right)^{2}\left(S E_{(\mathrm{cg})}\right)^{2}}{\left(S E_{(\mathrm{db})}\right)^{2}+\left(S E_{(\mathrm{cg})}\right)^{2}}\right]^{0.5} .
$$

\section{Example of Weighting--Example 5}

Example 5.--Use the 100-year drainagebasin and channel-geometry regression estimates (table 8 ) to obtain a weighted average, 100-year peak-discharge estimate for the discontinued Black Hawk Creek at Grundy Center crest-stage gaging station (station number 05463090; map number 73, figs. 1 and 2).

The 100-year flood estimate calculated for this gaging station using the drainage-basin equation is $7,740 \mathrm{ft}^{3} / \mathrm{s}$ (listed as method GISDB in table 8), and the standard error of estimate, in log units (base 10), for this equation is 0.198 (table 2). The 100-year flood estimate calculated for this gaging station using the Region I, bankfull channel-geometry equation is 8,860 $\mathrm{ft}^{3} / \mathrm{s}$ (listed as method BFRI in table 8), and the standard error of estimate, in log units, for this equation is 0.192 (listed in the first set of equations in table 4). The weighted average, 100 -year flood estimate is calculated using equation 14 as

$$
\begin{aligned}
Q_{100(\mathrm{dbcg})} & =\frac{Q_{100(\mathrm{db})}\left(S E_{(\mathrm{cg})}\right)^{2}+Q_{100(\mathrm{cg})}\left(S E_{(\mathrm{db})}\right)^{2}}{\left(S E_{(\mathrm{db})}\right)^{2}+\left(S E_{(\mathrm{cg})}\right)^{2}}, \\
& =\frac{7,740(0.192)^{2}+8,860(0.198)^{2}}{(0.198)^{2}+(0.192)^{2}}, \\
& =8,320 \mathrm{ft}^{3} / \mathrm{s} .
\end{aligned}
$$

The standard error of estimate for this weighted average, 100-year peak-discharge estimate is calculated using equation 15 as

$$
\begin{aligned}
S E_{(\mathrm{dbcg})} & =\left[\frac{\left(S E_{(\mathrm{db})}\right)^{2}\left(S E_{(\mathrm{cg})}\right)^{2}}{\left(S E_{(\mathrm{db})}\right)^{2}+\left(S E_{(\mathrm{cg})}\right)^{2}}\right]^{0.5}, \\
& =\left[\frac{(0.198)^{2}(0.192)^{2}}{(0.198)^{2}+(0.192)^{2}}\right]^{0.5}, \\
& =0.138 \log \text { units or } 32.6 \text { percent. }
\end{aligned}
$$

\section{Weighting Design-Flood Discharge Estimates for Gaged Sites}

Weighted design-flood discharges are estimated for a gaged site based on either the Pearson Type-III estimate and regressionequation estimates from both the drainage- 
basin and channel-geometry flood-estimation methods or on the Pearson Type-III estimate and only one of the regression-equation estimates. The design-flood discharge estimate is a weighted average of these values in which the Pearson Type-III estimate for the gaged site is weighted by the effective record length $(E R L)$ at the gaged site, and the regression-equation estimates are weighted by the average equivalent years of record associated with their respective regression equations.

\section{Calculation of Estimates}

The weighted design-flood discharge estimate for a gaged site as outlined by the Interagency Advisory Committee on Water Data (IACWD, 1982, p. 8-1 - 8-2) is calculated as regression-equation design-flood discharge for a gaging station, in cubic feet per second, (listed as either method BFRI, ACRI, ACRII, or BFRII in table 8); and

$E_{\text {(cg) }} \quad$ is the average equivalent years of record for the channel-geometry regression equation used to determine $Q_{\mathrm{T}(\mathrm{gcg})}($ table 4 or 5$)$.

If both the drainage-basin regressionequation estimate $Q_{\mathrm{T}(\mathrm{gdb})}$ and the channelgeometry regression-equation estimate $Q_{\mathrm{T}(\mathrm{gcg})}$ are not available for a gaged site, then equation 16 used to calculate the weighted design-flood discharge estimate $Q_{\mathrm{T}(\mathrm{wg})}$ is simplified to the

$Q_{\mathrm{T}(w g)}=\frac{\left(Q_{\mathrm{T}(\mathrm{g})}\right)(E R L)+\left(Q_{\mathrm{T}(\mathrm{gdb})}\right)\left(E_{(\mathrm{db})}\right)+\left(Q_{\mathrm{T}(\mathrm{gcg})}\right)\left(E_{(\mathrm{cg})}\right)}{E R L+E_{(\mathrm{db})}+E_{(\mathrm{cg})}}$

where $Q_{T(\mathrm{wg})}$ is the weighted design-flood discharge for a gaging station, in cubic feet per second, for a selected $T$-year recurrence interval;

$Q_{\mathrm{T}(\mathrm{g})}$ is the Pearson Type-III design-flood discharge for a gaging station, in cubic feet per second, as determined by the analysis of the observed annual-peak discharge record (listed as method B17B in table 8);

$E R L \quad$ is the effective record length for a gaging station, in years, representing the $Q_{\mathrm{T}(\mathrm{g})}$ analysis (table 8);

$Q_{\mathrm{T}(\mathrm{gdb})}$ is the drainage-basin regressionequation design-flood discharge for a gaging station, in cubic feet per second, (listed as method GISDB in table 8);

$E_{\text {(db) }}$ is the average equivalent years of record for the drainage-basin regression equation used to determine $Q_{\mathrm{T}(\mathrm{gdb})}$ (table 2);

$Q_{\mathrm{T}(\mathrm{gcg})}$ is the channel-geometry weighting of two estimates based on $Q_{\mathrm{T}(\mathrm{g})}$ and $E R L$ and either $Q_{\mathrm{T}(\mathrm{gdb})}$ and $E_{(\mathrm{db})}$ or $Q_{\mathrm{T}(\mathrm{gcg})}$ and $E_{(\mathrm{cg})}$. An example of weighting a gaged site with only one regression-equation estimate is illustrated in "Example 7."

By including both the drainage-basin and channel-geometry regression-equation estimates, or only one of these estimates, with the computed Pearson Type-III estimate for a gaged site, design-flood histories for a relatively long period of time are incorporated into the weighted estimate for the gaged site and tend to decrease the time-sampling error (Choquette, 1988, p. 41). Climatic conditions during a short gaged period of record often are not indicative of the longer term climatic variability associated with a particular gaging station. Such time-sampling error may be particularly large when the observed gaged period of record represents an unusually wet or dry climatic cycle compared to the longer term average climatic conditions. Time-sampling error thus is minimized for a gaging station by weighting the design-flood discharge estimate $Q_{\mathrm{T}(\mathrm{wg})}$.

\section{Examples of Weighting--Examples 6-7}

Example 6.--Calculate a weighted 100-year peak-discharge estimate for the discontinued Black Hawk Creek at Grundy Center crest-stage gaging station (station number 
05463090; map number 73, figs. 1 and 2). An inspection of table 8 lists regression-equation estimates for both the drainage-basin and channel-geometry flood-estimation methods. The 100-year Pearson Type-III estimate is $8,320 \mathrm{ft}^{3} / \mathrm{s}$, and the effective record length is 24 years (table 8 ). The 100-year drainage-basin regression estimate is $7,740 \mathrm{ft}^{3} / \mathrm{s}$ (table 8 ), and the average equivalent years of record for this regression equation is 11.5 (table 2). The 100-year Region I, bankfull channel-geometry regression estimate is $8,860 \mathrm{ft}^{3} / \mathrm{s}$ (table 8 ), and the average equivalent years of record for this regression equation is 16.1 (listed in the first set of equations in table 4). The weighted 100-year flood estimate for this gaging station is calculated using equation 16 as

\section{Estimating Design-Flood Discharges for an Ungaged Site on a Gaged Stream}

Design-flood discharges for an ungaged site on a gaged stream can be estimated if the total drainage area of the ungaged site is between 50 and 150 percent of the total drainage area of the gaged site by an adjustment procedure described by Choquette (1988, p. 42-45) and Koltun and Roberts (1990, p. 6-8). This procedure uses flood-frequency information from the Pearson Type-III and regression-equation estimates at the gaged site to adjust the regression-equation estimate at the ungaged site.

$$
\begin{aligned}
Q_{100(\mathrm{wg})} & =\frac{\left(Q_{100(\mathrm{~g})}\right)(E R L)+\left(Q_{100(\mathrm{gdb})}\right)\left(E_{(\mathrm{db})}\right)+\left(Q_{100(\mathrm{gcb})}\right)\left(E_{(\mathrm{cg})}\right)}{E R L+E_{(\mathrm{db})}+E_{(\mathrm{cg})}}, \\
& =\frac{(8,320)(24)+(7,740)(11.5)+(8,860)(16.1)}{24+11.5+16.1}, \\
& =8,360 \mathrm{ft}^{3} / \mathrm{s} .
\end{aligned}
$$

Example 7--Calculate a weighted 50-year peak-discharge estimate for the discontinued Fox River at Bloomfield gaging station (station number 05494300; map number 133, fig. 1), located in Davis County, at a bridge crossing on a county highway, about $0.5 \mathrm{mi}$ north of Bloomfield, in the SE1/4 sec. 13, T. 69 N., R. 14 $\mathrm{W}$. Table 8 lists a regression-equation estimate for only the drainage-basin flood-estimation method. The 50-year Pearson Type-III estimate is $10,600 \mathrm{ft}^{3} / \mathrm{s}$, and the effective record length is 21 years (table 8). The flood-frequency curve developed from the Pearson Type-III analysis for this gaging station is shown in figure 3 . The 50-year drainage-basin regression estimate is $7,600 \mathrm{ft}^{3} / \mathrm{s}$ (table 8 ), and the average equivalent years of record for this regression equation is 9.5 (table 2). The weighted 50-year flood estimate for this gaging station is calculated using a simplified version of equation 16 as

$$
\begin{aligned}
Q_{50(\mathrm{wg})} & =\frac{\left(Q_{50(\mathrm{~g})}\right)(E R L)+\left(Q_{50(\mathrm{gdb})}\right)\left(E_{(\mathrm{db})}\right)}{E R L+E_{(\mathrm{db})}}, \\
& =\frac{(10,600)(21)+(7,600)(9.5)}{21+9.5}, \\
& =9,670 \mathrm{ft}^{3 / \mathrm{s}} .
\end{aligned}
$$

\section{Calculation of Estimates}

The regression-equation estimate for the ungaged site is determined as one of the following: (1) the weighted average $Q_{T(d b c g)}$ calculated from both the drainage-basin and channel-geometry regression-equation estimates using equation 14 or (2) the regressionequation estimate of $Q_{\mathrm{T}(\mathrm{db})}$ or $Q_{\mathrm{T}(\mathrm{cg})}$ calculated from either one of these flood-estimation methods. The calculation for this adjustment procedure is

$$
Q_{\mathrm{T}(\mathrm{au})}=Q_{\mathrm{T}(\mathrm{ru})}\left[A F-\left(\frac{2 \Delta T D A}{T D A_{\mathrm{g}}}\right)(A F-1)\right],
$$

where $Q_{T(a u)}$ is the adjusted design-flood discharge for the ungaged site, in cubic feet per second, for a selected $T$-year recurrence interval;

$Q_{\mathrm{T}(\mathrm{ru})}$ is the regression design-flood discharge for the ungaged site, in cubic feet per second, determined as one of the following: (1) the weighted average of both the drainage-basin and channel- 
geometry regression-equation estimates $Q_{\mathrm{T}(\mathrm{dbcg})}$ (equation 14); (2) only the drainage-basin regression-equation estimate $Q_{\mathrm{T}(\mathrm{db})}$; or (3) only the channelgeometry regression-equation estimate $Q_{\mathrm{T}(\mathrm{cg})}$;

$A F$ is the adjustment factor for the gaged site and is calculated as

$$
A F=\frac{Q_{T(\mathrm{wg})}}{Q_{T(\mathrm{rg})}},
$$

where $Q_{\mathrm{T}(\mathrm{wg})}$ is the weighted design-flood discharge for the gaged site, in cubic feet per second, as defined by equation 16 ;

$Q_{\mathrm{T}(\mathrm{rg})}$ is the regression design-flood discharge for the gaged site, in cubic feet per second, determined as one of the following: (1) the weighted average of both the drainage-basin and channelgeometry regression-equation estimates $Q_{\mathrm{T}(\mathrm{dbcg})}$, as defined by equation 14; (2) only the drainage-basin regressionequation estimate $Q_{\mathrm{T}(\mathrm{db}) \text {; or (3) }}$ only the channel-geometry regression-equation estimate $Q_{\mathrm{T}(\mathrm{cg})}$;

$\triangle T D A$ is the absolute value of the difference between the total drainage area of the gaged site $\left(T D A_{g}\right)$ and the total drainage area of the ungaged site; and

$T D A_{\mathrm{g}}$ is the total drainage area of the gaged site, in square miles, listed as the published drainage area in table 9 .

This procedure (1) adjusts the regression-equation estimate for the ungaged site $Q_{\mathrm{T}(\mathrm{ru})}$ by the ratio $A F$ when the total drainage area of the ungaged site equals the total drainage area of the gaged site $T D A_{\mathrm{g}}$ and (2) prorates the adjustment to 1.0 as the difference in total drainage area between the gaged site and the ungaged site approaches either 0.5 or 1.5 of the total drainage area of the gaged site. In other words, when the total drainage area of the ungaged site is 50 percent larger or 50 percent smaller than the total drainage area of the gaged site, no adjustment is applied to the regression-equation estimate for the ungaged site $Q_{\mathrm{T}(\mathrm{ru})}$.

\section{Example of Estimation Method--Example 8}

Example 8.--Determine the 50-year peakdischarge estimate for an ungaged site on Otter Creek, located on the Osceola and Lyon County line, at a bridge crossing on County Highway L26, $4.75 \mathrm{mi}$ southwest of Ashton, in the SW1/4 sec. 31 , T. 98 N., R. 42 W. Because a crest-stage gaging station is located on this stream, Otter Creek near Ashton (station number 06483460; map number 139 , fig. 1 ), the 50-year recurrence interval regression-equation estimate calculated for the ungaged site can be adjusted by the weighted 50-year flood-discharge estimate calculated for the gaged site. Estimating the adjusted 50-year peak discharge for the ungaged site $Q_{50(a u)}$ (equation 17) involves four steps.

Step 1. A regression-equation estimate $Q_{50(\mathrm{ru})}$ (equation 17) is calculated for the ungaged site. Both drainage-basin and channelgeometry flood-estimation methods could be used to calculate a weighted average estimate $Q_{50(\mathrm{dbcg})}$ (equation 14) for the regression estimate $\left(Q_{50(\mathrm{ru})}\right)$ or only one of these flood-estimation methods could be used to calculate the regression-equation estimate $\left(Q_{50(r u)}\right)$. For this example, only the statewide drainage-basin estimate $\left(Q_{50}(\mathrm{db})\right)$ (table 2) will be used for the 50-year recurrence interval regression-equation estimate $\left(Q_{50(\mathrm{ru})}\right)$ at the ungaged site because channel-geometry measurements were not collected for calculating a channel-geometry estimate $\left(Q_{50}(\mathrm{cg})\right.$.

(A). The characteristics used in the drainage-basin equation (table 2) are contributing drainage area $(C D A)$, relative relief $(R R)$, drainage frequency $(D F)$, and 2-year, 24-hour precipitation intensity $(T T F)$. The primary drainage-basin characteristics used in this equation are total drainage area (TDA), noncontributing drainage area $(N C D A)$, basin relief $(B R)$, basin perimeter $(B P)$, number of first-order streams (FOS), and 2-year, 24-hour 
precipitation intensity $(T T F)$. These primary drainage-basin characteristic measurements and the scale of maps to use for each manual measurement are described in Appendix A and Appendix B.

(B). The topographic maps used to delineate the drainage-divide boundary for this ungaged site are the DMA 1:250,000-scale Fairmont topographic map and the USGS 1:100,000-scale Osceola County map. Contributing drainage area $(C D A)$ is calculated from the primary drainage-basin characteristics total drainage area $(T D A)$ and noncontributing drainage area (NCDA). The drainage-divide boundary for this basin is delineated on the 1:250,000-scale map, and the total drainage area (TDA) for the ungaged site is listed in Larimer (1957, p. 313) as $120 \mathrm{mi}^{2}$. The total drainage area published for the gaged site, Otter Creek near Ashton (station number 06483460; map number 139, fig. 1), is $88.0 \mathrm{mi}^{2}$ (table 9). Because the total drainage area of the ungaged site is 136.4 percent of the total drainage area of the gaged site and within the 50- and 150-percent limits for application, the adjustment procedure is determined to be applicable to the ungaged site. Inspection of the 1:100,000-scale map does not show any noncontributing drainage areas within the drainage-divide boundary of this basin. The contributing drainage area $(C D A)$ for the ungaged site is calculated using equation 10 as

$$
\begin{aligned}
C D A & =T D A-N C D A, \\
& =120-0, \\
& =120 \mathrm{mi}^{2} .
\end{aligned}
$$

(C). Relative relief (RR) for the ungaged site is calculated from the primary drainage-basin characteristics basin relief $(B R)$ and basin perimeter $(B P)$. The difference between the highest elevation contour and the lowest interpolated elevation in the basin measured from the 1:250,000-scale topographic map gives a basin relief of $286 \mathrm{ft}$. The drainage-divide boundary delineated on the 1:250,000-scale topographic map is used to measure the basin perimeter, which is $57.8 \mathrm{mi}$. Relative relief $(R R)$ is calculated using equation 11 as

$$
\begin{aligned}
R R & =\frac{B R}{B P}, \\
& =\frac{286}{57.8}, \\
& =4.95 \mathrm{ft} / \mathrm{mi} .
\end{aligned}
$$

(D). Drainage frequency $(D F)$ for the ungaged site is calculated from the primary drainage-basin characteristics number of first-order streams (FOS) and contributing drainage area $(C D A)$. A total of 57 first-order streams are counted within the drainage-divide delineation for the ungaged site on the 1:100,000-scale topographic map. Drainage frequency $(D F)$ is calculated using equation 12 as

$$
\begin{aligned}
D F & =\frac{F O S}{C D A}, \\
& =\frac{57}{120}, \\
& =0.475 \text { first-order streams } / \mathrm{mi}^{2} .
\end{aligned}
$$

(F). The 2-year, 24-hour precipitation intensity $(T T F)$ for the ungaged drainage basin is determined from figure 5 . Because the drainage-divide boundary of this ungaged site overlies two of the 2-year, 24-hour precipitation intensity polygons shown in figure 5 , a weighted average for the basin is computed using equation 19 as outlined in Appendix B. According to figure 5, approximately 60 percent of the total drainage area (TDA) for the ungaged site is located within the polygon labeled as 2.85 in., and approximately 40 percent of the total drainage area is located within the polygon labeled as $2.95 \mathrm{in}$. The weighted average for the 2-year, 24-hour precipitation intensity $(T T F)$ is calculated using equation 19 (Appendix B) as

$$
\begin{aligned}
T T F & =\left(\mathrm{A}_{1}\right)\left(T T F_{1}\right)+\left(\mathrm{A}_{2}\right)\left(T T F_{2}\right), \\
& =(0.60)(2.85)+(0.40)(2.95), \\
& =2.89 \mathrm{in} .
\end{aligned}
$$

(G). The 50-year flood estimate for the ungaged site using the drainage-basin equation (table 2) is calculated as

$$
\begin{aligned}
Q_{50}= & 231(C D A)^{0.694}(R R)^{0.656}(D F)^{0.401}(T T F-2.5)^{0.491}, \\
= & 231(120)^{0.694}(4.95)^{0.656}(0.475)^{0.401} \\
& (2.89-2.5)^{0.491}, \\
= & 8,550 \mathrm{ft}^{3} / \mathrm{s} .
\end{aligned}
$$

Because $Q_{50}=Q_{50(\mathrm{db})}$, and $Q_{50(\mathrm{ru})}$ (equation 17) $=Q_{50(\mathrm{db})}$ in this example, then $Q_{50(\mathrm{ru})}=$ $8,550 \mathrm{ft}^{3} / \mathrm{s}$. 
Step 2. The weighted 50-year peak discharge for the gaged site $Q_{50}(\mathrm{wg})$ (equation 16) is estimated next. Because table 8 lists both the drainage-basin and channel-geometry regression-equation estimates for this gaged site, Otter Creek near Ashton (station number 06483460, map number 139, fig. 1), the weighted estimate will be based on the Pearson Type-III estimate and both of these regression-equation estimates.

The 50-year Pearson Type-III estimate is $11,100 \mathrm{ft}^{3} / \mathrm{s}$, and the effective record length is 39 years (table 8 ). The 50-year drainage-basin regression estimate is $6,710 \mathrm{ft}^{3} / \mathrm{s}$ (listed as method GISDB in table 8 ), and the average equivalent years of record for this regression equation is 9.5 (table 2). The 50-year Region I, active-channel channel-geometry regression estimate is $9,260 \mathrm{ft}^{3} / \mathrm{s}$ (listed as method ACRI in table 8 ), and the average equivalent years of record for this regression equation is 8.9 (listed in the second set of equations in table 4). The weighted 50-year flood estimate for the gaged site is calculated using equation 16 as
$9,260 \mathrm{ft}^{3} / \mathrm{s}$ (listed as method ACRI in table 8), and the standard error of estimate, in log units, for this equation is 0.188 (listed in the second set of equations in table 4). The weighted average, 50-year flood estimate for the gaged site is calculated using equation 14 as

$$
\begin{aligned}
Q_{50(\mathrm{dbcg})} & =\frac{Q_{50(\mathrm{db})}\left(S E_{(\mathrm{cg})}\right)^{2}+Q_{50(\mathrm{cg})}\left(S E_{(\mathrm{db})}\right)^{2}}{\left(S E_{(\mathrm{db})}\right)^{2}+\left(S E_{(\mathrm{cg})}\right)^{2}}, \\
& =\frac{6,710(0.188)^{2}+9,260(0.185)^{2}}{(0.185)^{2}+(0.188)^{2}}, \\
& =7,960 \mathrm{ft}^{3 / \mathrm{s}} .
\end{aligned}
$$

Because $Q_{50(\mathrm{dbcg})}=Q_{50(\mathrm{rg})}$ in this example, then $Q_{50(\mathrm{rg})}=7,960 \mathrm{ft}^{3} / \mathrm{s}$.

Step 4. The final step adjusts the 50-year recurrence interval regression-equation estimate of $8,550 \mathrm{ft}^{3} / \mathrm{s}\left(\mathrm{Q}_{50(\mathrm{ru})}\right)$ calculated for the ungaged site by the 50-year recurrence interval information determined for the gaged site. The adjusted 50-year flood estimate for the ungaged site $Q_{50(a u)}$ is calculated using equations 17 and 18 as

$$
\begin{aligned}
Q_{50(\mathrm{wg})} & =\frac{\left(Q_{50(\mathrm{~g})}\right)(E R L)+\left(Q_{50(\mathrm{gdb})}\right)\left(E_{(\mathrm{db})}\right)+\left(Q_{50(\mathrm{gcg})}\right)\left(E_{(\mathrm{cg})}\right)}{E R L+E_{(\mathrm{db})}+E_{(\mathrm{cg})}}, \\
& =\frac{(11,100)(39)+(6,710)(9.5)+(9,260)(8.9)}{39+9.5+8.9} \quad Q_{50(\mathrm{au})}=Q_{50(\mathrm{ru})}\left[A F-\left(\frac{2 \Delta T D A}{T D A_{\mathrm{g}}}\right)(A F-1)\right] .
\end{aligned}
$$

$\triangle T D A$ is the absolute value of the difference $=10,100 \mathrm{ft}^{3} / \mathrm{s}$.

Step 3. The regression-equation estimate for the gaged site $Q_{50}(\mathrm{rg})$ (equation 18 ) is determined next. Because table 8 lists both the drainage-basin and channel-geometry regression estimates for this gaged site, Otter Creek near Ashton, the weighted average of these regression estimates $Q_{50}(\mathrm{dbcg})$ (equation $14)$ is calculated to determine the regression estimate $Q_{50(\mathrm{rg})}$.

The 50-year flood estimate calculated for this gaging station using the drainage-basin equation is $6,710 \mathrm{ft}^{3} / \mathrm{s}$ (listed as method GISDB in table 8), and the standard error of estimate, in log units (base 10), for this equation is 0.185 (table 2). The 50-year flood estimate calculated for this gaging station using the Region I, active-channel channel-geometry equation is between the total drainage area of the gaged site $\left(88.0 \mathrm{mi}^{2}\right)$ and the total drainage area of the ungaged site $\left(120 \mathrm{mi}^{2}\right)$,

$$
\begin{aligned}
\triangle T D A & =32.0 \mathrm{mi}^{2} ; \\
T D A_{\mathrm{g}} & =88.0 \mathrm{mi}^{2} ; \\
A F & =\frac{Q_{50}(\mathrm{wg})}{Q_{50}(\mathrm{rg})}, \\
A F & =\frac{10,100}{7,960}, \\
\mathrm{AF} & =1.27 ; \\
Q_{50(\mathrm{au})} & =8,550\left[1.27-\left(\frac{(2)(32.0)}{88.0}\right)(1.27-1)\right], \\
& =9,180 \mathrm{ft}^{3} / \mathrm{s} .
\end{aligned}
$$

This adjustment procedure has increased the 50-year recurrence interval regressionequation estimate for the ungaged site $Q_{50(\mathrm{ru})}$ by 
107.4 percent based on the 50-year recurrence interval information determined for the gaged site upstream of this ungaged site.

\section{SUMMARY AND CONCLUSIONS}

Drainage-basin and channel-geometry equations are presented in this report for estimating design-flood discharges having recurrence intervals of $2,5,10,25,50$, and 100 years at stream sites on rural, unregulated streams in Iowa. The equations were developed using ordinary least-squares and weighted least-squares multiple-regression techniques. Statewide equations were developed for the drainage-basin flood-estimation method and statewide and regional equations were developed for the channel-geometry floodestimation method. The drainage-basin equations are applicable to stream sites with drainage areas less than $1,060 \mathrm{mi}^{2}$, and the channel-geometry equations are applicable to stabilized stream channels in Iowa.

Flood-frequency curves were developed for 188 continuous-record and crest-stage gaging stations on unregulated rural streams in Iowa. Pearson Type-III estimates of design-flood discharges are reported for these gaging stations.

Regression analyses of Pearson Type-III design-flood discharges and selected drainagebasin characteristics, quantified using a geographic-information-system (GIS) procedure, were used to develop the statewide drainage-basin flood-estimation equations. The significant characteristics identified for the drainage-basin equations included contributing drainage area; relative relief; drainage frequency; and 2-year, 24-hour precipitation intensity. The regression coefficients for these equations indicated an increase in design-flood discharges with increasing magnitude in the values of each drainage-basin characteristic. The average standard errors of prediction for the drainage-basin equations ranged from 38.6 to 50.2 percent.

Techniques on how to make manual measurements from topographic maps for the primary drainage-basin characteristics used in the regression equations are presented along with examples. Several of the primary drainage-basin characteristics used in the regression equations are map-scale dependent. Use of maps of scales other than the scales used to develop the equations may produce results that do not conform to the range of estimation accuracies listed for the equations.

Regression analyses of Pearson Type-III design-flood discharges and selected channel-geometry characteristics were used to develop both statewide and regional channelgeometry equations. On the basis of a geographic bias identified from the statewide regression residuals, two channel-geometry hydrologic regions were defined for Iowa relative to the Des Moines Lobe landform region. The significant channel-geometry characteristics identified for the statewide and regional regression equations included bankfull width and bankfull depth for natural channels unaffected by channelization, and activechannel width for stabilized channels affected by channelization. The regression coefficients for the statewide and regional channelgeometry equations indicated an increase in design-flood discharges with increasing magnitude in the values of each channelgeometry characteristic. The average standard errors of prediction for the statewide regression equations ranged from 41.0 to 68.4 percent and for the regional regression equations from 30.3 to 70.0 percent. The regional channel-geometry regression equations provided an improved estimation accuracy compared to the statewide regression equations, with the exception of the Region II active-channel regression equations developed for design floods having recurrence intervals of 25, 50, and 100 years. Guidelines for measuring the channel-geometry characteristics used in the statewide and regional regression equations are presented along with examples.

Procedures for applying the drainage-basin and channel-geometry regression equations vary and depend on whether the design-flood discharge estimate is for a site on an ungaged stream, an ungaged site on a gaged stream, or a gaged site. When both a drainage-basin and a channel-geometry regression-equation estimate are available for a stream site, a procedure is presented for determining a weighted average of the two flood estimates. The procedure for estimating a design-flood discharge for an 
ungaged site on a gaged stream is based on information from the Pearson Type-III estimate for the gaged site, and on information from either both flood-estimation methods, or from only one of the methods. At a gaged site, a weighted design-flood discharge is estimated from the Pearson Type-III estimate, and from either both flood-estimation methods, or from only one of the methods. Examples are provided for each of these procedures.

The drainage-basin and channel-geometry flood-estimation methods presented in this report each measure characteristics that are presumed to be independent of each other. The drainage-basin flood-estimation method is based on measurements of morphologic and climatic characteristics that are related to how water flows off the land. The drainage-basin method measures the varying flood potential at stream sites as defined by differences in basin size, topographic relief, stream development, and precipitation. The channel-geometry flood-estimation method, in contrast, is based on measurements of channel morphology that are assumed to be a function of streamflow discharges and sediment-load transport. The channel-geometry method measures the variability of floods that have actually occurred as defined by differences in channel width and depth.

The drainage-basin flood-estimation method developed in this study is similar to the regional flood-estimation method developed in a previous study because both methods estimate flood discharges on the basis of morphologic relations. While the standard errors of estimate for the drainage-basin equations in this study appear to be higher, a direct comparison cannot be made because of the different methodologies used to develop the equations.

The statewide drainage-basin and statewide channel-geometry regression equations presented in this report provide floodestimation methods that minimize the subjectivity in their application to the ability of the user to measure the characteristics. Although the user of the regional channelgeometry equations may still encounter a dilemma when a stream site is located within the transitional zone or when a stream crosses regional boundaries, application of the statewide channel-geometry equations may be utilized to preclude the regional subjectivity associated with estimating a design-flood discharge in this situation. Despite the greater variability in the error of measurement associated with the channel-geometry characteristics, the channel-geometry equations presented in this report are considered to be useful as a corroborative flood-estimation method with respect to the drainage-basin method.

The estimation accuracy of the drainagebasin regression equations possibly could be improved if drainage-basin characteristics were quantified from larger scale data. The drainage-basin characteristics quantified by the GIS procedure were limited to the 1:250,000and 1:100,000-scale digital cartographic data currently available for Iowa.

\section{REFERENCES}

Allen, D.M., 1971, Mean square error of prediction as a criterion for selecting prediction variables: Technometrics, v. 13, p. $469-475$.

Baker, D.G., and Kuehnast, E.L., 1978, Climate of Minnesota, part X--Precipitation normals for Minnesota, 1941-1970: Minnesota Agricultural Experiment Station Technical Bulletin 314, 15 p.

Choquette, A.F., 1988, Regionalization of peak discharges for streams in Kentucky: U.S. Geological Survey Water-Resources Investigations Report 87-4209, 105 p.

Dempster, G.R., Jr., 1983, Instructions for streamflow/basin characteristics file: U.S. Geological Survey National Water Data Storage and Retrieval System (WATSTORE), v. 4, chap. II, sec. A, 34 p.

Eash, D.A., 1993, A geographic information system procedure to quantify physical basin characteristics, in Harlin, J.M., and Lanfear, K.J., eds., Proceedings of the Symposium on Geographic Information Systems and Water Resources: American Water Resources Association Technical Publication Series TPS-93-1, p. 173-182. 
Fields, F.K., 1975, Estimating streamflow characteristics for streams in Utah using selected channel-geometry parameters: U.S. Geological Survey Water-Resources Investigations $34-74,19 \mathrm{p}$.

Guy, H.P., 1969, Laboratory theory and methods for sediment analysis: U.S. Geological Survey Techniques of WaterResources Investigations, book 5, chap. C-1, $58 \mathrm{p}$.

Hardison, C.H., 1971, Prediction error of regression estimates of streamflow characteristics at ungaged sites: U.S. Geological Survey Professional Paper 750-C, p. C228-C236.

Hedman, E.R., and Kastner, W.M., 1977, Streamflow characteristics related to channel geometry in the Missouri River basin: U.S. Geological Survey Journal of Research, v. 5, no. 3, p. 285-300.

Hershfield, D.M., 1961, Rainfall frequency atlas of the United States: Washington, D.C., U.S. Department of Commerce, Weather Bureau Technical Paper No. 40, 115 p.

Iman, R.L., and Conover, W.J., 1983, A modern approach to statistics: New York, Wiley and Sons, $497 \mathrm{p}$.

Interagency Advisory Committee on Water Data (IACWD), 1982, Guidelines for determining flood flow frequency: Hydrology Subcommittee Bulletin 17B, 28 p. and appendices.

Jacques, J.E., and Lorenz, D.L., 1988, Techniques for estimating the magnitude and frequency of foods in Minnesota: U.S. Geological Survey Water-Resources Investigations Report 87-4170, 48 p.

Kirby, W.H., 1981, Annual flood frequency analysis using U.S. Water Resources Council guidelines (Program J407): U.S. Geological Survey National Water Data Storage and Retrieval System (WATSTORE), v. 4, chap. I, sec. C, 57 p.

Koltun, G.F., and Roberts, J.W., 1990, Techniques for estimating flood-peak discharges of rural, unregulated streams in Ohio: U.S. Geological Survey Water-
Resources Investigations Report 89-4126, $68 \mathrm{p}$.

Lara, O.G., 1973, Floods in Iowa--Technical manual for estimating their magnitude and frequency: Iowa Natural Resources Council Bulletin 11, 56 p.

1987, Method for estimating the magnitude and frequency of floods at ungaged sites on unregulated rural streams in Iowa: U.S. Geological Survey Water-Resources Investigations Report 87-4132, $34 \mathrm{p}$.

Larimer, O.J., 1957, Drainage areas of Iowa streams: Iowa Highway Research Board Bulletin No. 7 (reprinted 1974), 439 p.

Majure, J.J., and Soenksen, P.J., 1991, Using a geographic information system to determine physical basin characteristics for use in flood-frequency equations, in Balthrop, B.H., and Terry, J.E., eds., U.S. Geological Survey National Computer Technology Meeting--Proceedings, Phoenix, Arizona, November 14-18, 1988: U.S. Geological Survey Water-Resources Investigations Report 90-4162, p. 31-40.

Mallows, C.L., 1973, Some comments on $\mathrm{Cp}$ : Technometrics, v. 15, p. 661-675.

Marquardt, D.W., 1970, Generalized inverses, ridge regression, biased linear estimation, and nonlinear estimation: Technometrics, $v$. 12 , p. 591-612.

Melton, M.A., 1957, An analysis of the relations among elements of climate, surface properties, and geomorphology: Office of Naval Research, Geography Branch, Columbia Univ. Dept. of Geology, New York, Technical Report 11, Project NR 389-042, $102 \mathrm{p}$.

Montgomery, D.C., and Peck, E.A., 1982, Introduction to linear regression analysis: New York, Wiley and Sons, 504 p.

Office of Water Data Coordination, 1978, Physical basin characteristics for hydrologic analysis, in National handbook of recommended methods for water-data acquisition: U.S. Geological Survey, Reston, Va., chap. 7, $38 \mathrm{p}$. 
Osterkamp, W.R., 1979, Variation of alluvialchannel width with discharge and character of sedimient: U.S. Geological Survey Water-Resources Investigations 79-15, $11 \mathrm{p}$.

Osterkamp, W.R., and Hedman, E.R., 1977, Variation of width and discharge for natural high-gradient stream channels: Water Resources Research, v. 13, no. 2, p. 256-258.

1982, Perennial-streamflow characteristics related to channel geometry and sediment in the Missouri River Basin: U.S. Geological Survey Professional Paper 1242, 37 p.

Parrett, Charles, Hull, J.A., and Omang, R.J., 1987, Revised techniques for estimating peak discharges from channel width in Montana: U.S. Geological Survey WaterResources Investigations Report 87-4121, $34 \mathrm{p}$.

Pickup, G., and Rieger, W.A., 1979, A conceptual model of the relationship between channel characteristics and discharge: Earth Surface Processes, v. 4, p. 37-42.

Prior, J.C., 1991, Landforms of Iowa: Iowa City, Iowa Department of Natural Resources, University of Iowa Press, $153 \mathrm{p}$.

Riggs, H.C., 1974, Flash flood potential from channel measurements: International Association of Scientific Hydrology Publication 112, Proceedings of Paris Symposium, p. 52-56.

Robbins, C.H., 1986, Techniques for simulating flood hydrographs and estimating flood volumes for ungaged basins in central Tennessee: U.S. Geological Survey Water-Resources Investigations Report 86-4192, 32 p.

Schwob, H.H., 1953, Iowa floods--Magnitude and frequency: Iowa Highway Research Board Bulletin 1, $171 \mathrm{p}$.

1966, Magnitude and frequency of Iowa floods: Iowa Highway Research Board Bulletin 28, parts I and II, $423 \mathrm{p}$.

Statware, Inc., 1990, Statit statistics reference manual, release 2.3X: Corvallis, Oregon, Statware, Inc., chap. 6, 50 p.
Stedinger, J.R., and Cohn, T.A., 1986, Flood frequency analysis with historical and paleoflood information: Water Resources Research, v. 22, no. 5, p. 785-793.

Strahler, A.N., 1952, Dynamic basis of geomorphology: Bulletin of the Geological Society of America, v. 63, p. 923-938.

1958, Dimensional analysis applied to fluvially eroded landforms: Bulletin of the Geological Society of America, v. 69, p. 279-300.

1964, Quantitative geomorphology of drainage basins and channel networks, in Chow, V.T., ed., Handbook of applied hydrology: New York, McGraw-Hill, p. 4-39--4-76.

Tasker, G.D., 1980, Hydrologic regression with weighted least squares: Water Resources Research, v. 16 , no. 6 , p. $1107-1113$.

Tasker, G.D., and Thomas, W.O., 1978, Flood frequency analysis with pre-record information: Journal of Hydraulics Division, American Society of Civil Engineers, v. 104, no. 12 , p. 249-259.

Wahl, K.L., 1976, Accuracy of channel measurements and the implications in estimating streamflow characteristics, in Modern Developments in Hydrometry: Padua, Italy, World Meteorological Organization, v. 2, p. 311-319.

1984, Evolution of the use of channel cross-section properties for estimating streamflow characteristics, in Meyer, E.L., ed., Selected papers in the hydrologic sciences 1984: U.S. Geological Survey Water-Supply Paper 2262, p. 53-66.

Waite, Paul, 1988, Iowa precipitation frequencies: Iowa Department of Agriculture and Land Stewardship, State Climatology Office, Climatology of Iowa Series 2 , revised, $42 \mathrm{p}$.

Webber, E.E., and Roberts, J.W., 1981, Floodflow characteristics related to channel geometry in Ohio: U.S. Geological Survey Open-File Report 81-1105, 28 p. 


\section{APPENDIX A}

\section{Selected Drainage-Basin Characteristics Quantified Using a Geographic- Information-System Procedure}

$\left[{ }^{*}\right.$, A primary drainage-basin characteristic used in the regression equations (table 2); superscripts $^{\mathrm{a}-\mathrm{n}}$, footnotes at end of the appendix reference the literary and data source for each drainage-basin characteristic and list topographic-map scales to use for manual measurements of primary drainage-basin characteristics used in the regression equations]

\section{Basin-Area Measurements}

$T D A^{*} \quad$ - Total drainage area ${ }^{\mathrm{a}}$, in square miles $^{\mathrm{b}}$, includes noncontributing areas.

$N C D A^{*}$ - Noncontributing drainage area ${ }^{\mathrm{a}}$, in square miles ${ }^{\mathrm{b}}$, total area that does not contribute to surface-water runoff at the basin outlet.

\section{Basin-Length Measurements}

$B L \quad-$ Basin length $^{\mathrm{c}}$, in miles ${ }^{\mathrm{b}}$, measured along the main-channel, flood-plain valley from basin outlet to basin divide.

$B P^{*} \quad$ - Basin perimeter ${ }^{\mathrm{a}}$, in miles ${ }^{\mathrm{b}}$, measured along entire drainage-basin divide.

\section{Basin-Relief Measurements}

$B S$

- Average basin slope ${ }^{a}$, in feet per mile $e^{b, d}$, measured by the "contour-band" method, within the contributing drainage area $(C D A)$,

$$
B S=\frac{\text { (total length of all selected elevation contours) (contour interval) }}{C D A} .
$$

$B R^{*} \quad-$ Basin relief ${ }^{\mathrm{e}}$, in feet ${ }^{\mathrm{d}, \mathrm{f}}$, measured as the sea-level elevation difference between the highest contour elevation and the lowest interpolated elevation at basin outlet within the CDA.

\section{Basin Computations}

$C D A$ - Contributing drainage area ${ }^{a}$, in square miles, defined as the total area that contributes to surface-water runoff at the basin outlet,

$$
C D A=T D A-N C D A \text {. }
$$

$B W \quad$ - Effective basin width ${ }^{\mathrm{a}}$, in miles,

$$
B W=\frac{C D A}{B L} .
$$

SF - Shape factor ${ }^{\mathrm{a}}$, dimensionless, ratio of basin length to effective basin width,

$$
S F=\frac{B L}{B W} \text {. }
$$

ER - Elongation ratio ${ }^{\mathrm{a}}$, dimensionless, ratio of (1) the diameter of a circle of area equal to that of 
the basin to (2) the length of the basin,

$$
E R=\left[\frac{4 C D A}{\pi(B L)^{2}}\right]^{0.5}=1.13\left(\frac{1}{S F}\right)^{0.5} .
$$

$R B \quad-$ Rotundity of basin ${ }^{\mathrm{a}}$, dimensionless,

$$
R B=\frac{\pi(B L)^{2}}{4 C D A}=0.785 S F .
$$

CR - Compactness ratio ${ }^{\mathrm{a}}$, dimensionless, is the ratio of the perimeter of the basin to the circumference of a circle of equal area,

$$
C R=\frac{B P}{2(\pi C D A)^{0.5}}
$$

$R R \quad-$ Relative relief ${ }^{\mathrm{e}}$, in feet per mile,

$$
R R=\frac{B R}{B P}
$$

\section{Channel- (Stream-) Length Measurements}

MCL - Main-channel length ${ }^{\mathrm{a}}$, in miles $^{\mathrm{g}}$, measured along the main channel from the basin outlet to the basin divide.

TSL - Total stream length ${ }^{\mathrm{e}}$, in miles $^{\mathrm{g}}$, computed by summing the length of all stream segments within the $C D A$.

\section{Channel-Relief Measurement}

MCS - Main-channel slope ${ }^{\mathrm{a}}$, in feet per mile, an index of the slope of the main channel computed from the difference in streambed elevation ${ }^{d}$ at points 10 percent and 85 percent of the distance $^{g}$ along the main channel from the basin outlet to the basin divide,

$$
M C S=\frac{\left(E_{85}-E_{10}\right)}{0.75 M C L}
$$

\section{Channel (Stream) Computations}

MCSR - Main-channel sinuosity ratio ${ }^{\mathrm{a}}$, dimensionless,

$$
M C S R=\frac{M C L}{B L} .
$$

$S D \quad-$ Stream density ${ }^{\mathrm{a}}$, in miles per square mile, within the $C D A$,

$$
S D=\frac{T S L}{C D A} \text {. }
$$

CCM - Constant of channel maintenance ${ }^{\mathrm{a}}$, in square miles per mile, within the $C D A$, 


$$
C C M=\frac{C D A}{T S L}=\frac{1}{S D}
$$

MCSP - Main-channel slope proportion ${ }^{\mathrm{h}}$, dimensionless,

$$
M C S P=\frac{M C L}{(M C S)^{0.5}}
$$

RN - Ruggedness number ${ }^{\mathrm{i}}$, in feet per mile,

$$
R N=\frac{(T S L)(B R)}{C D A}=(S D)(B R)
$$

$S R$ - Slope ratio of main-channel slope to basin slope ${ }^{\mathrm{e}}$, dimensionless, within the $C D A$,

$$
S R=\frac{M C S}{B S} \text {. }
$$

\section{First-Order Streams Measurement}

FOS ${ }^{*} \quad$ - Number of first-order streams within the $C D A^{\mathrm{j}, g, \mathrm{k}}$, using Strahler's method of ordering streams.

\section{Drainage-Frequency Computation}

$D F \quad$ - Drainage frequency ${ }^{\mathrm{e}}$, in number of first-order streams per square mile, within the $C D A$,

$$
D F=\frac{F O S}{C D A}
$$

\section{Climatic Measurements}

AP - Mean annual precipitation ${ }^{\mathrm{c}}$, in inches ${ }^{\mathrm{l}}$, computed as a weighted average within the TDA.

$T T F^{*} \quad$ - 2-year, 24-hour precipitation intensity ${ }^{\mathrm{c}}$, in inches ${ }^{\mathrm{m}, \mathrm{n}}$, defined as the maximum 24-hour precipitation expected to be exceeded on the average once every 2 years, computed as a weighted average within the TDA.

aModified from Office of Water Data Coordination (1978, p. 7-9 - 7-16).

${ }^{b}$ Measured from 1:250,000-scale U.S. Defense Mapping Agency topographic maps.

${ }^{c}$ Modified from National Water Data Storage and Retrieval System (Dempster, 1983, p. A-24--A-26).

${ }^{\mathrm{d}}$ Measured from 1:250,000-scale U.S. Defense Mapping Agency digital elevation model sea-level data.

eModified from Strahler (1958, p. 282-283).

fUse 1:250,000-scale U.S. Defense Mapping Agency topographic maps for manual measurements.

g Measured from 1:100,000-scale U.S. Geological Survey digital line graph data. 
${ }^{h}$ Modified from Robbins (1986, p. 12).

${ }^{i}$ Modified from Melton (1957).

${ }^{j}$ Modified from Strahler (1952).

${ }^{k}$ Use 1:100,000-scale U.S. Geological Survey topographic maps (County Map Series) for manual measurements.

'Determined from Iowa Department of Agriculture and Land Stewardship, State Climatology Office (Des Moines), and from Baker and Kuehnast (1978); mean annual precipitation maps.

mDetermined from Waite (1988, p. 31) and Hershfield (1961, p. 95); 2-year, 24-hour precipitation intensity maps.

${ }^{\mathrm{n}}$ Use figure 5 for manual measurements. 


\section{APPENDIX B}

\section{Techniques for Manual, Topographic-Map Measurements of Primary Drainage-Basin Characteristics Used in the Regression Equations}

The drainage-basin flood-estimation method is applicable to unregulated rural stream sites in Iowa with drainage areas less than $1,060 \mathrm{mi}^{2}$. Specific information concerning techniques for making manual measurements is outlined for the six primary drainage-basin characteristics that are used to calculate the four basin characteristics listed in the regression equations in table 2 . Comparisons between manual measurements made from different scales of topographic maps are shown in table 7 for four of these six-primary drainage-basin characteristics. Table 7 demonstrates that several of these primary drainage-basin characteristics are map-scale dependent. Map-scale dependency refers to a condition whereby a drainage-basin characteristic value is affected substantially by the scale of topographic map used in the measurement. The comparisons in table 7 list the percentage differences between manual measurements made at the same scale used for geographicinformation-system (GIS) measurements (the base scale) and manual measurements made at different scales. Use of maps of scales other than the scales used to develop the equations may produce results that do not conform to the range of estimation accuracies listed for the equations in table 2. The scale of map to use for manual measurements of each primary drainage-basin characteristic is outlined in this section and in the footnotes at the end of Appendix A.

\section{Total Drainage Area (TDA)}

The stream site is located and the drainage-divide boundary upstream of the site is delineated on 1:250,000-scale U.S. Defense Mapping Agency (DMA) topographic maps. The drainage-divide boundary is delineated along the topographic divide that directs surface-water runoff from precipitation to the basin outlet located at the stream site. The drainage-divide boundary is an irregular line that traces the perimeter of the drainage area and is perpendicular to each elevation contour that it crosses (Office of Water Data Coordination, 1978, p. 7-9-7-10). In some cases it may be difficult to delineate the drainage-divide boundary on 1:250,000-scale topographic maps, particularly for small drainage basins or for drainage basins located in areas of low relief. In such cases it may be necessary to use larger scale topographic maps, such as 1:100,000-scale or 1:24,000-scale maps, to facilitate the delineation. Figure $4 A$ shows the drainage-divide boundary for the Black Hawk Creek at Grundy Center streamflow-gaging station (station number 05463090; map number 73 , fig. 1 ).

Because GIS measurements of total drainage area were quantified from 1:250,000-scale topographic maps, the appropriate scale for manual measurements of total drainage area is 1:250,000. Total drainage areas for many Iowa stream sites are listed in "Drainage Areas of Iowa Streams" (Larimer, 1957). The total drainage areas listed in this publication can be used to calculate contributing drainage area $(C D A)$ once any necessary adjustments for noncontributing drainage areas $(N C D A)$ are accounted for. Manual measurements of total drainage area for stream sites typically are planimetered or digitized from topographic maps if drainage areas are not listed in Larimer's (1957) publication.

\section{Noncontributing Drainage Area (NCDA)}

Noncontributing drainage areas usually are identified as either an area of internal drainage or as an area draining into a disappearing stream. Internal drainage areas drain into depressions, which are represented by hachured contour lines on topographic maps. Internal drainage areas may include potholes or marshes, which are common within the Des Moines Lobe landform region in north-central Iowa (Region II, fig. 2). Disappearing streams do not connect with the drainage network that reaches the basin outlet. In the karst topography of northeast Iowa, sinkholes are a common cause of disappearing streams. 


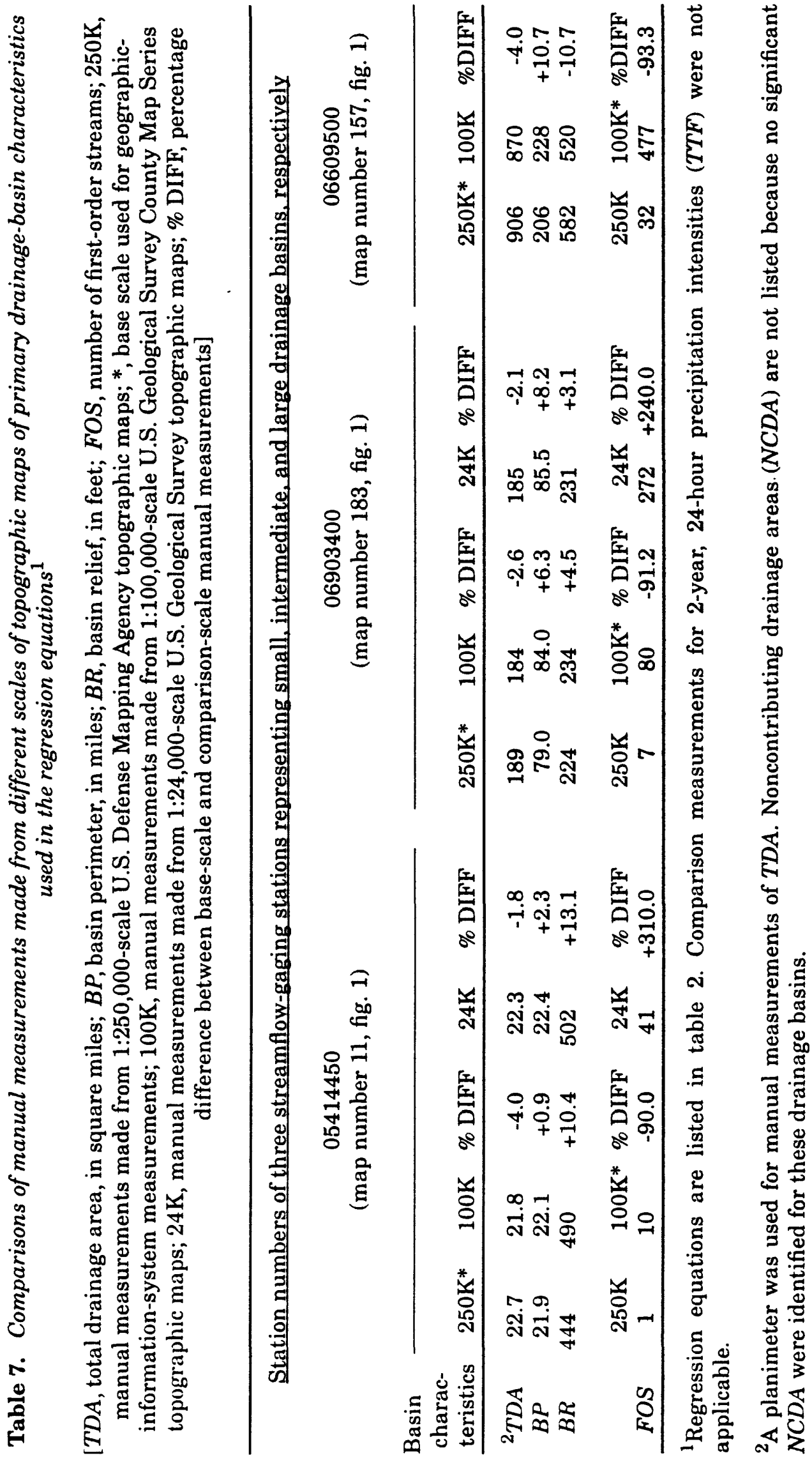


Noncontributing drainage areas are delineated on 1:250,000-scale topographic maps. When questionable noncontributing drainage areas are encountered, hydrologic judgment is required to determine whether to delineate these areas as noncontributing. Larger scale topographic maps facilitate the delineation of questionable noncontributing areas.

\section{Basin Perimeter (BP)}

The basin perimeter is measured along the drainage-divide boundary delineated on 1:250,000-scale topographic maps. Because GIS measurements of basin perimeter were quantified from 1:250,000-scale topographic maps, the appropriate scale for manual measurements is $1: 250,000$.

\section{Basin Relief $(B R)$}

Basin relief is the difference between the maximum elevation contour and the minimum interpolated elevation within the contributing drainage area delineated on 1:250,000-scale topographic maps. The minimum basin elevation is defined at the basin outlet as an interpolated elevation between the first elevation contour crossing the main channel upstream of the basin outlet and the first elevation contour crossing the main channel downstream of the basin outlet. Because GIS measurements of basin relief were quantified from 1:250,000-scale digital elevation model (DEM) data, the appropriate scale for manual measurements is $1: 250,000$. Figure $4 C$ shows the elevation contours created from DEM data for the Black Hawk Creek at Grundy Center drainage basin.

\section{Number of First-Order Streams (FOS)}

The number of first-order streams is a count of all the stream segments defined as being a first-order drainage using Strahler's method of ordering streams (Strahler, 1952). First-order streams are defined for contributing drainage areas on 1:100,000-scale topographic maps. Figure $4 B$ shows the stream ordering for the Black Hawk Creek at Grundy Center drainage basin. As shown in figure $4 B$, a stream segment with no tributaries is defined as a first-order stream. Where two first-order streams join, they form a second-order stream; where two second-order streams join, they form a third-order stream; and so forth. Because GIS measurements of the number of first-order streams were quantified from 1:100,000-scale digital line graph data, the appropriate scale for manual measurements is $1: 100,000$. Comparison measurements listed in table 7 indicate that the number of first-order streams is clearly map-scale dependent and use of map scales other than 1:100,000 may produce results that do not conform to the range of estimation accuracies listed for the equations in table 2.

\section{2-Year, 24-Hour Precipitation Intensity (TTF)}

The map shown in figure 5 is used to calculate 2-year, 24-hour precipitation intensities for drainage basins in Iowa and for basins that extend into southern Minnesota. This map shows polygon areas that represent averages for maximum 24-hour precipitation intensities, in inches, that are expected to be exceeded on the average once every 2 years. These polygons were created from the precipitation contours depicted on 2-year, 24-hour precipitation intensity maps for Iowa (Waite, 1988 , p. 31) and the United States (Hershfield, 1961, p. 95). The polygon areas for southern Minnesota were interpolated from the precipitation contours depicted on the United States map. The polygons shown in figure 5 represent the average value, in inches, of rainfall between the precipitation contours and are not intended to represent interpolated values between the contours. Figure 5 was used to compute a weighted average of the 2-year, 24-hour precipitation intensity for each drainage basin processed by the GIS procedure. A manual measurement of 2-year, 24-hour precipitation intensity can be made by delineating the approximate location of the drainage-divide boundary for a stream site in figure 5 . The approximate percentage of the total drainage area for the 
stream site that falls within each precipitation polygon shown in figure 5 is calculated, and a weighted average for the basin is computed as

$$
T T F=\left(A_{1}\right)\left(T T F_{1}\right)+\left(A_{2}\right)\left(T T F_{2}\right)+\ldots+\left(A_{p}\right)\left(T T F_{p}\right),
$$

where $T T F$ is the weighted average for 2-year, 24-hour precipitation intensity, in inches;

$A_{\mathrm{i}}$ is the approximate percentage of the total drainage area of a basin within the ith 2-year, 24-hour precipitation intensity polygon shown in figure $5(\mathrm{i}=1, \ldots, \mathrm{p})$;

$T T F_{\mathrm{i}}$ is the 2-year, 24-hour precipitation intensity, in inches, for the ith polygon shown in figure $5(\mathrm{i}=1, \ldots, \mathrm{p})$; and

$\mathrm{p}$ is the total number of 2-year, 24-hour precipitation intensity polygons shown in figure 5 overlain by the drainage-divide boundary of a basin.

For example, if approximately 70 percent of the total drainage area for a stream site overlies the polygon labeled as $3.15 \mathrm{in}$. and approximately 30 percent of the total drainage area overlies the polygon labeled 3.05 in., then the weighted average for the basin is calculated as

$$
\begin{aligned}
T T F & =\left(A_{1}\right)\left(T T F_{1}\right)+\left(A_{2}\right)\left(T T F_{2}\right), \\
& =(0.70)(3.15)+(0.30)(3.05), \\
& =3.12 \mathrm{in} .
\end{aligned}
$$




\section{APPENDIX C}

\section{Procedure for Conducting Channel-Geometry Measurements}

The channel-geometry flood-estimation method is applicable to stream sites in Iowa with unregulated and stabilized stream channels. The following discussion outlines the procedure for conducting channel-geometry measurements.

\section{Selection of Channel-Geometry Measurement Reaches}

An inspection of $1: 100,000$ - or 1:24,000-scale topographic maps is made to evaluate the channel reach both upstream and downstream of the stream site. Channel-geometry measurements are made along a straight channel reach, and an inspection of topographic maps is helpful in determining whether to start searching upstream or downstream of the site for a measurement reach. If the channel for some distance upstream and downstream of the stream site is very sinuous, unnaturally wide, or in an area that may be affected by development, topographic maps can be inspected to locate more suitable channel reaches at nearby bridges upstream or downstream of the stream site.

Channel-geometry measurements can be made at some distance away from the stream site, either upstream or downstream, as long as the drainage area upstream of the measurement reach does not change by more than about 5 percent from the drainage area of the stream site. The 5-percent change in drainage area is an approximate limitation to ensure that channel-geometry measurements are representative of the streamflow discharges that occur at the stream site.

Topographic maps are useful in identifying linear channels that are usually indicative of channelization. Channels that appear to be channelized are noted because application of the channel-geometry equations listed in tables 3-5 are dependent on whether a stream has been channelized. A visual inspection of the channel also is made upon visiting the stream site to check for evidence of channelization. Features that are characteristic of channelized streams are illustrated in figure $7 D$, which shows the straightened and leveed channel reach downstream of the Big Creek near Varina gaging station (station number 05482170; map number 108, fig. 2). If evidence of channelization is not found, then the bankfull equations (the first set of equations listed in tables 3-5) are applicable; if evidence of channelization is found, then the active-channel equations (the second set of equations listed in tables 3-5) may be applicable.

The channel-geometry method may not be applicable to poorly drained or pooled streams that have extremely low, local gradients (less than approximately $0.1 \mathrm{ft} / \mathrm{mi}$.). A local gradient is measured from 1:24,000-scale topographic maps and is calculated as the slope of the channel between the nearest contour lines crossing the channel upstream and downstream of a stream site. This slope measurement is performed only for those stream sites that are suspected of having extremely low, local gradients and typically is not required for channel-geometry measurements.

\section{Selection of Channel-Geometry Measurement Sections}

Measurements of channel-geometry characteristics are made at channel cross sections that represent stable and self-formed channel-bank conditions. Self-formed channels are natural channels or channels that have been affected by channelization for which at least the active-channel portion of the channel has had time to adjust back to natural conditions. Commonly, the active-channel portion of the channel will adjust back to natural or self-formed conditions within approximately 5 to 10 years after channelization occurs.

Measurements are made far enough away from bridges or other structures crossing the stream channel to avoid any alterations to the channel caused by construction. More distance is allowed downstream of bridges to avoid the effects of the channel constriction and more distance is allowed upstream of culverts to avoid the effects of backwater. Ideally, measurements are made in a 
As shown in figure 6, the active-channel reference level is identified at a lower channel-bank elevation. At least three active-channel width measurements are made that are within 10 percent of the average, and active-channel measurement sections are separated by at least twice the active-channel width. The tagline or tape is staked in a similar manner as previously described, and width measurements are read to at least two significant figures. As defined by Osterkamp and Hedman (1977, p. 256),

"The active channel is a short-term geomorphic feature subject to change by prevailing discharges. The upper limit is defined by a break in the relatively steep bank slope of the active channel to a more gently sloping surface beyond the channel edge. The break in slope normally coincides with the lower limit of permanent vegetation so that the two features, individually or in combination, define the active channel reference level. The section beneath the reference level is that portion of the stream entrenchment in which the channel is actively, if not totally, sculptured by the normal process of water and sediment discharge."

Figures $7 A$ and $7 E$ show photographs at two stream sites where a tape and a tagline, respectively, were staked at the active-channel reference level used to measure active-channel widths. 


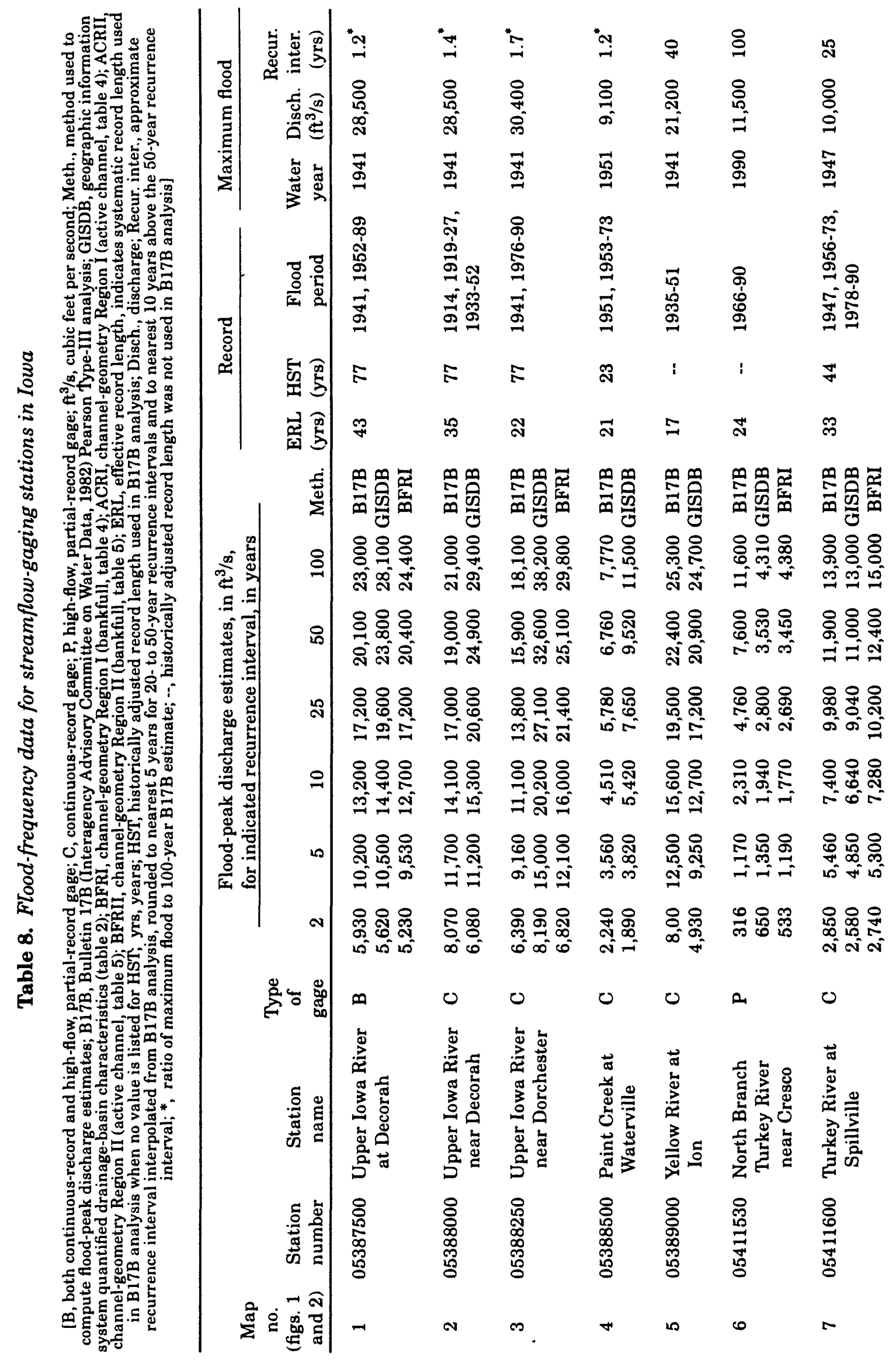




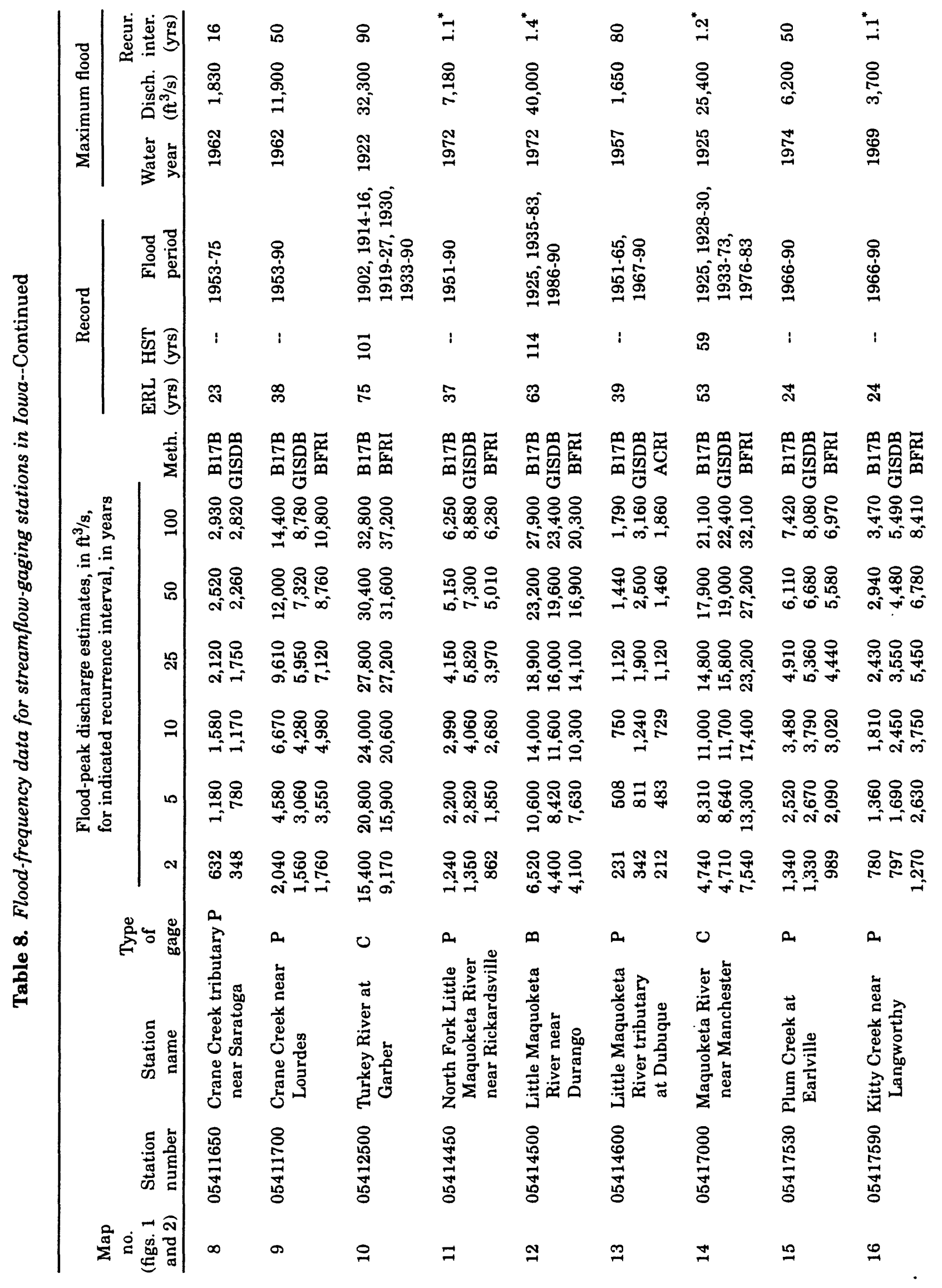




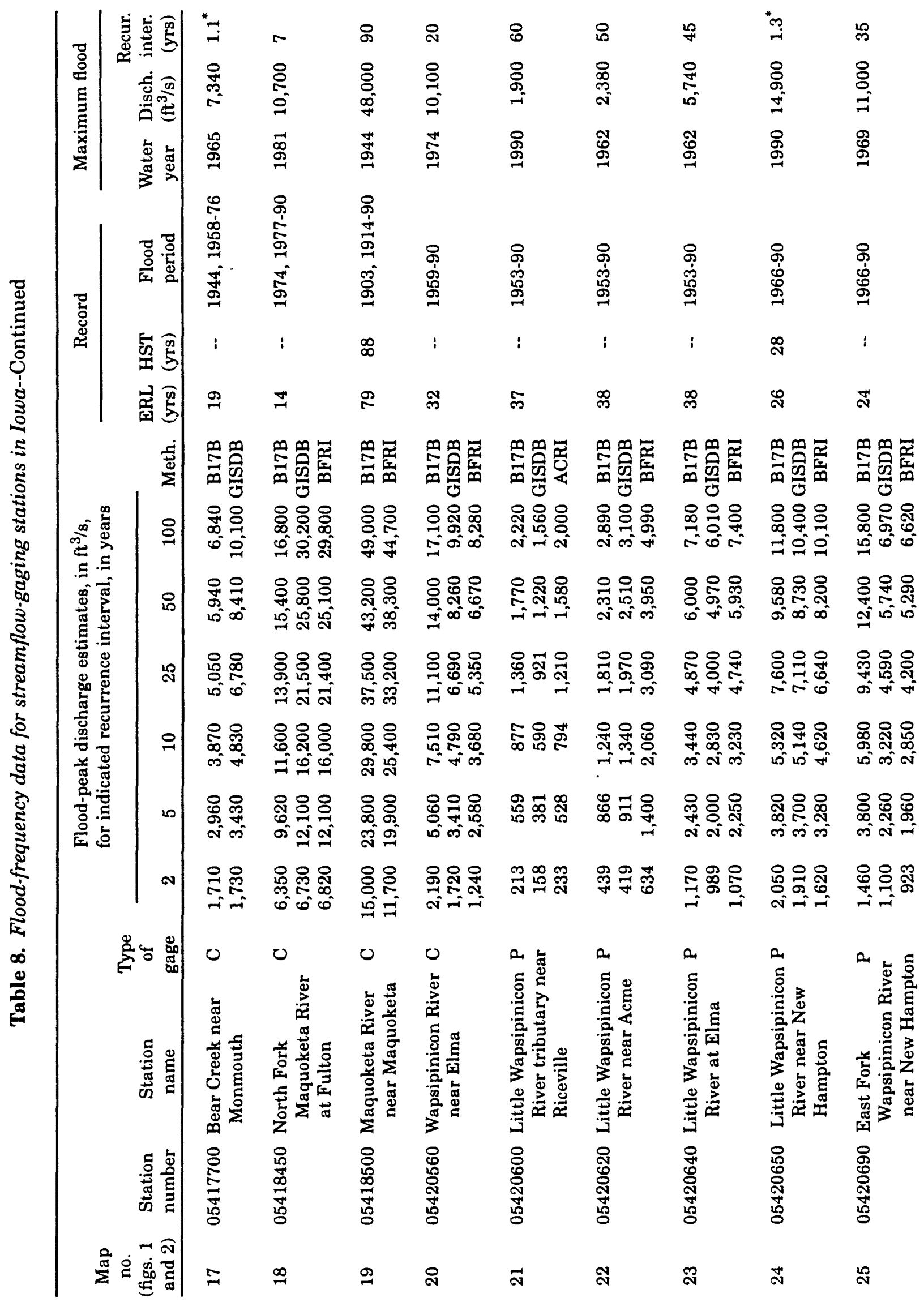




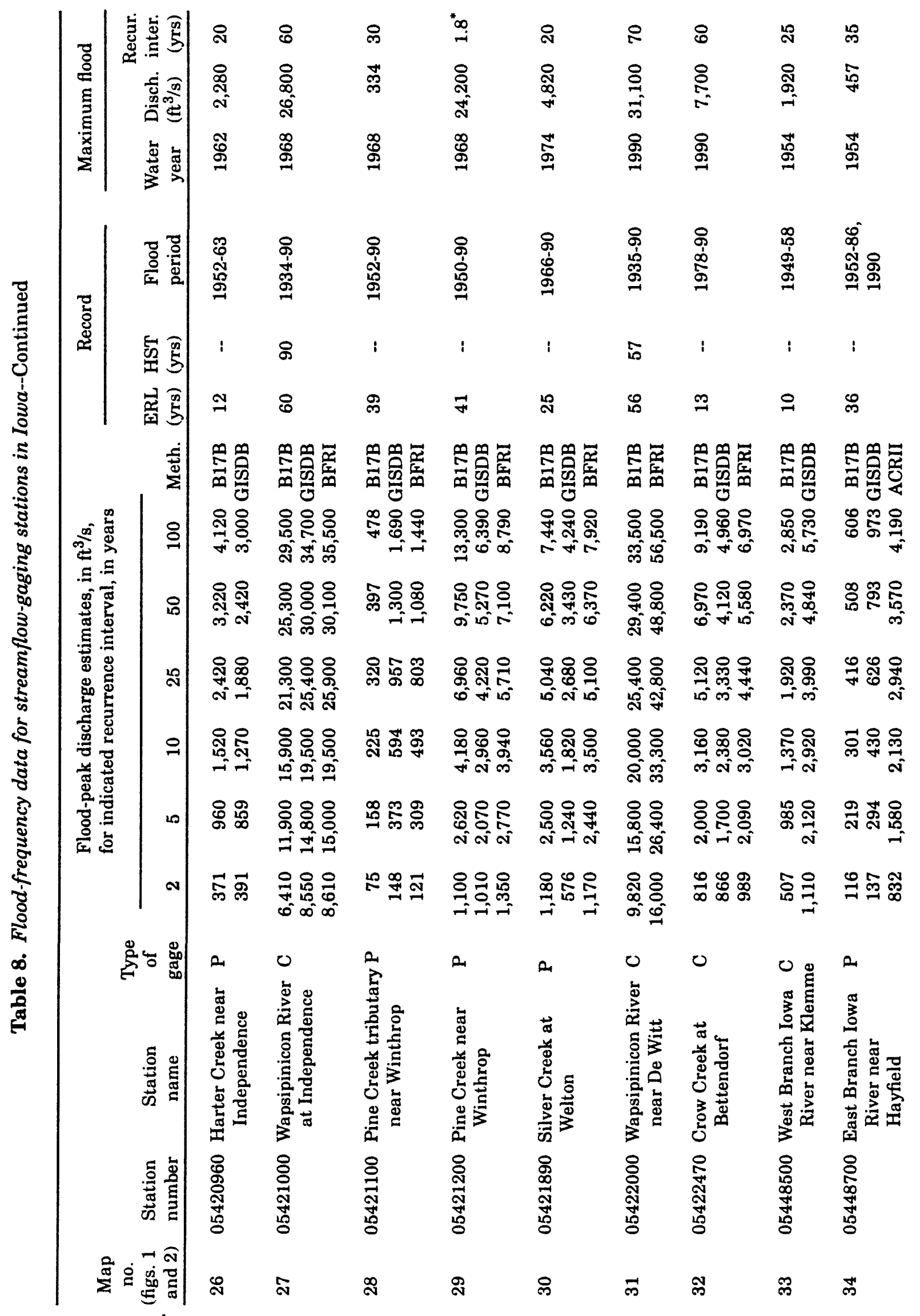




\begin{tabular}{|c|c|c|c|c|c|c|c|c|c|}
\hline & 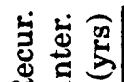 & \& & ㅇ & $\stackrel{*}{*}$ & 8 & "ับ & مَّ" & $\exists$ & 오 \\
\hline 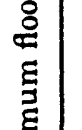 & 离商 & $\begin{array}{l}8 \\
\& \\
\text { wi }\end{array}$ & $\underset{8}{\mathscr{8}}$ & $\begin{array}{l}8 \\
8 \\
\text { พิ }\end{array}$ & 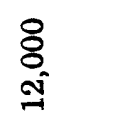 & ఫ్ & $\begin{array}{l}\stackrel{8}{\sharp} \\
=\end{array}$ & 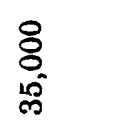 & $\stackrel{8}{\circ}$ \\
\hline 离 & 兽 & 范 & 芯 & $\stackrel{\infty}{a}$ & ๙ิ & సั & ๙ू. & 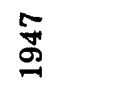 & 怘 \\
\hline D & 踪: & 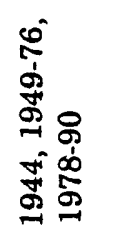 & 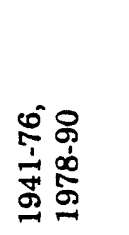 & 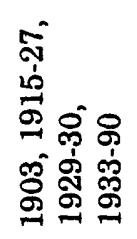 & 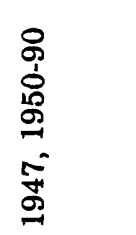 & $\begin{array}{l}8 \\
8 \\
0 \\
0 \\
0 \\
\infty \\
0 \\
0 \\
0\end{array}$ & 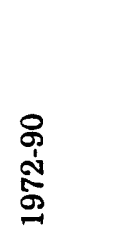 & 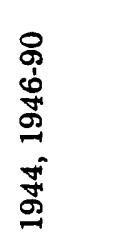 & 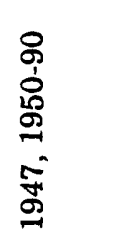 \\
\hline జٌ & $\begin{array}{l}\text { 空 } \\
\text { 品 }\end{array}$ & 1 & ! & 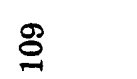 & $\underset{+}{*}$ & 1 & $\mathscr{F}$ & 5 & $\mathscr{2}$ \\
\hline & 虽兽 & $\not{\not}$ & $\mathscr{F}$ & $\approx$ & $\underset{\mathcal{F}}{ }$ & $\vec{\nabla}$ & ส & $\mathscr{H}$ & $\stackrel{\mathcal{F}}{\mathcal{F}}$ \\
\hline की & 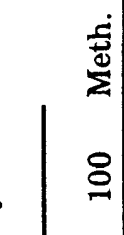 & 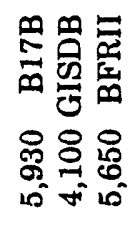 & 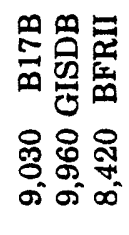 & 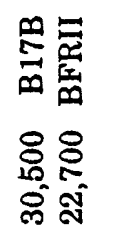 & 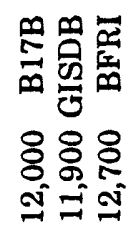 & 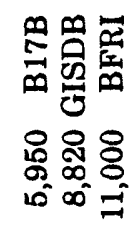 & 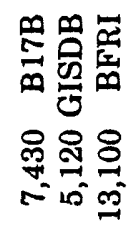 & 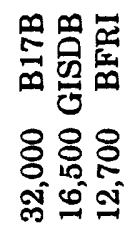 & 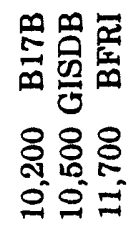 \\
\hline 要 & 요 & 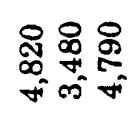 & 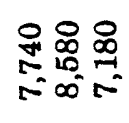 & 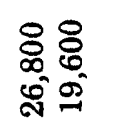 & 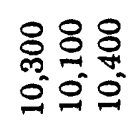 & 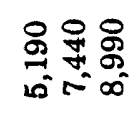 & 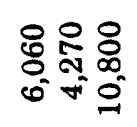 & 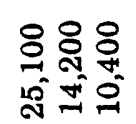 & 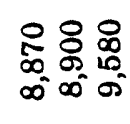 \\
\hline 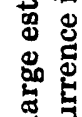 & $\stackrel{\text { ง }}{\text { }}$ & 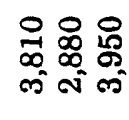 & 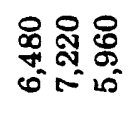 & $\begin{array}{l}88 \\
80 \\
010 \\
\text { มิ }\end{array}$ & 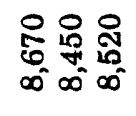 & 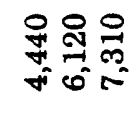 & 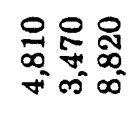 & 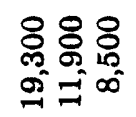 & 通串 \\
\hline 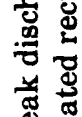 & 으 & 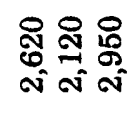 & 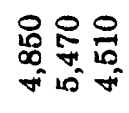 & $\begin{array}{l}8.8 \\
80 \\
\infty \\
01\end{array}$ & 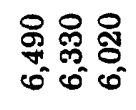 & 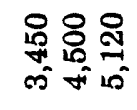 & 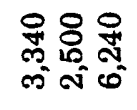 & 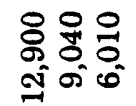 & 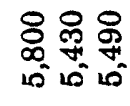 \\
\hline 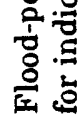 & مـا & 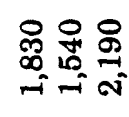 & 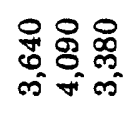 & $\begin{array}{l}80 \\
80 \\
\pm 0 \\
\pm 10\end{array}$ & 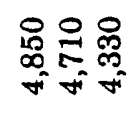 & 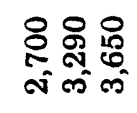 & 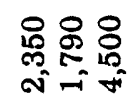 & 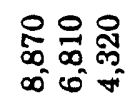 & 융요용 \\
\hline & N & $\stackrel{\infty}{\infty} \underset{\infty}{\infty} \stackrel{0}{=}$ & 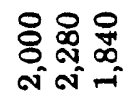 & $\begin{array}{l}\text { 용 } \\
\text { î. } \\
\infty \\
\infty\end{array}$ & 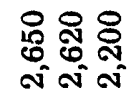 & 웅오요 & 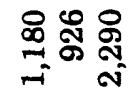 & 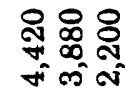 & 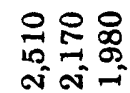 \\
\hline & 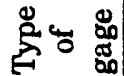 & 0 & 0 & 0 & U & 0 & D & 0 & 0 \\
\hline & 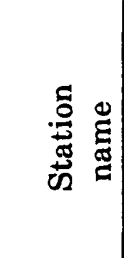 & 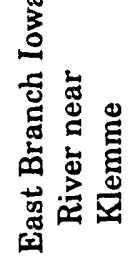 & 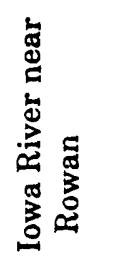 & 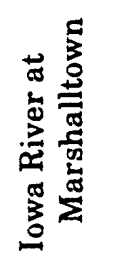 & 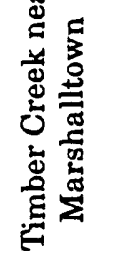 & 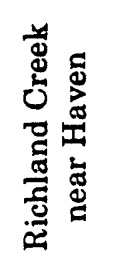 & 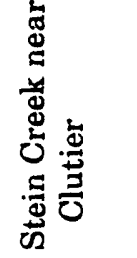 & 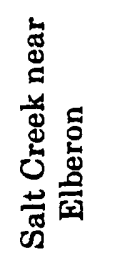 & 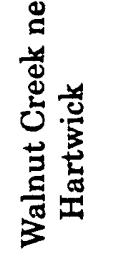 \\
\hline & 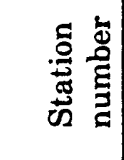 & 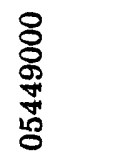 & 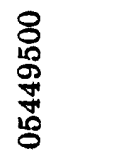 & $\begin{array}{l}8 \\
6 \\
50 \\
\frac{10}{0} \\
0\end{array}$ & 总 & $\begin{array}{l}8 \\
\frac{8}{10} \\
\frac{10}{4} \\
\frac{10}{0}\end{array}$ & 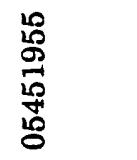 & 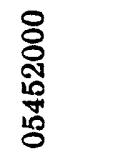 & 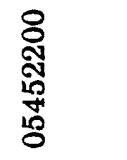 \\
\hline & 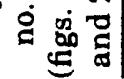 & "ొ & $\stackrel{\mathscr{m}}{\mathscr{m}}$ & $\tilde{\infty}$ & 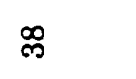 & 尺్లి & 우 & $\vec{\nabla}$ & พ \\
\hline
\end{tabular}




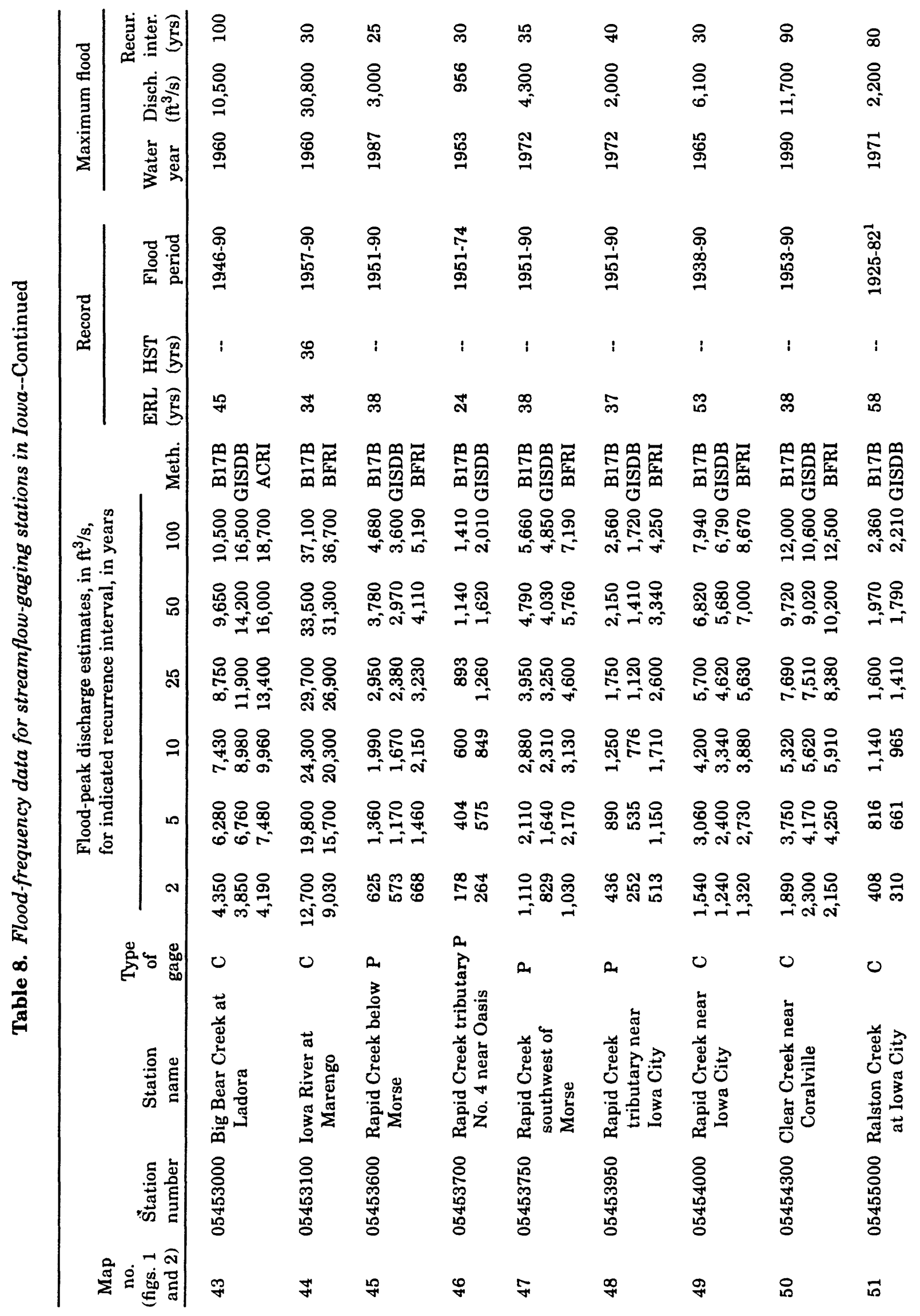




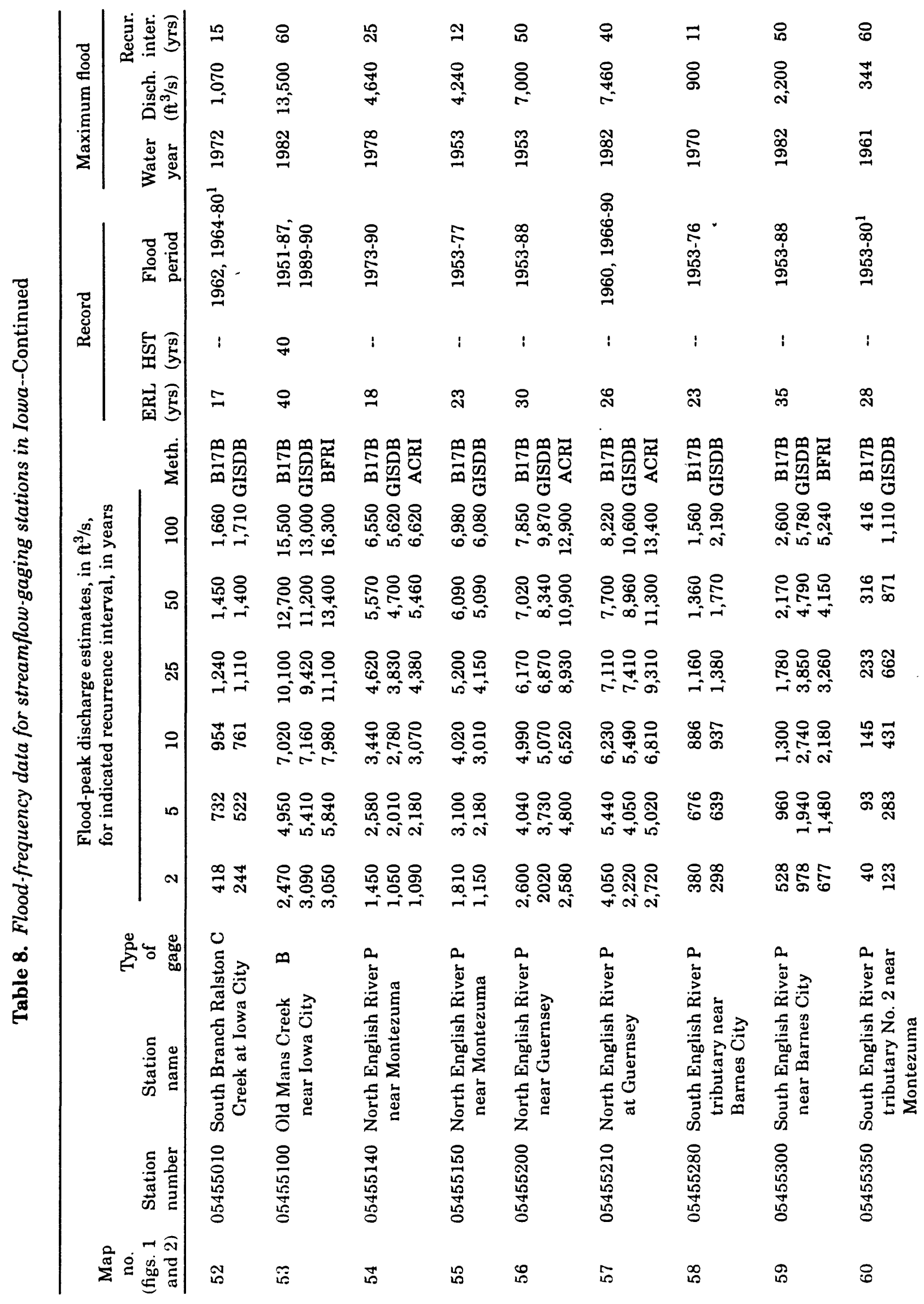




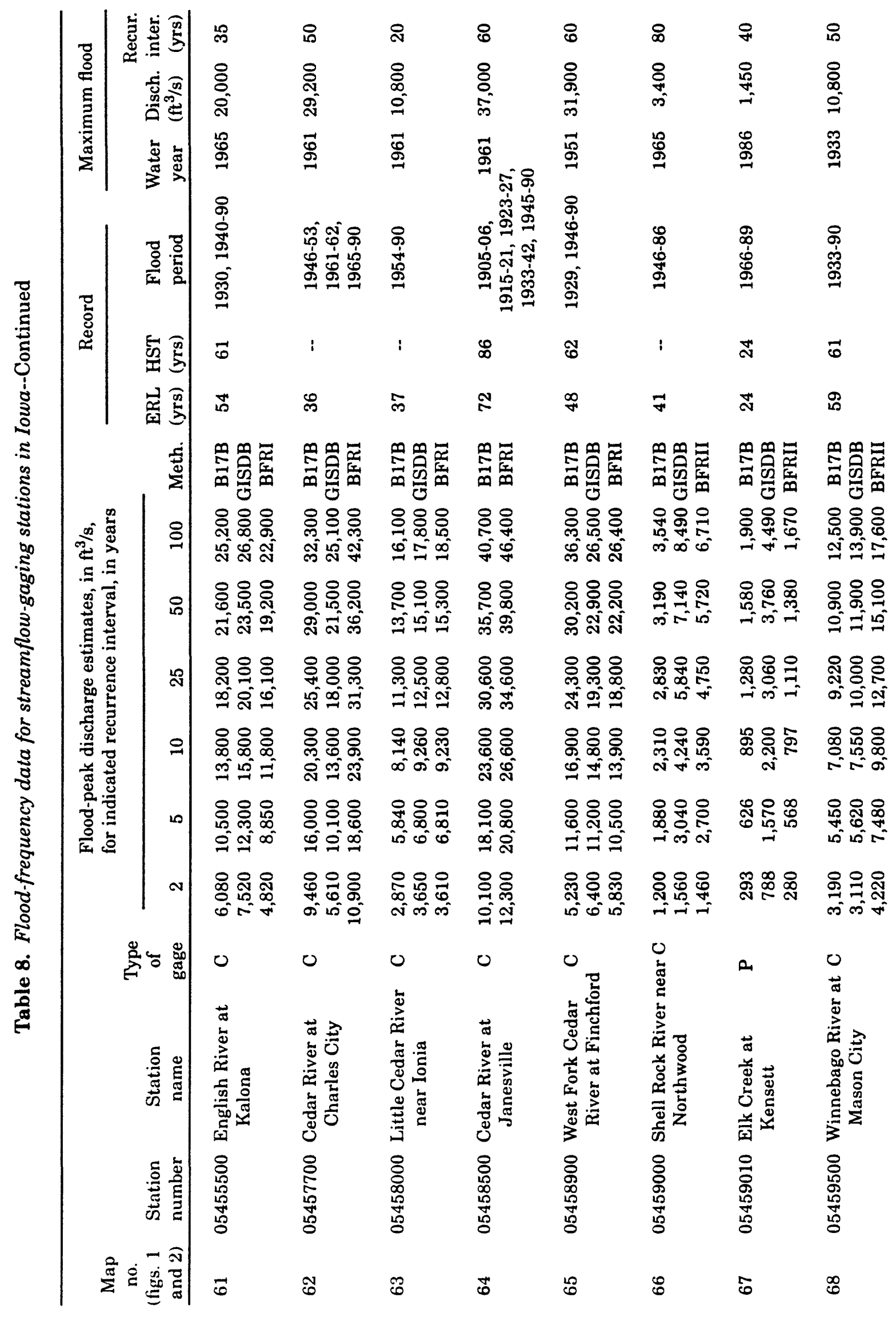




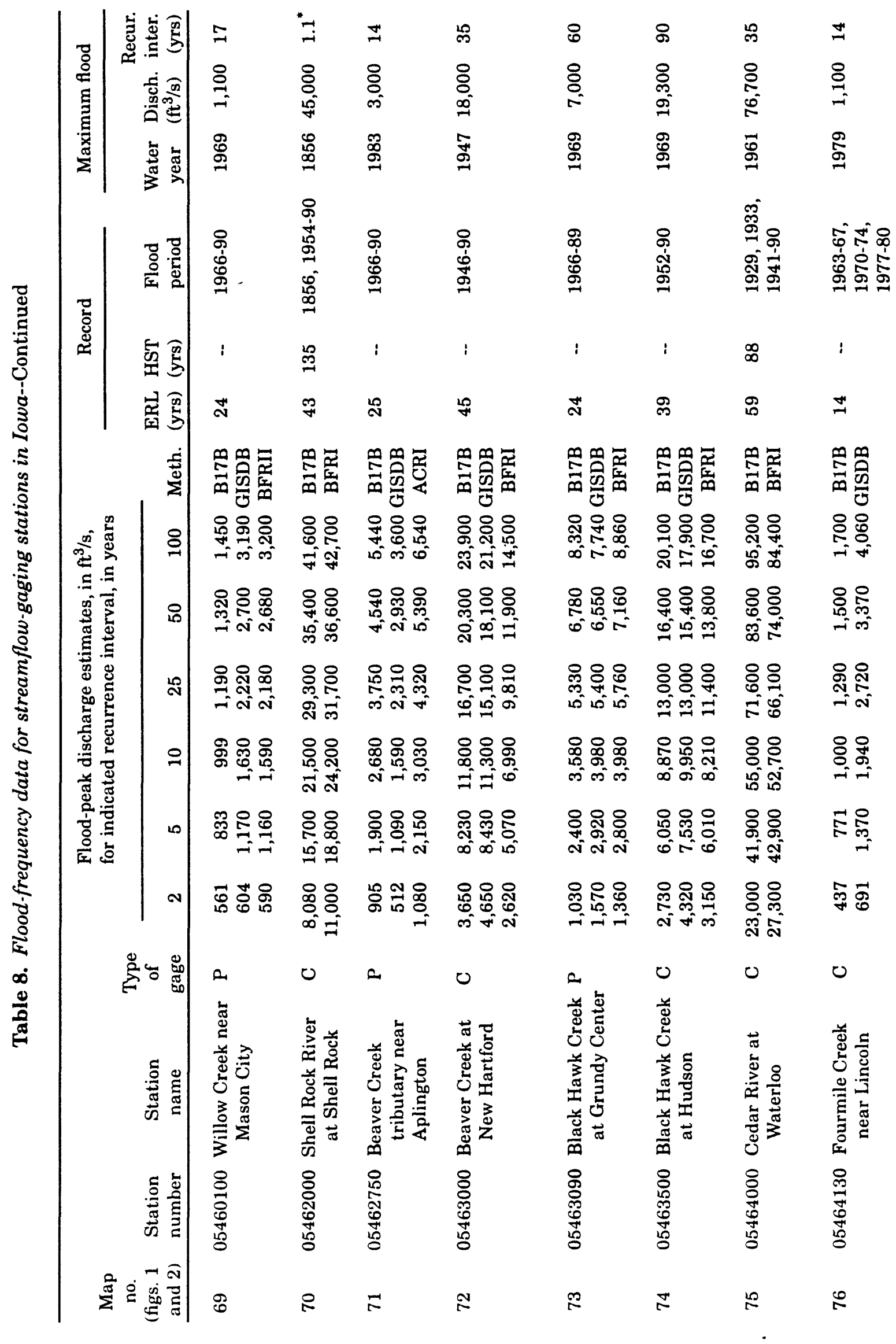









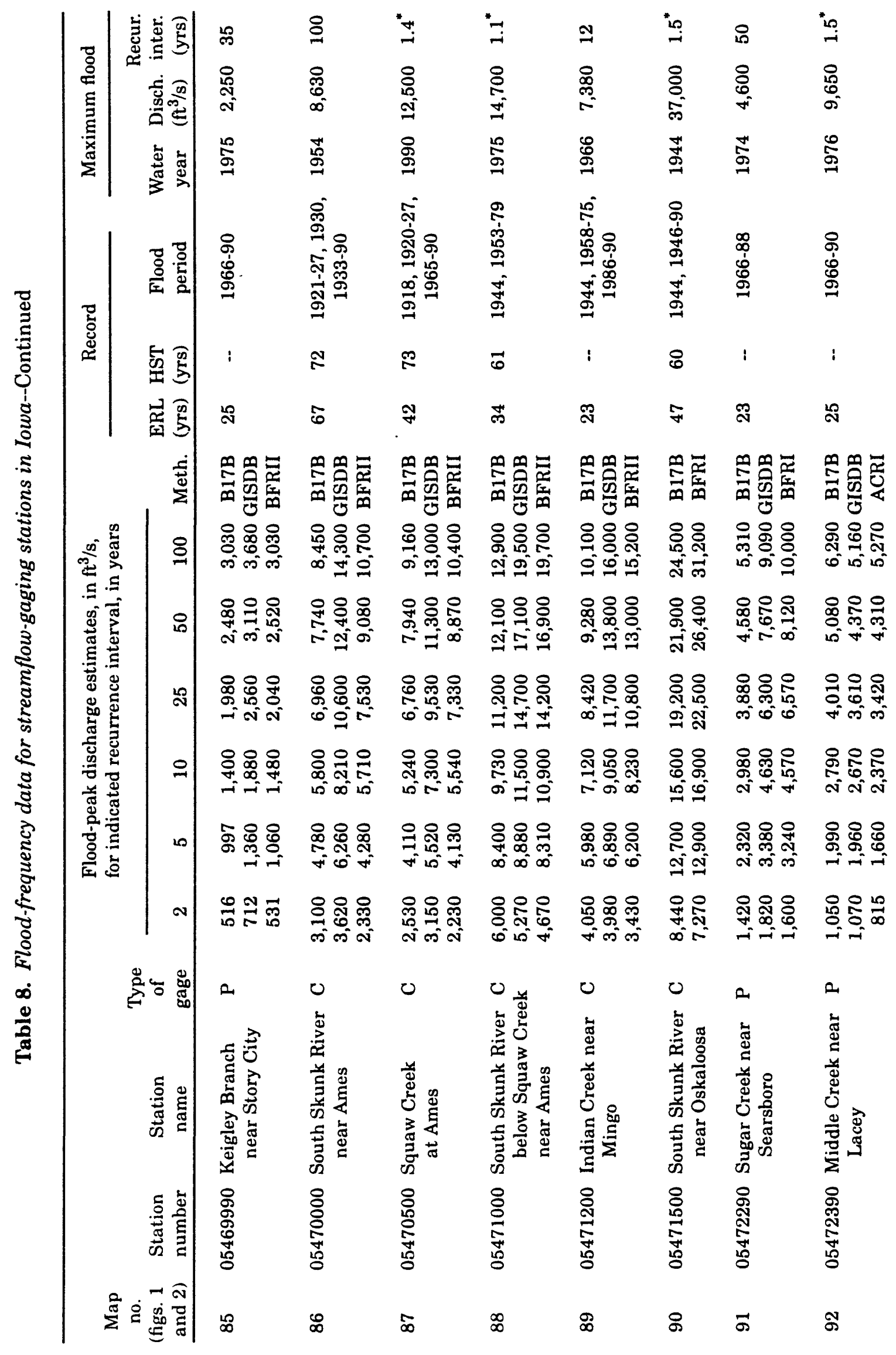




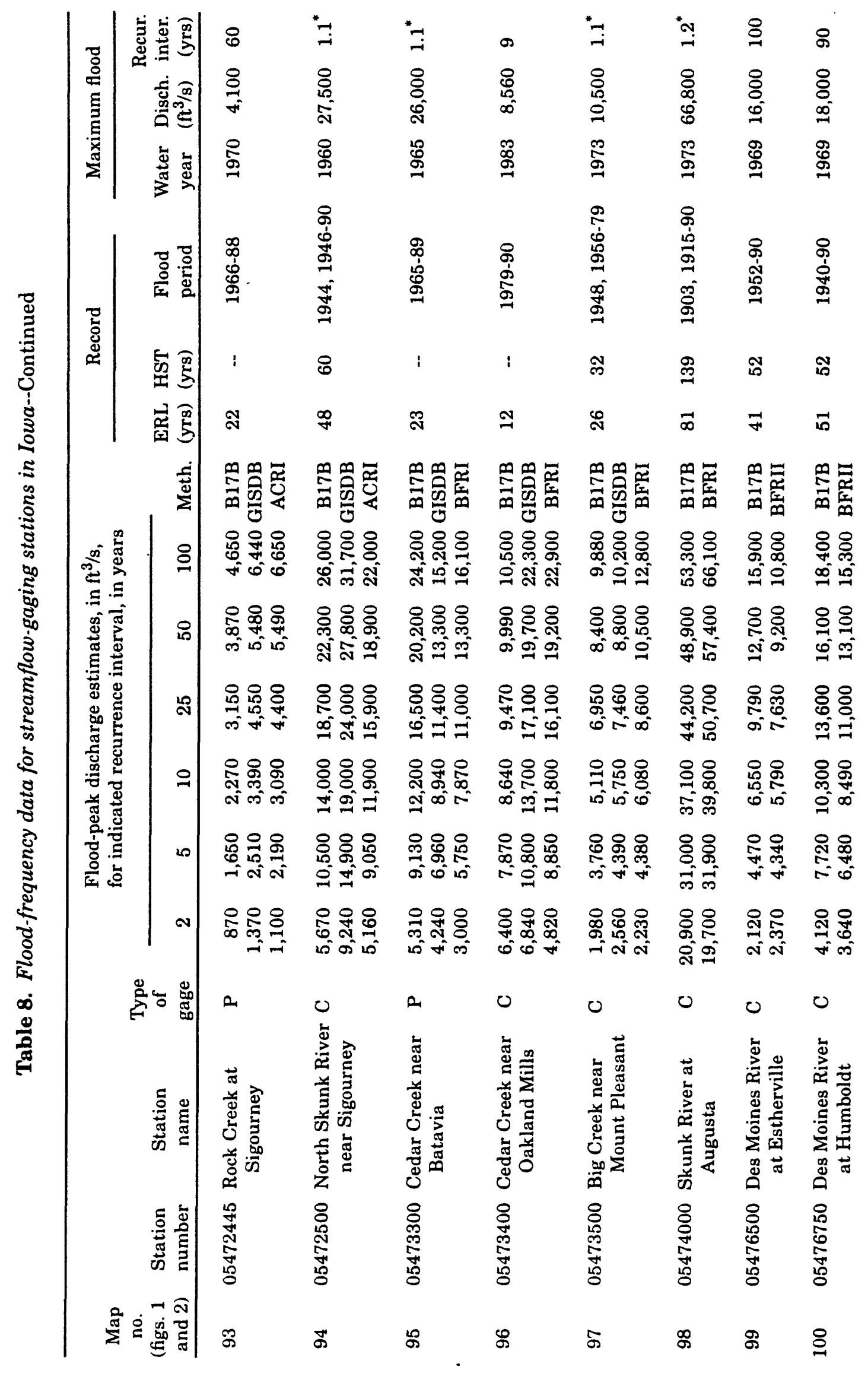




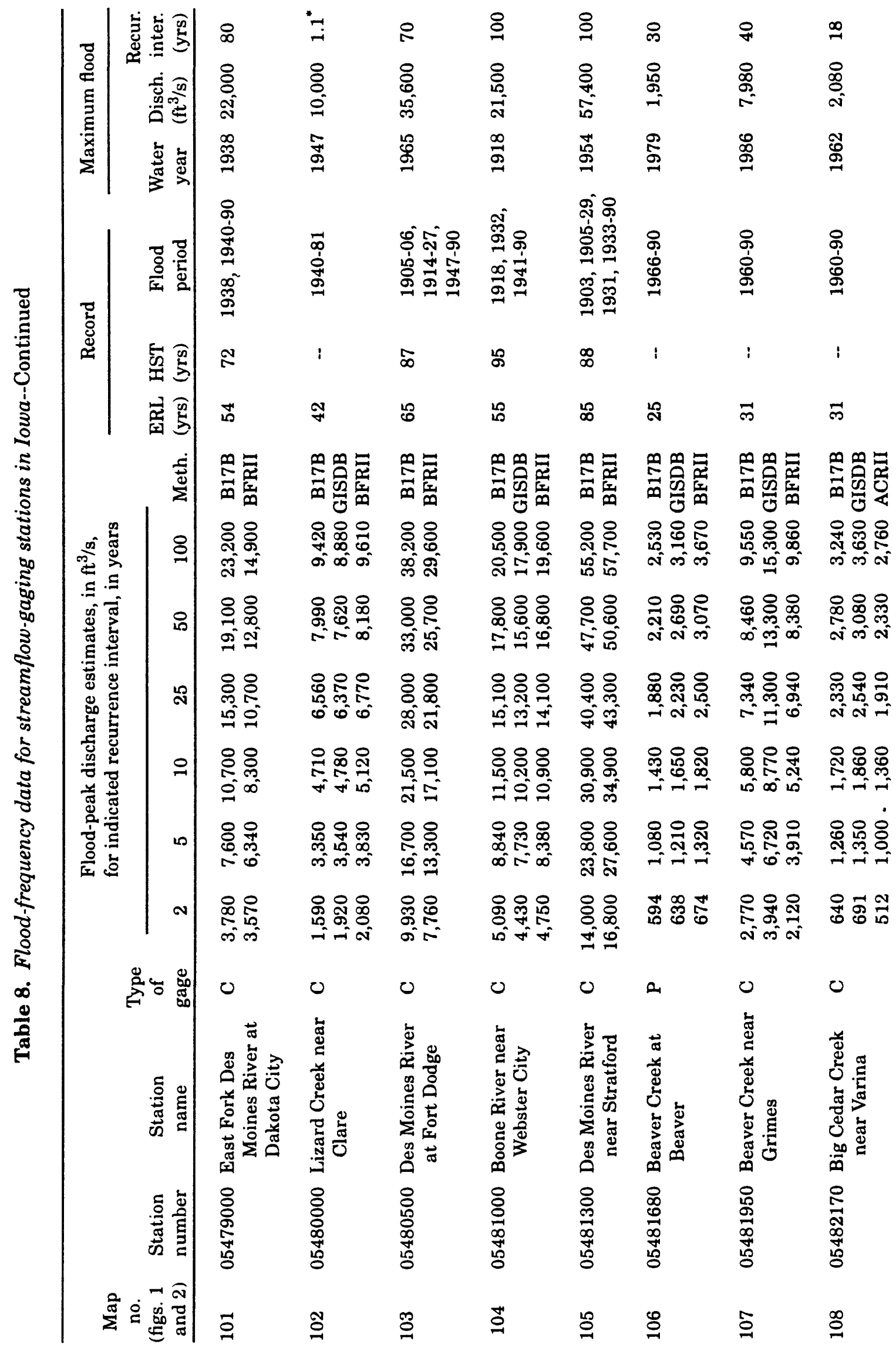




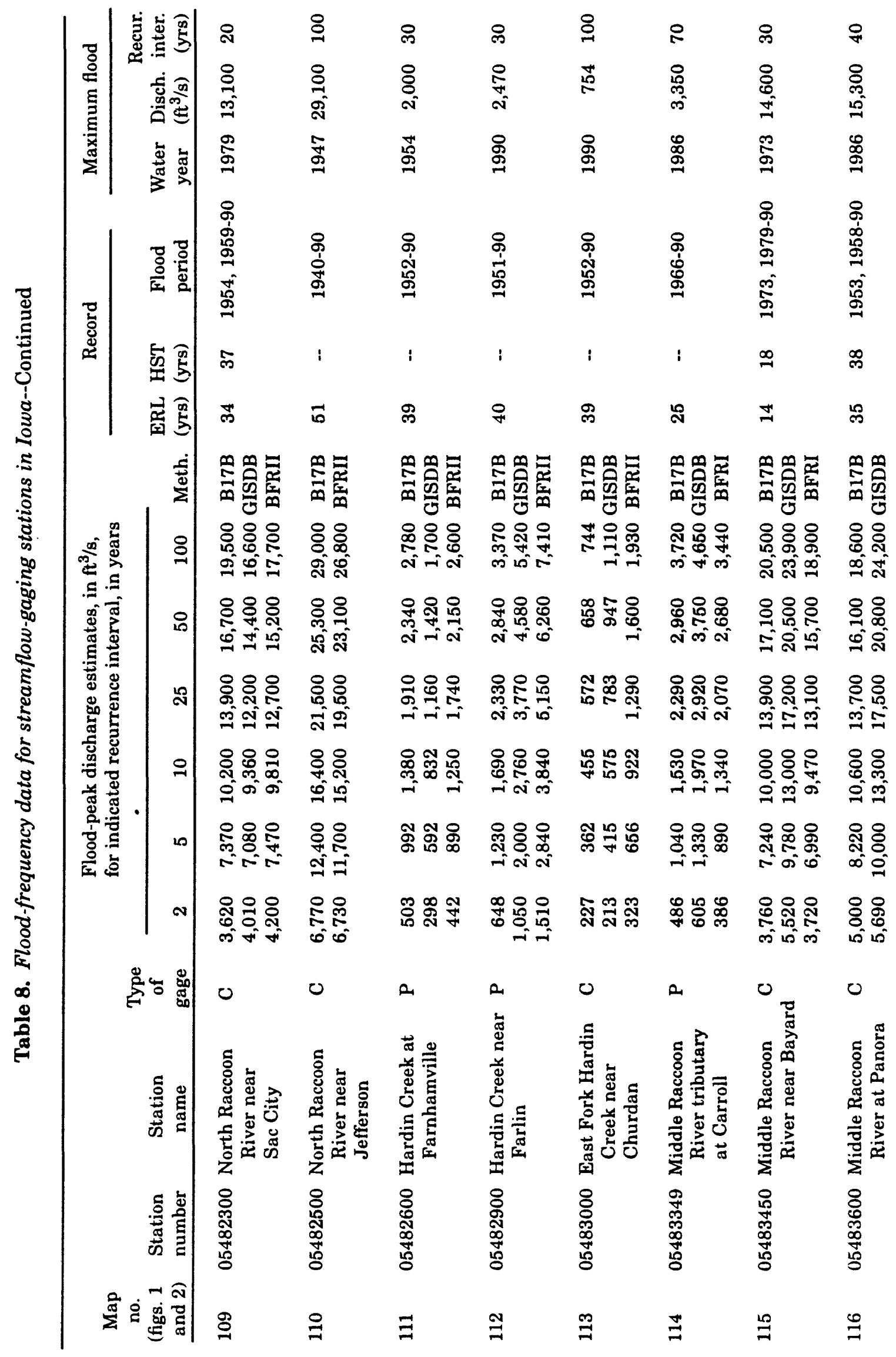




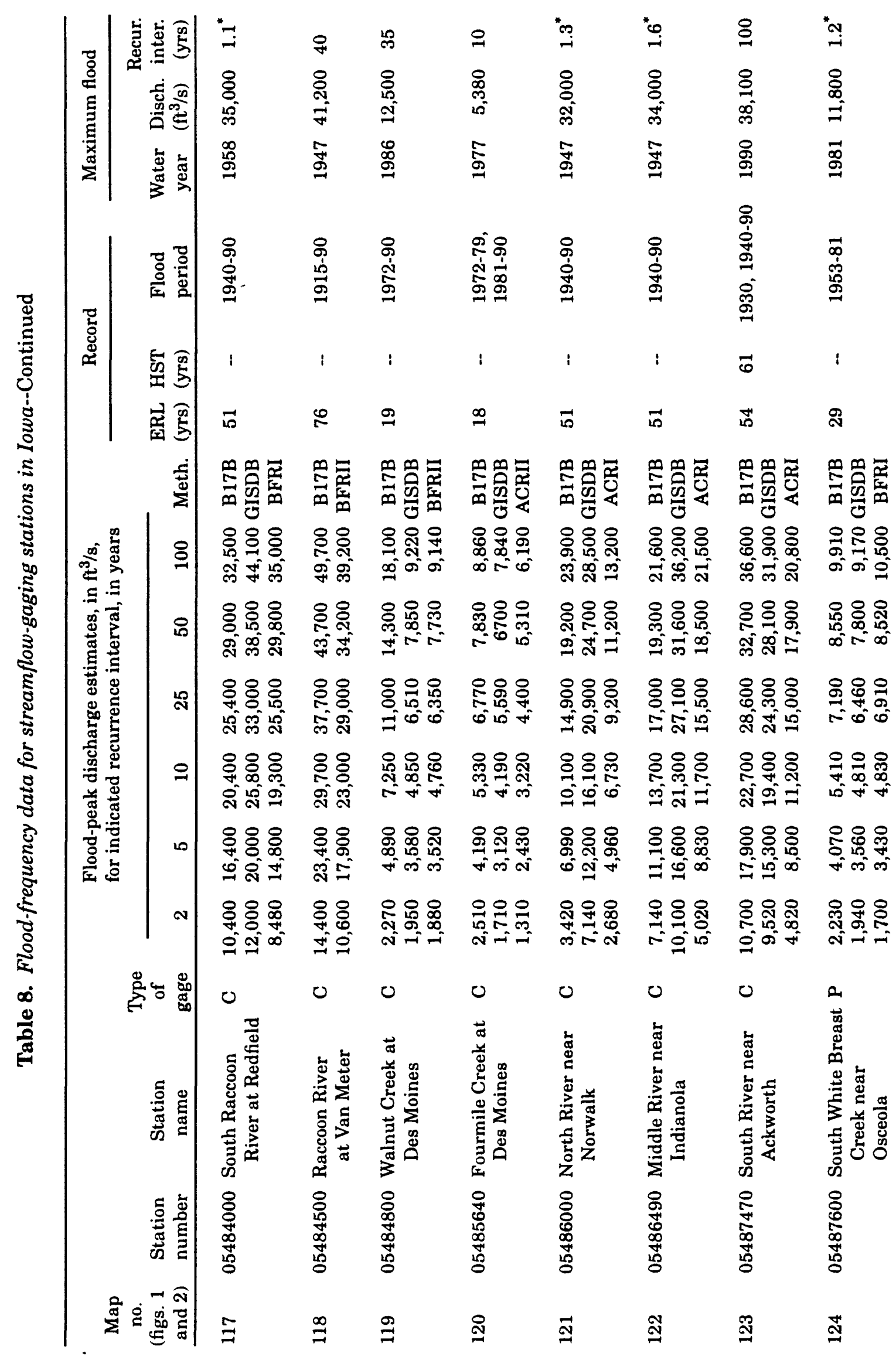




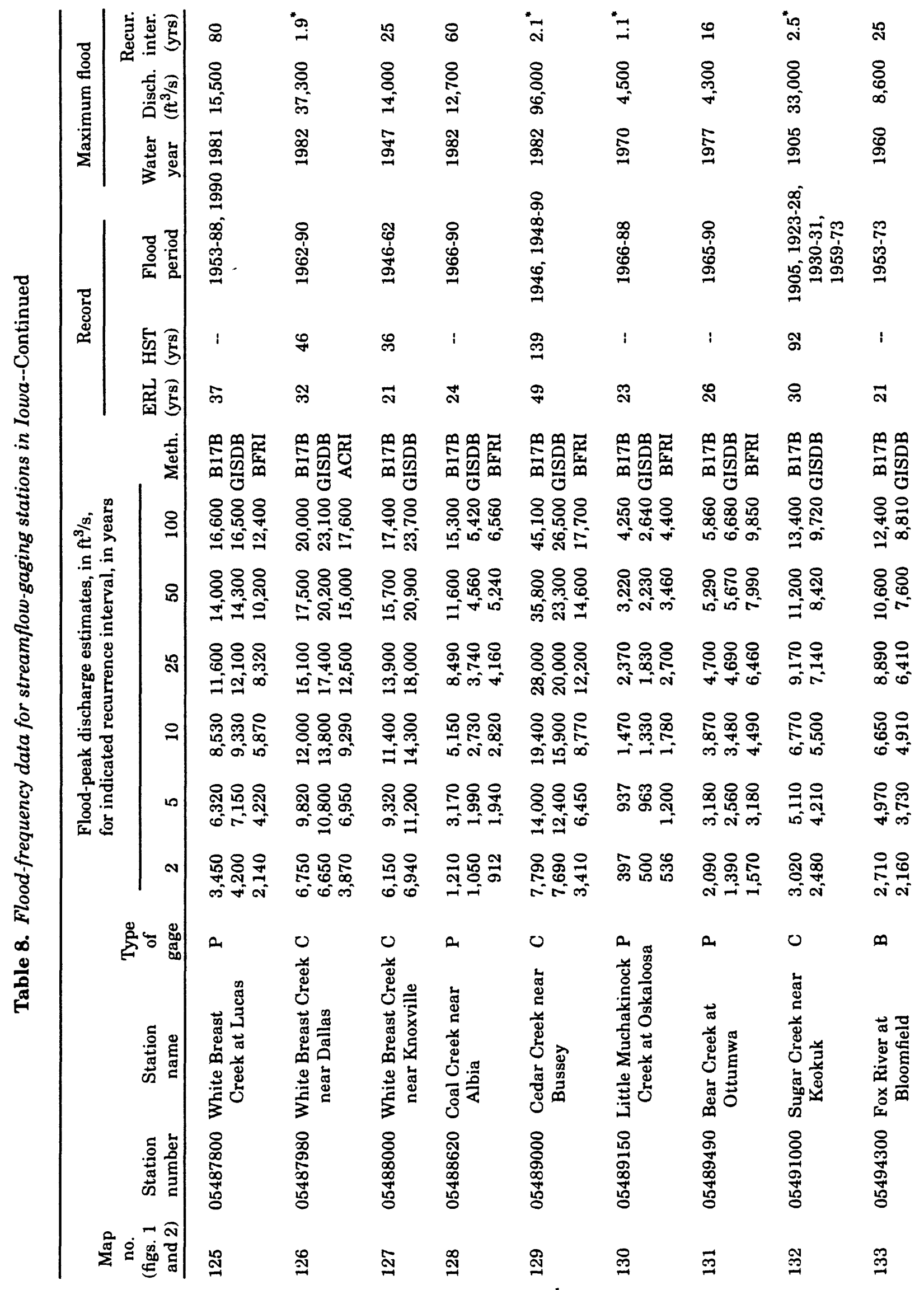




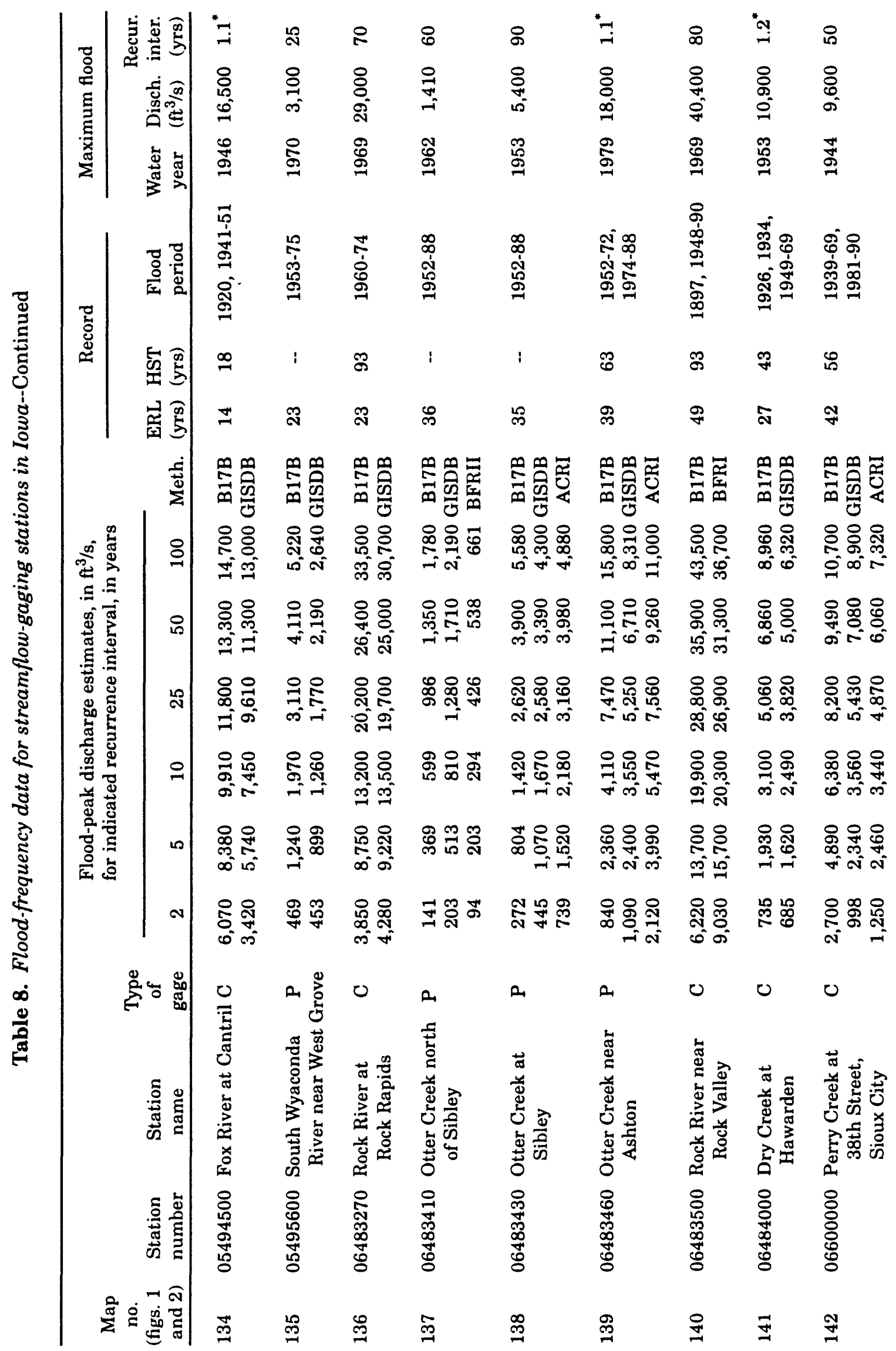




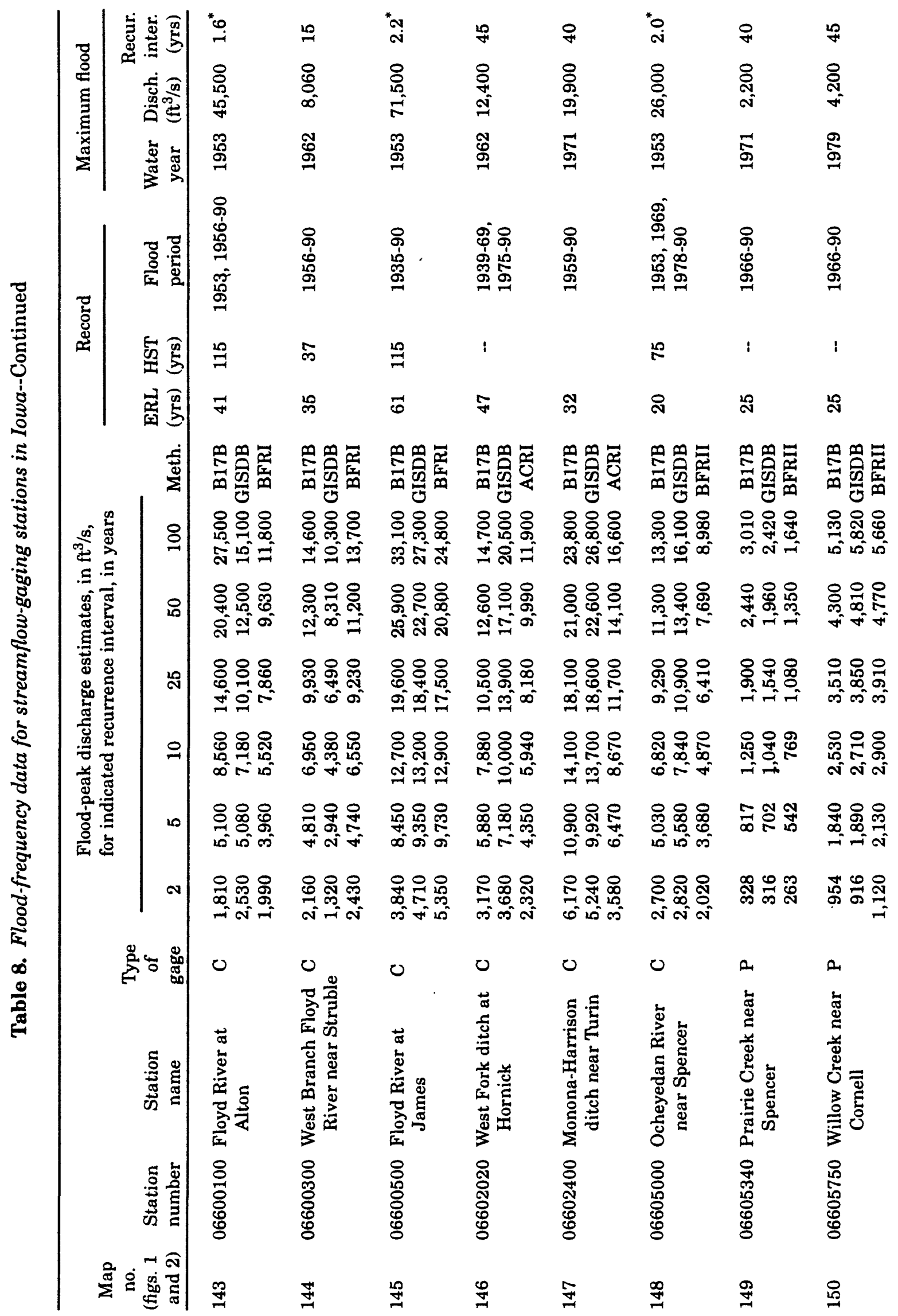




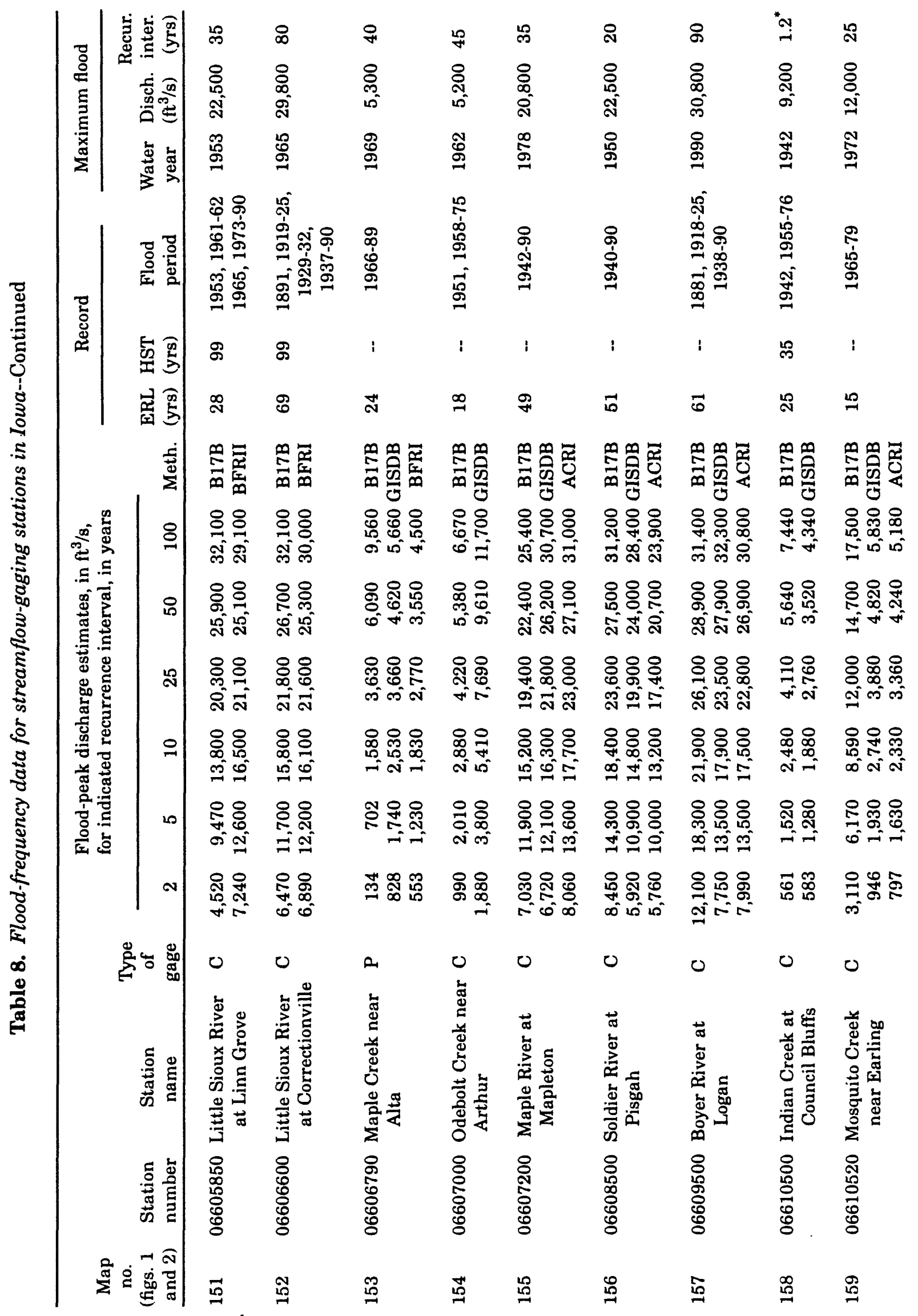




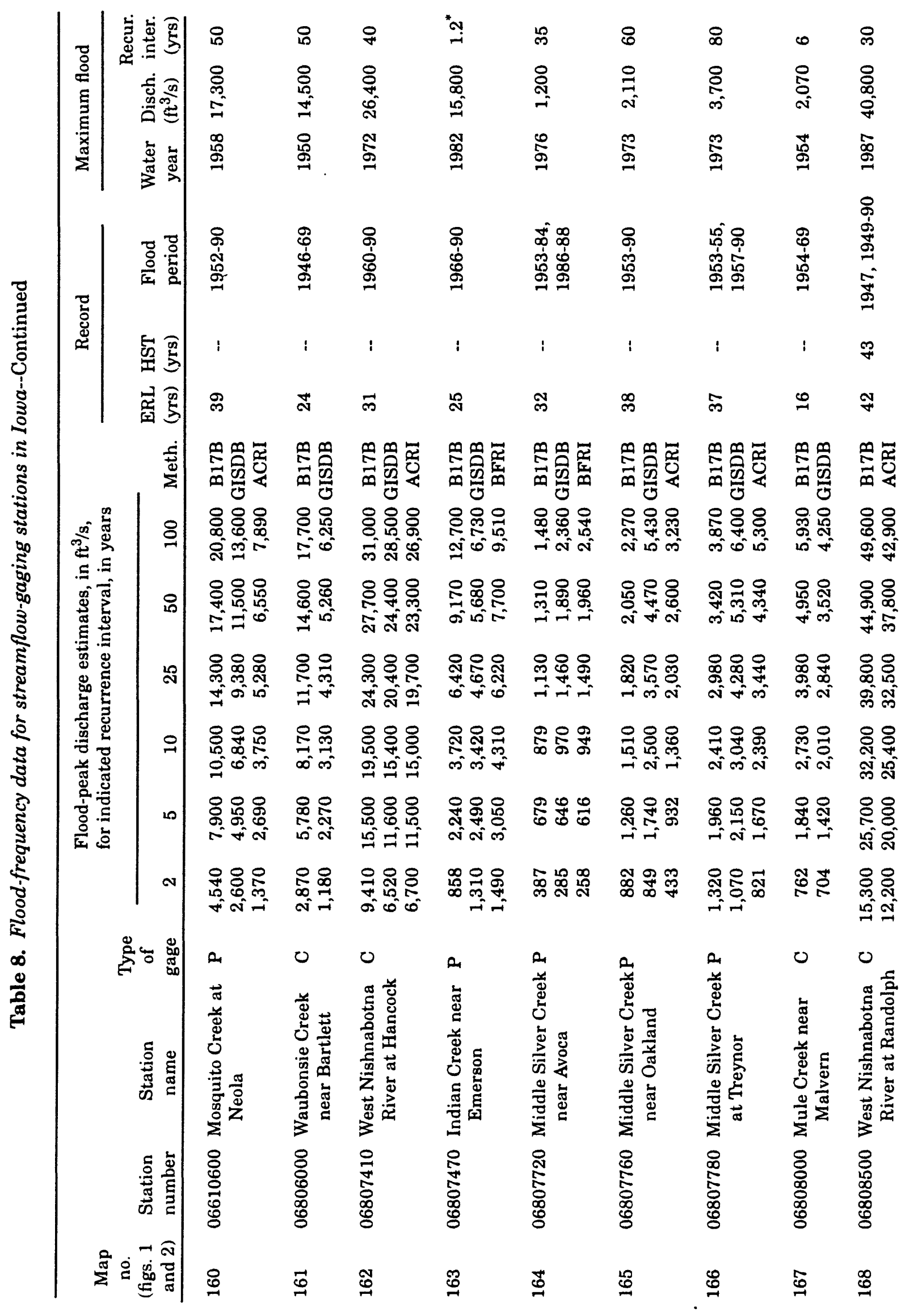




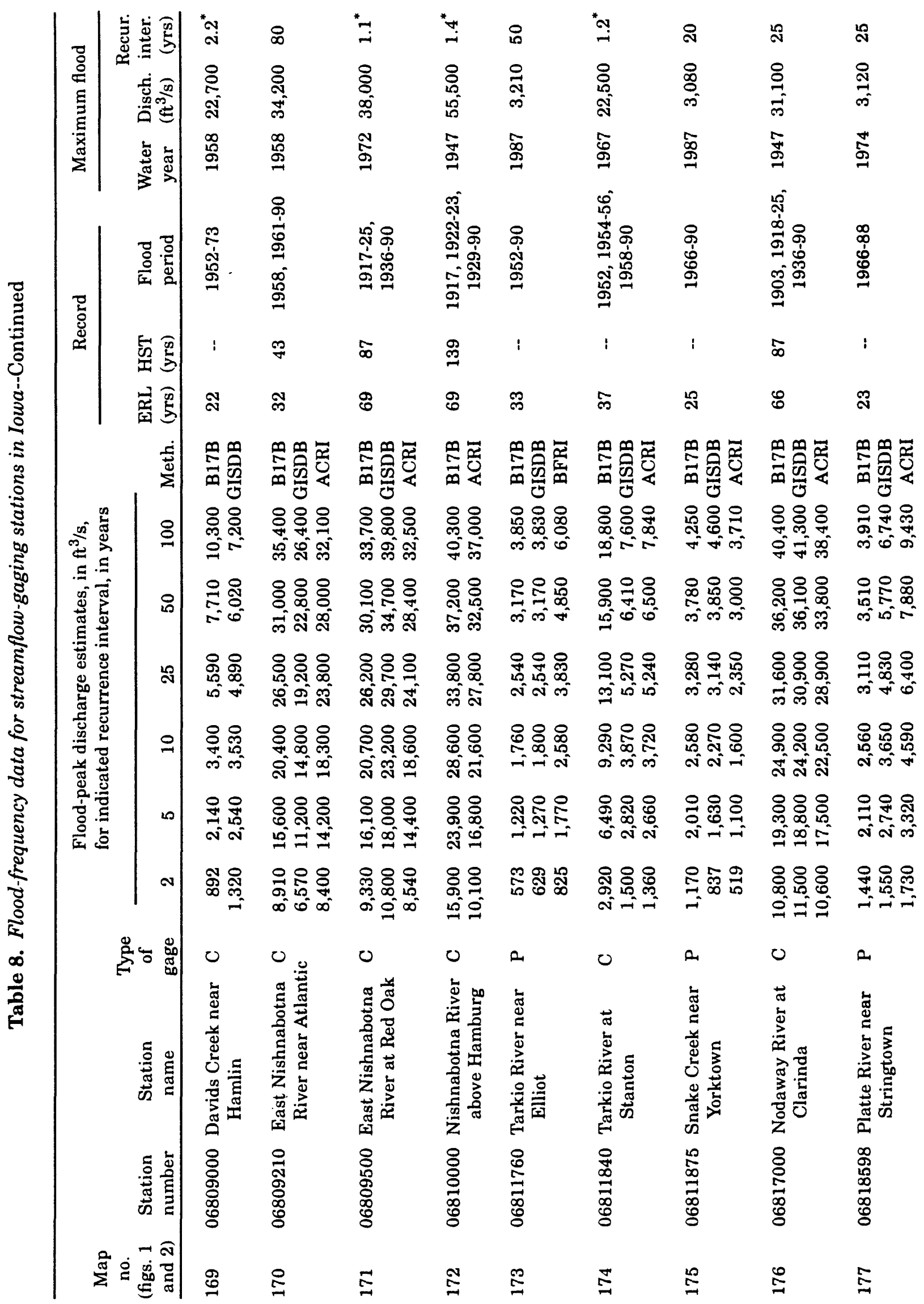




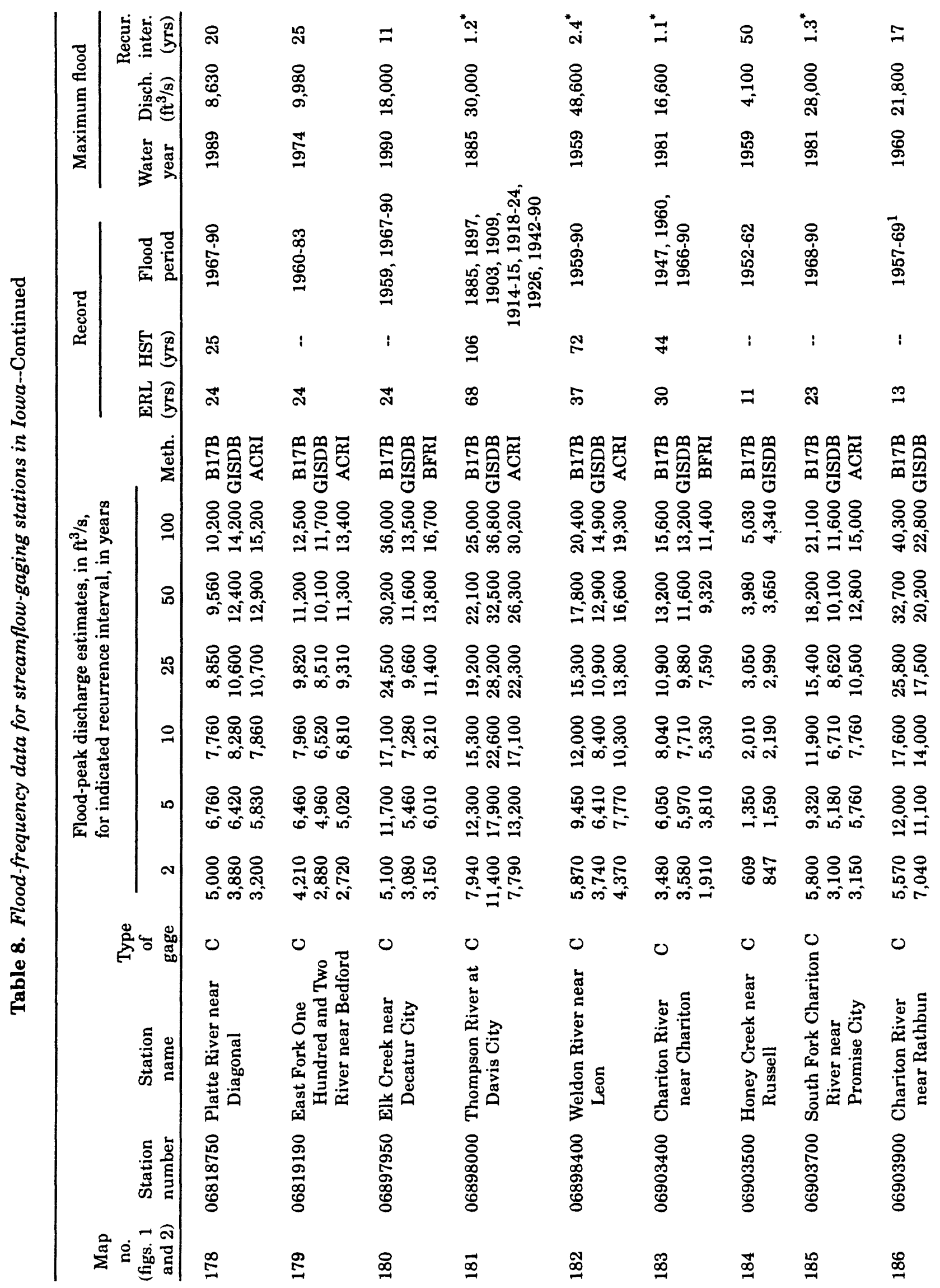




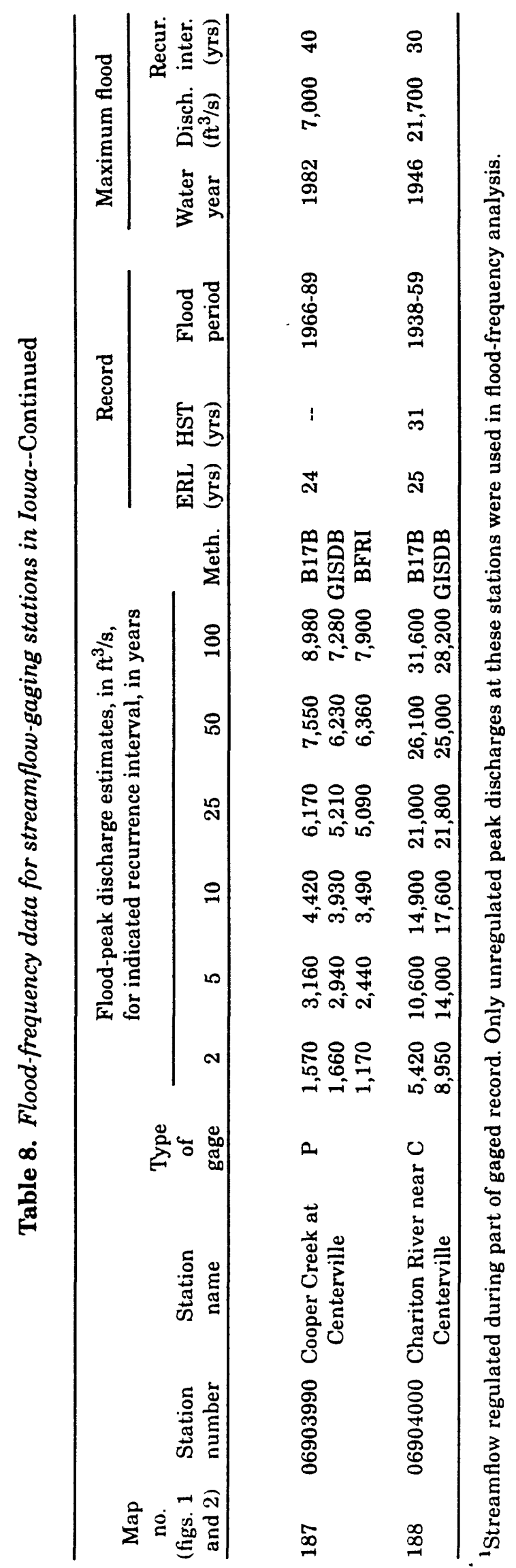




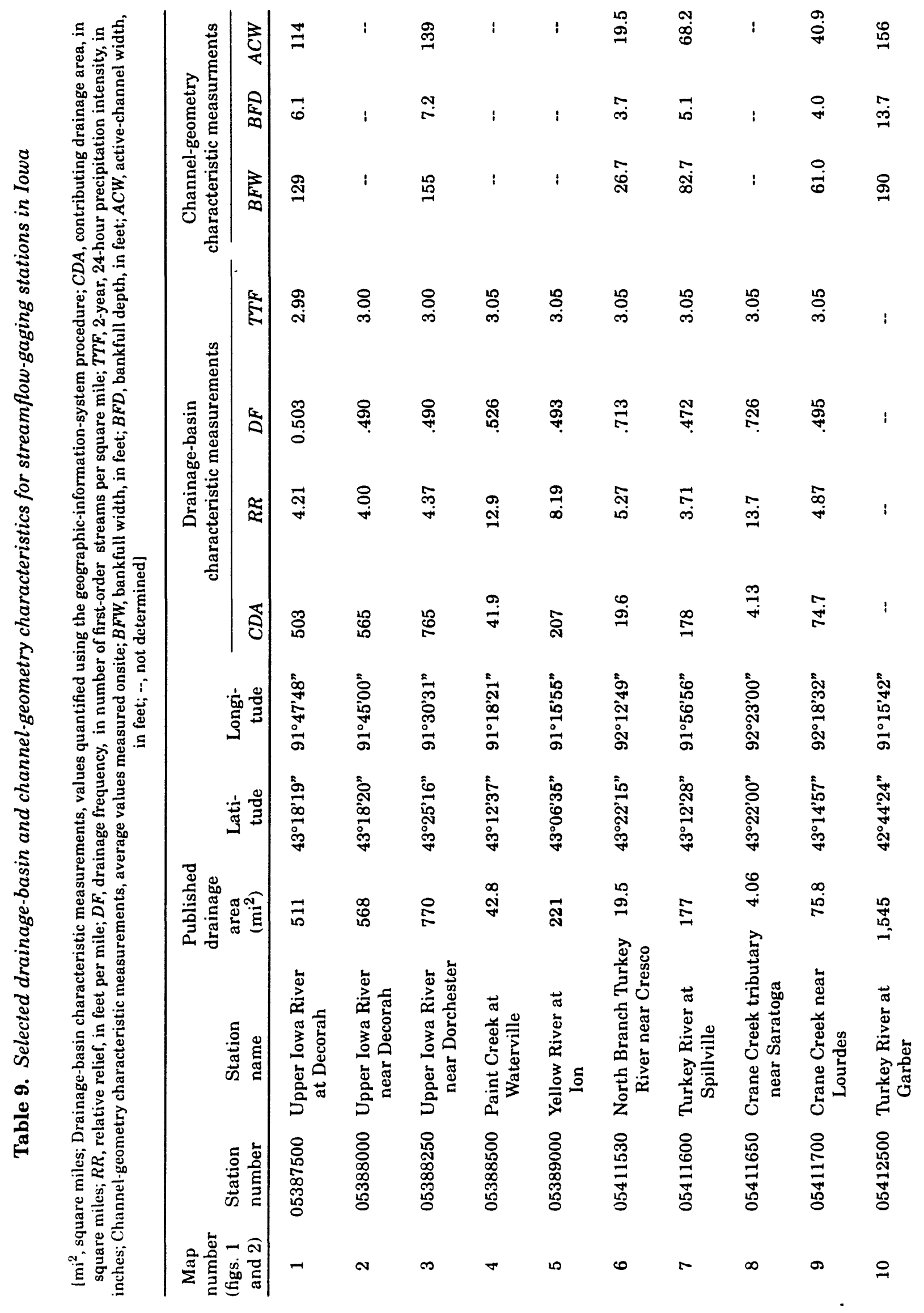




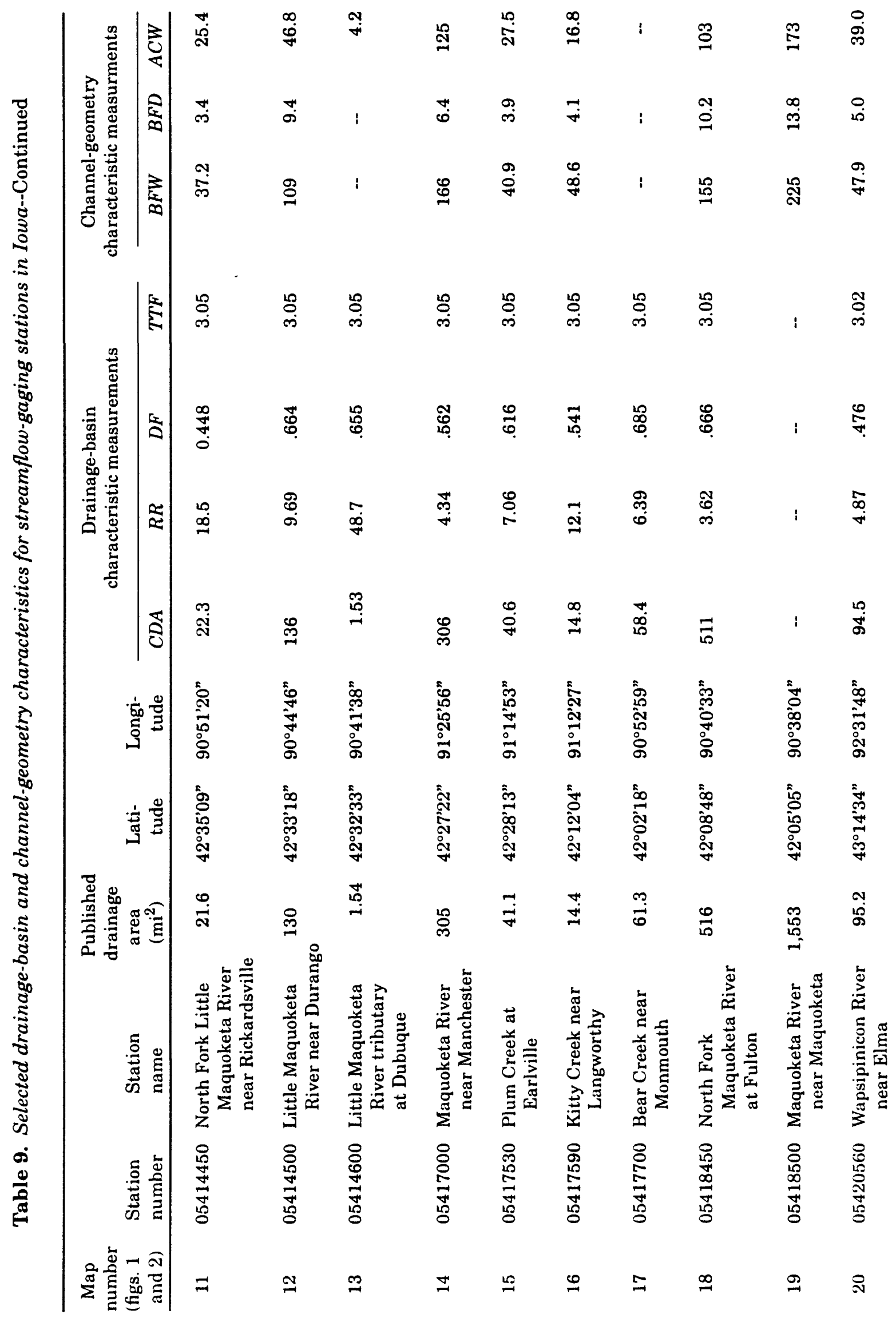




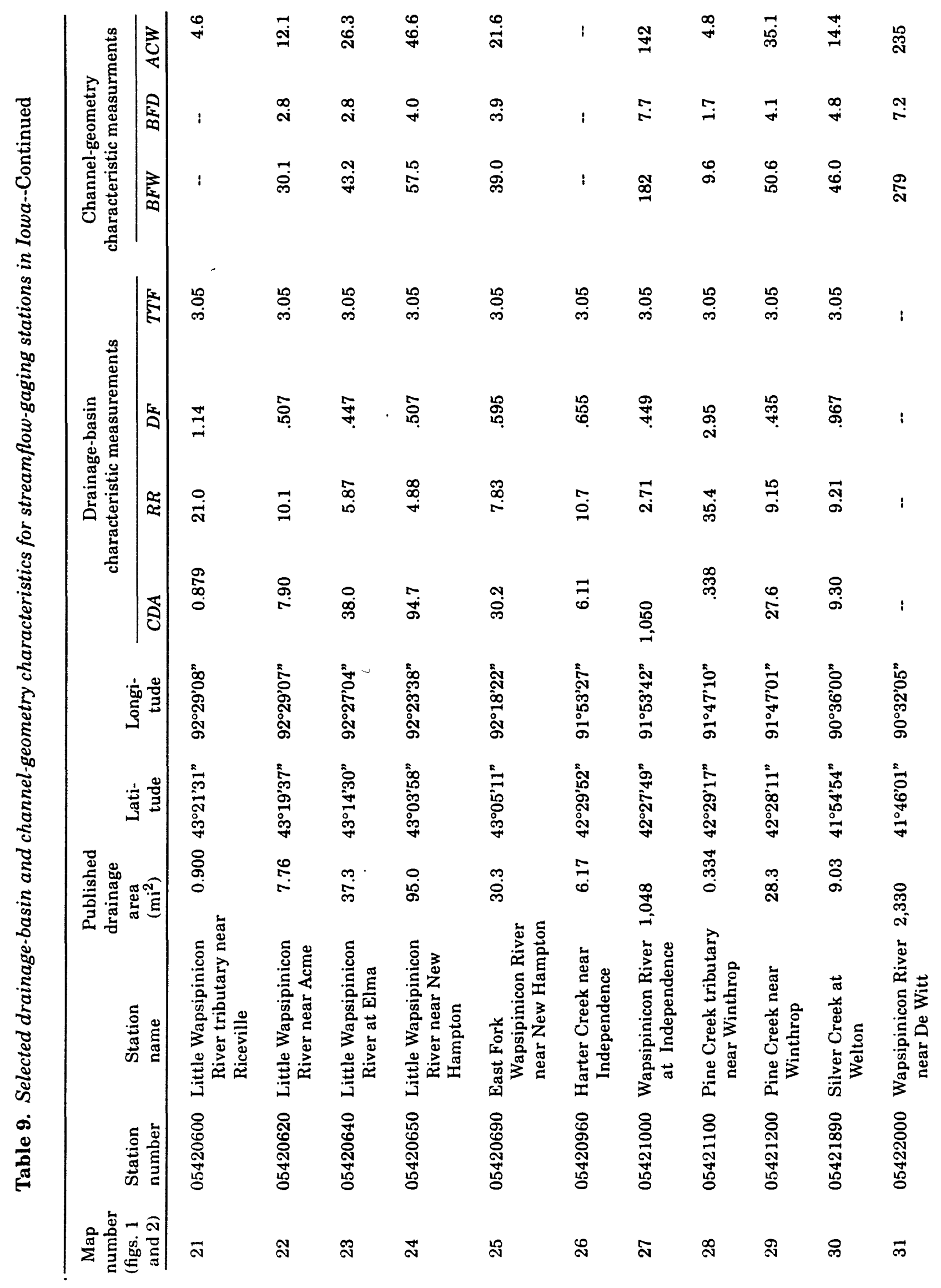




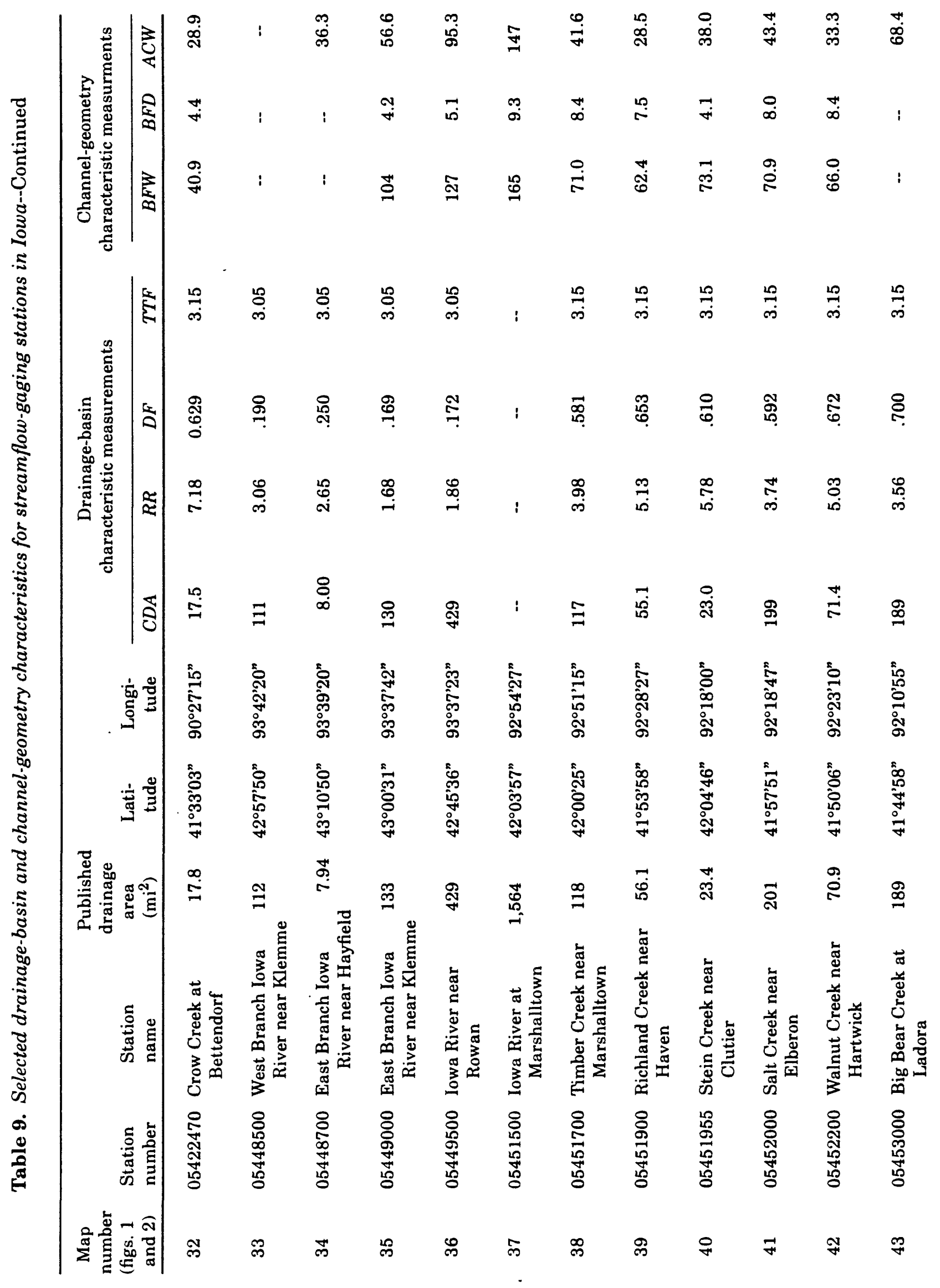




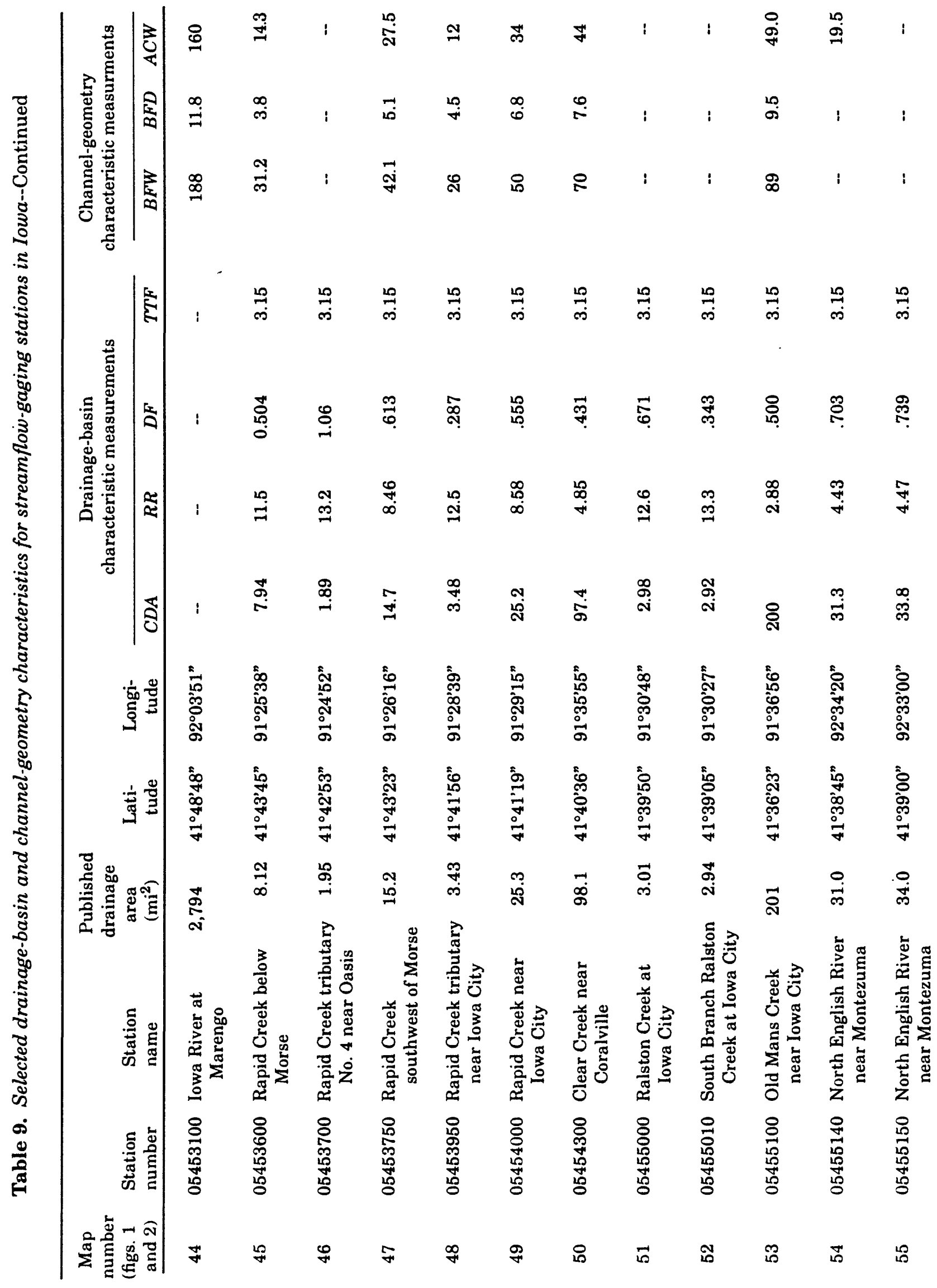




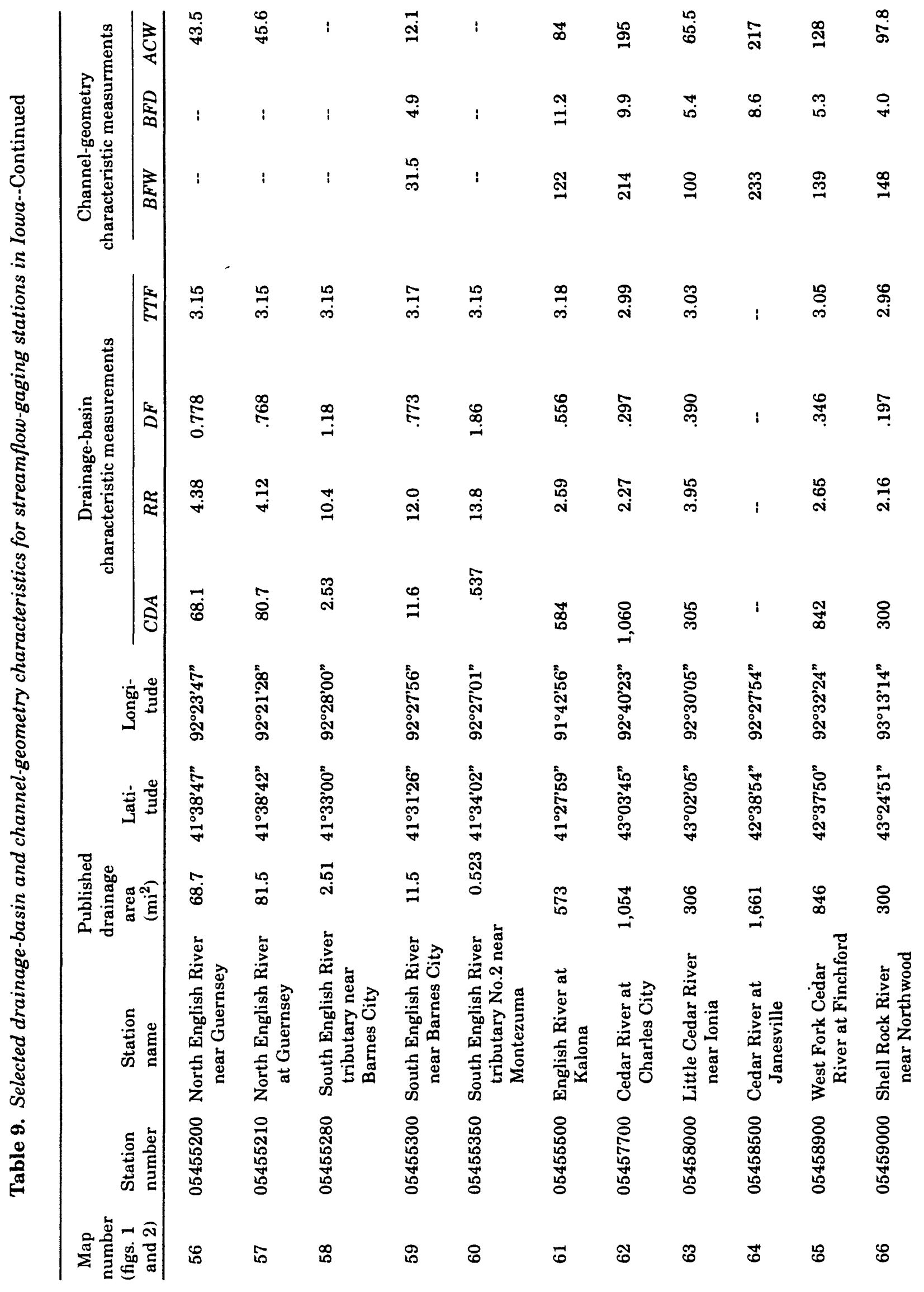




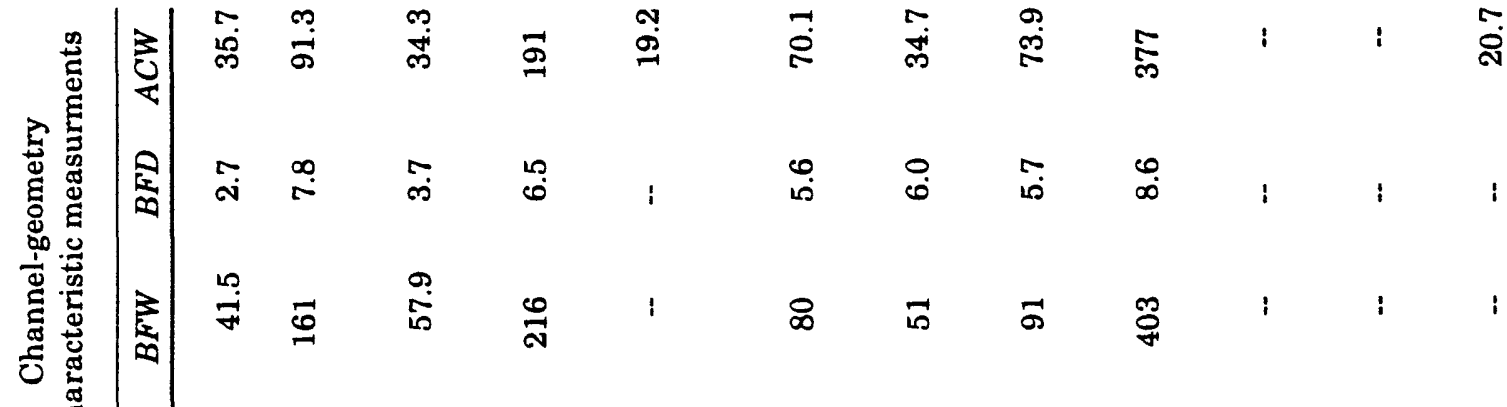

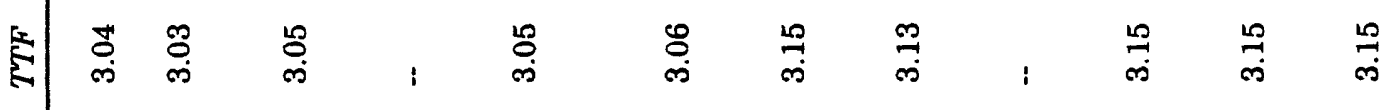

结

竞管

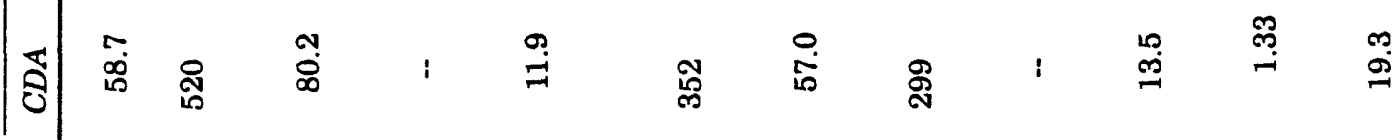

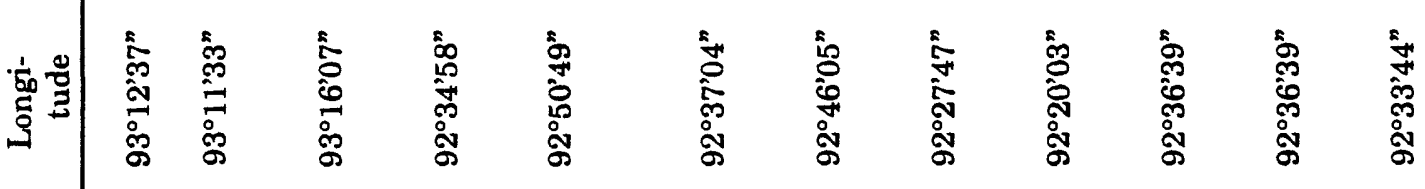

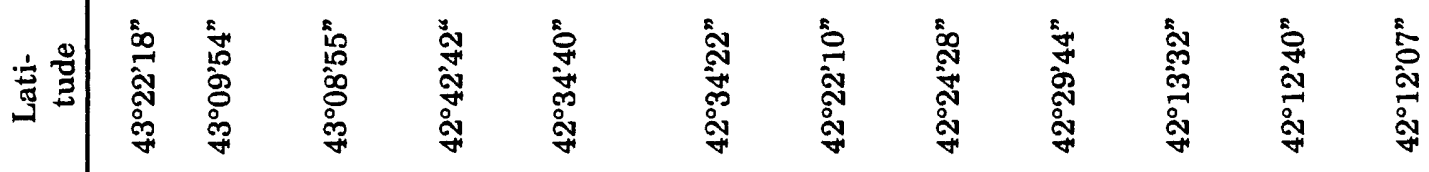

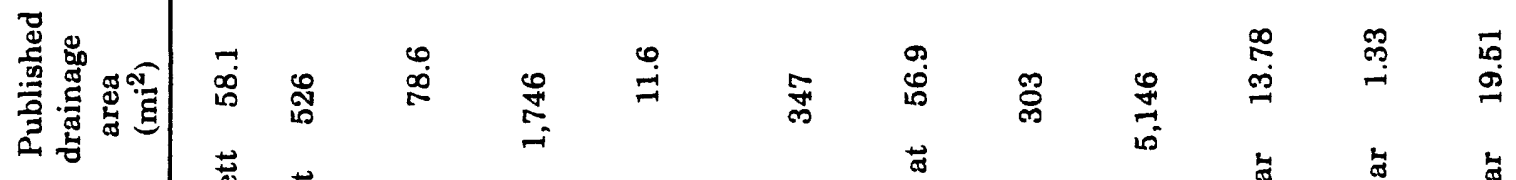

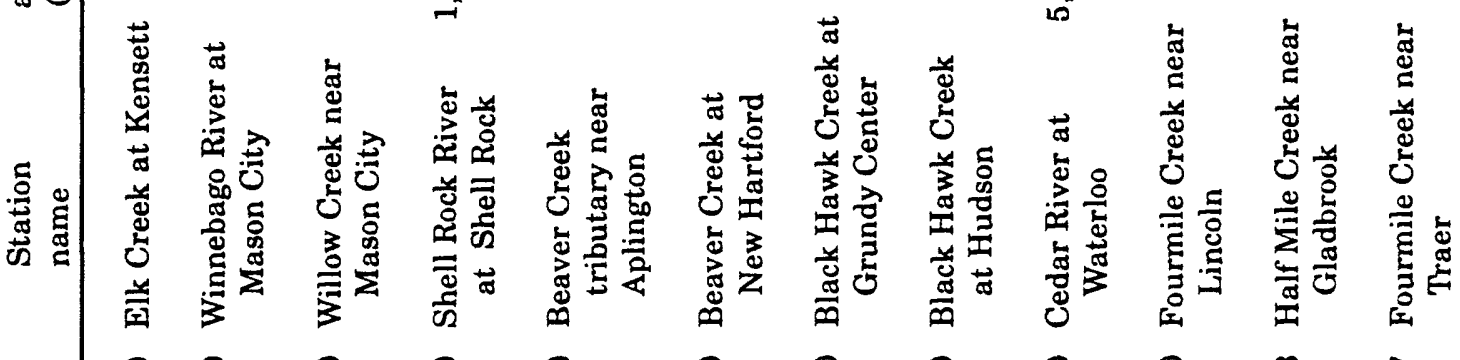

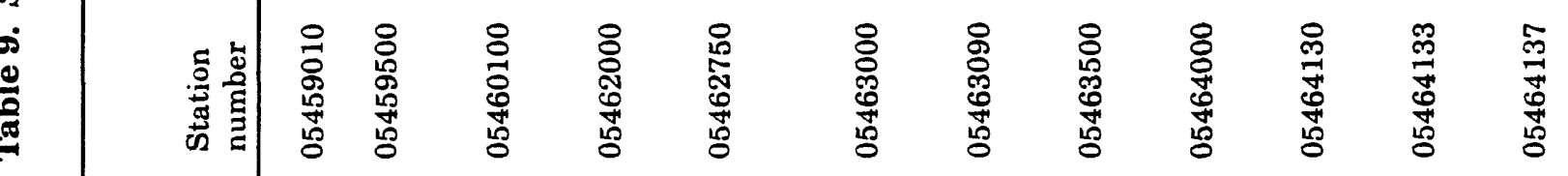

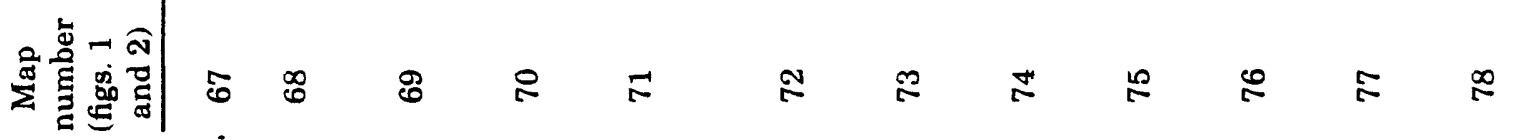




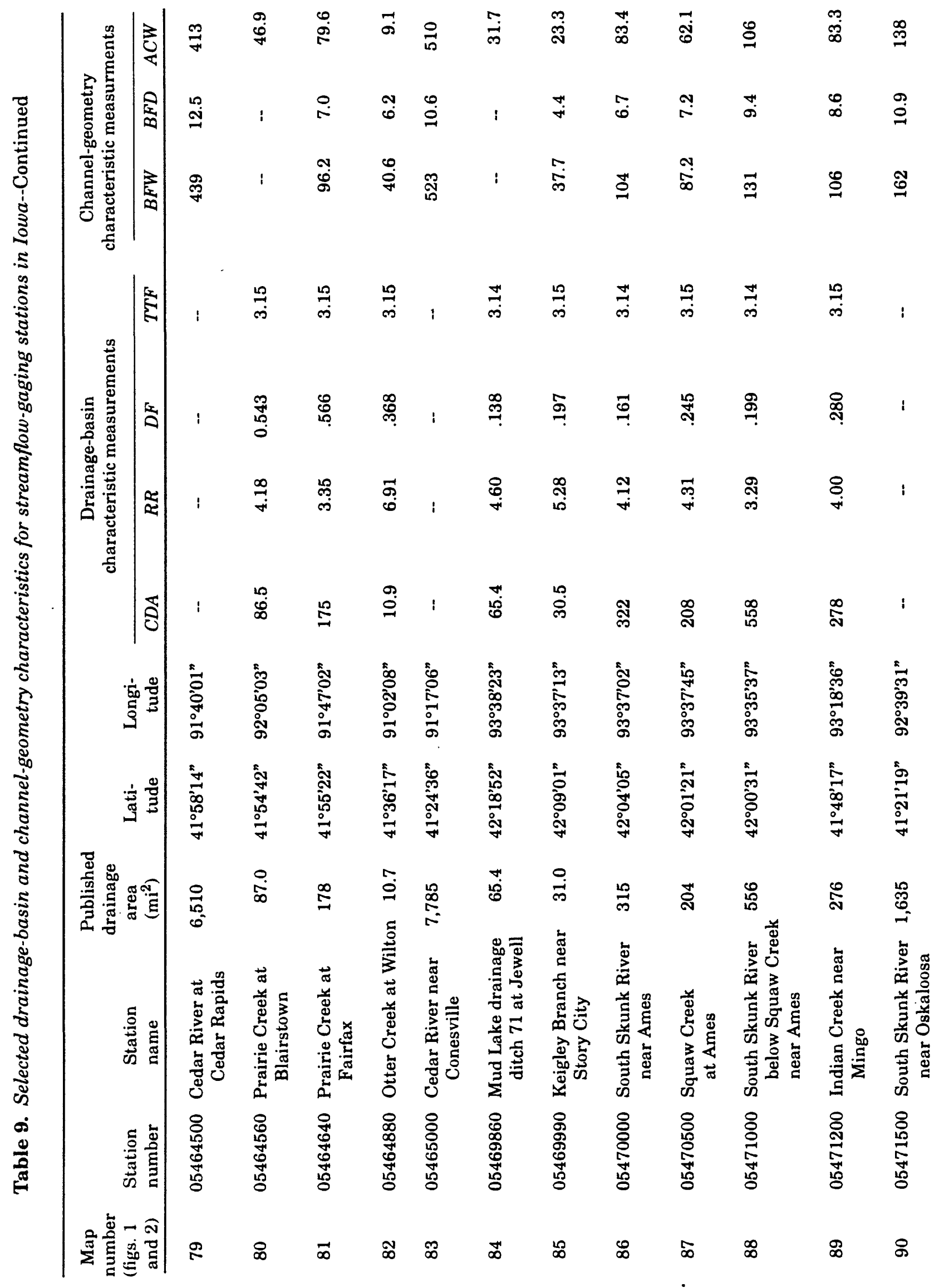




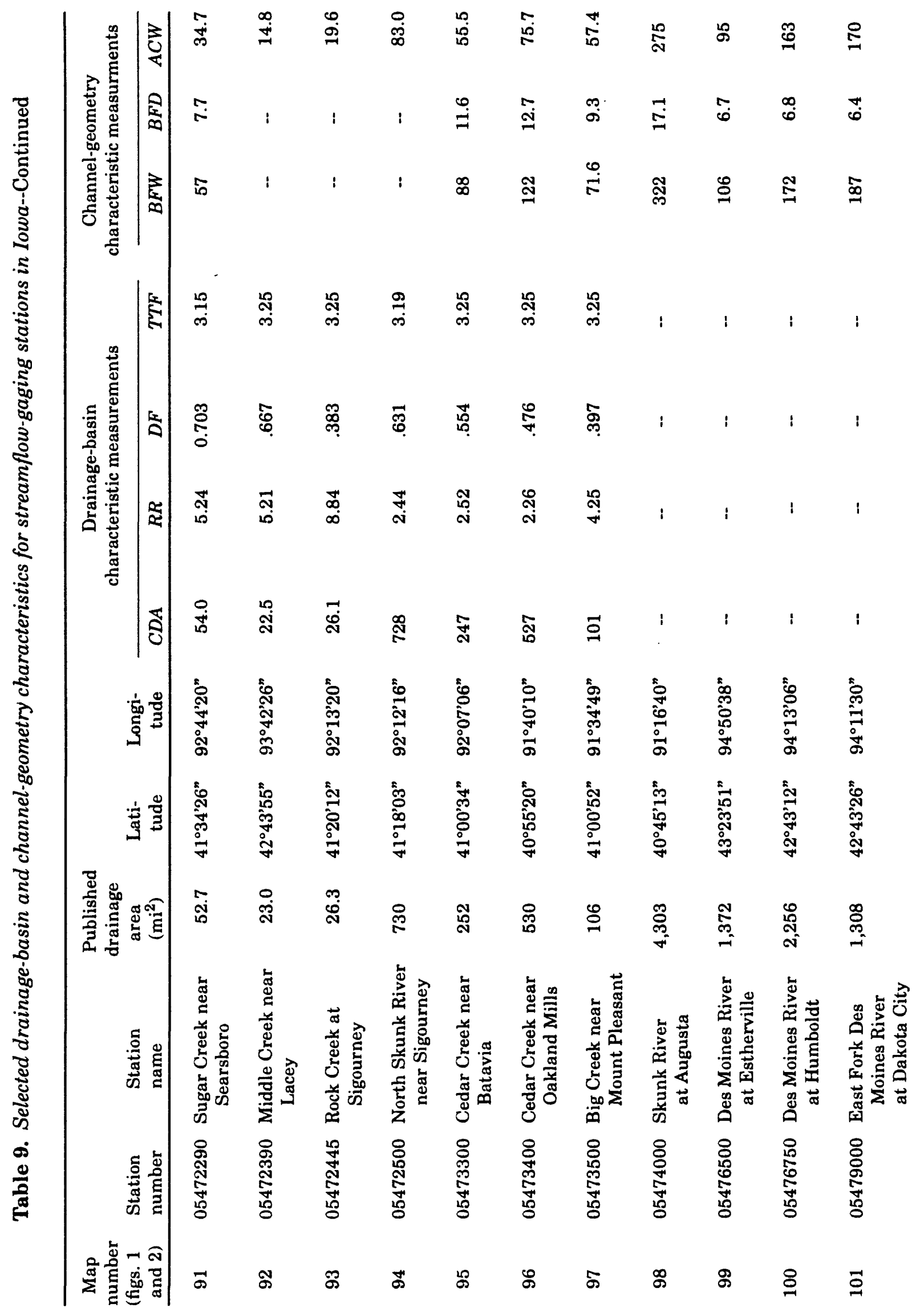




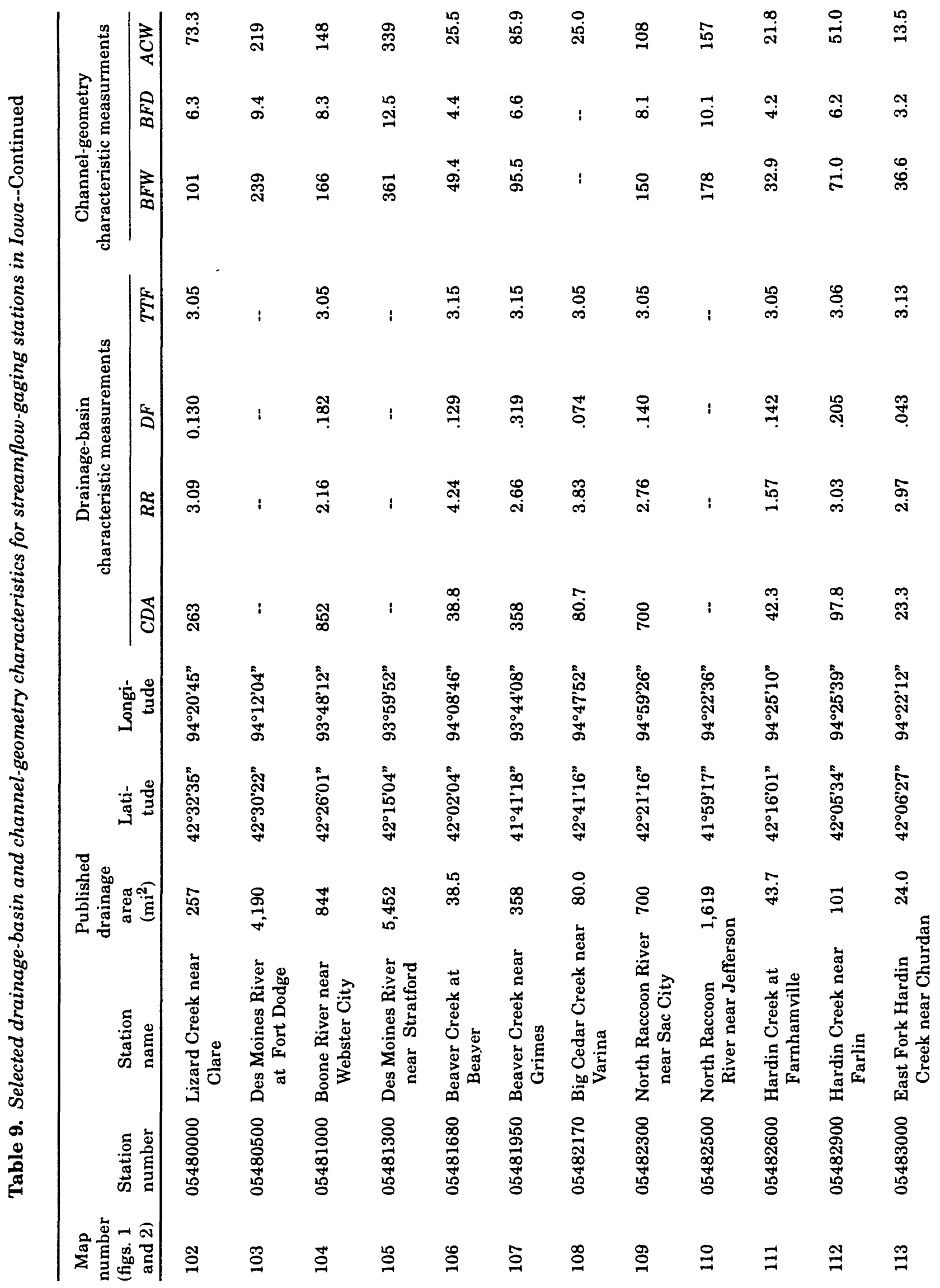




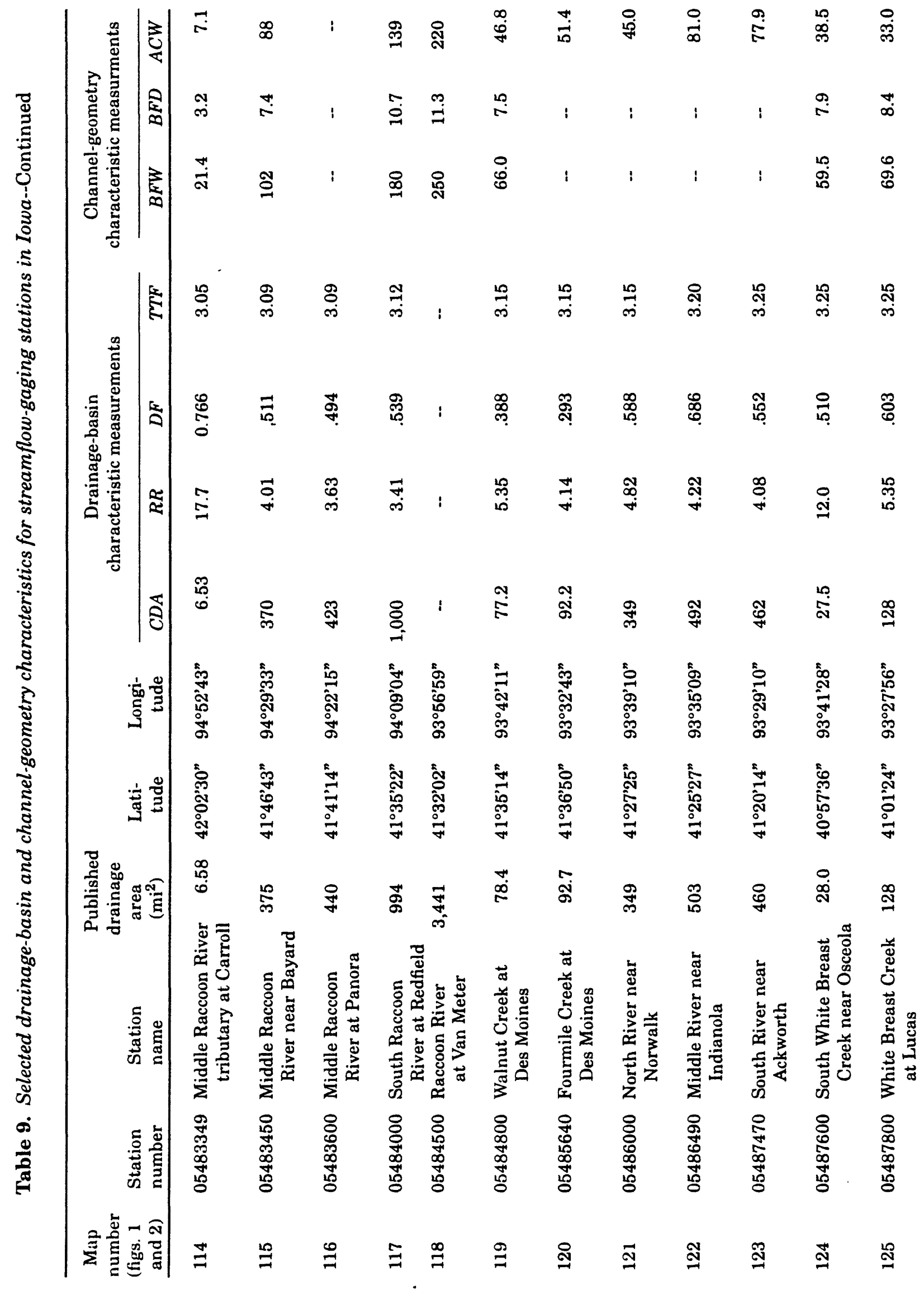




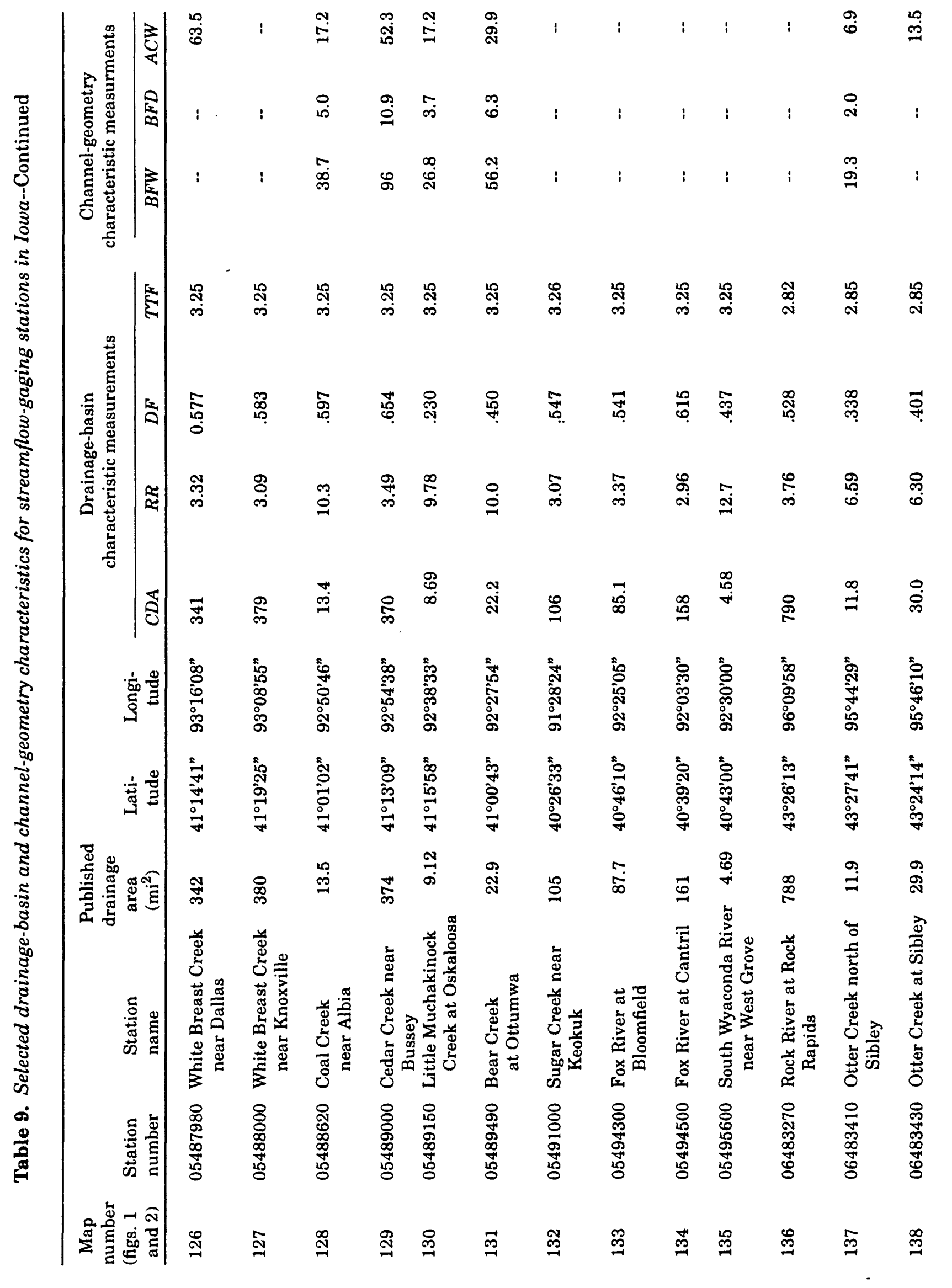




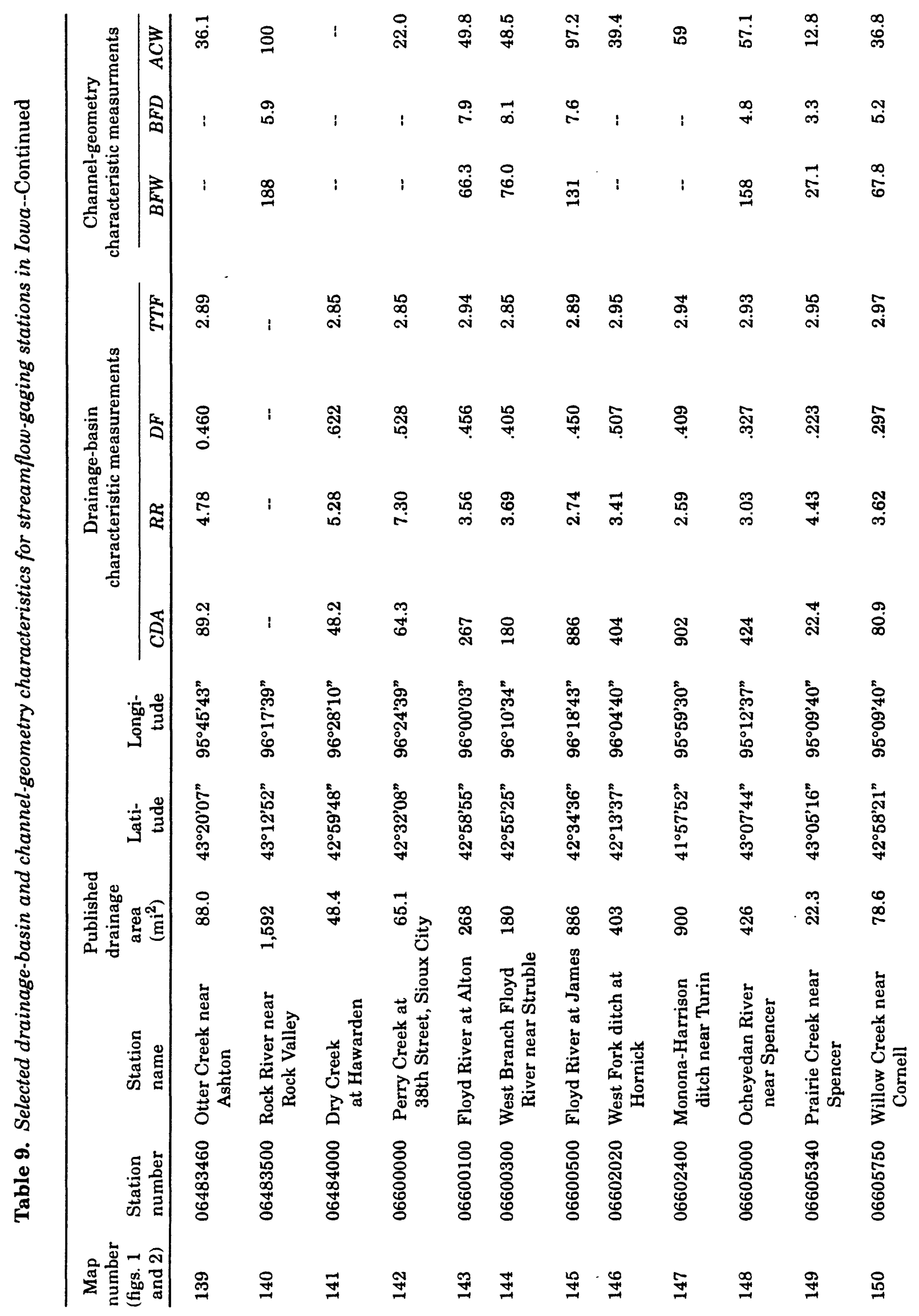




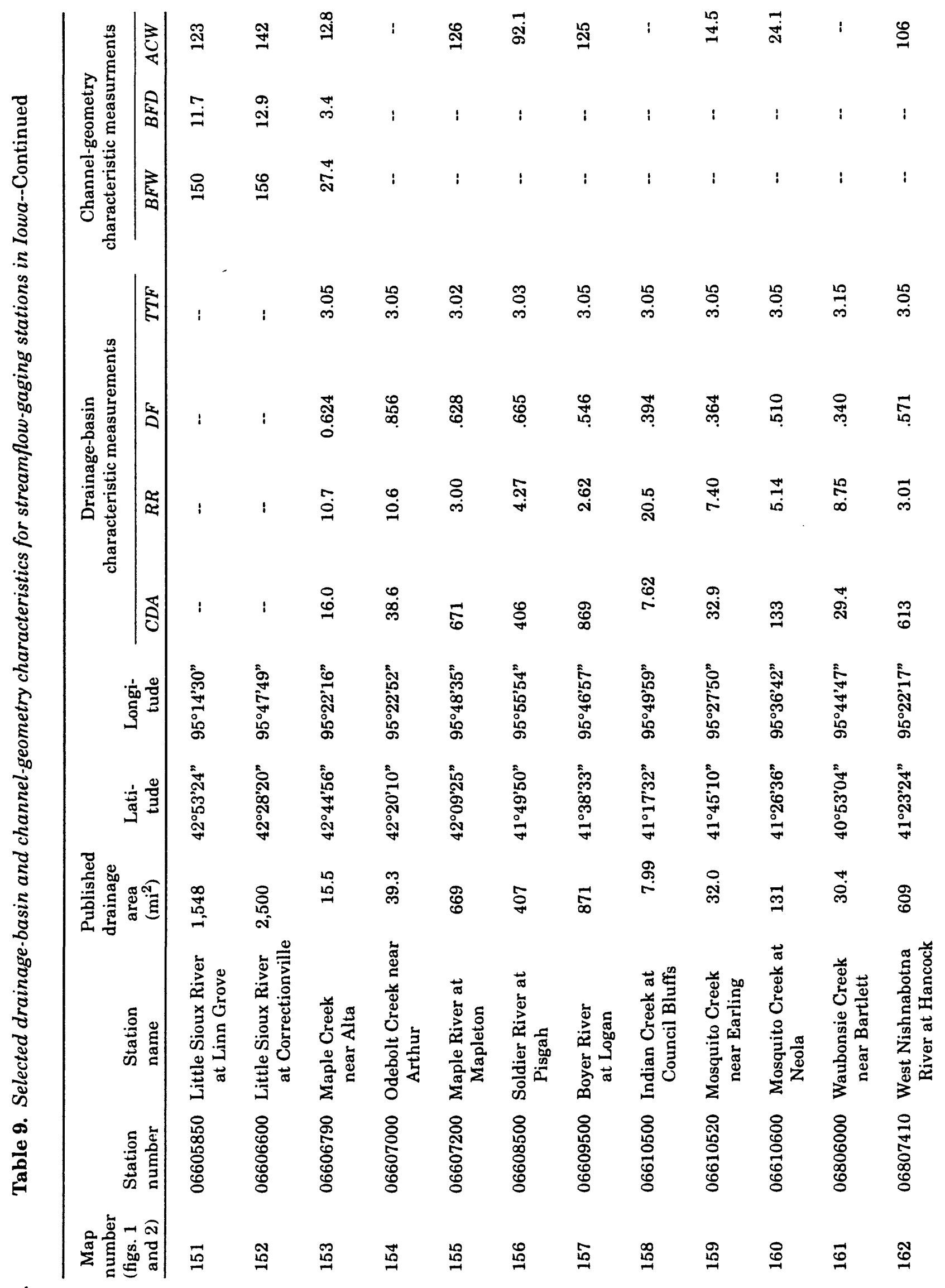




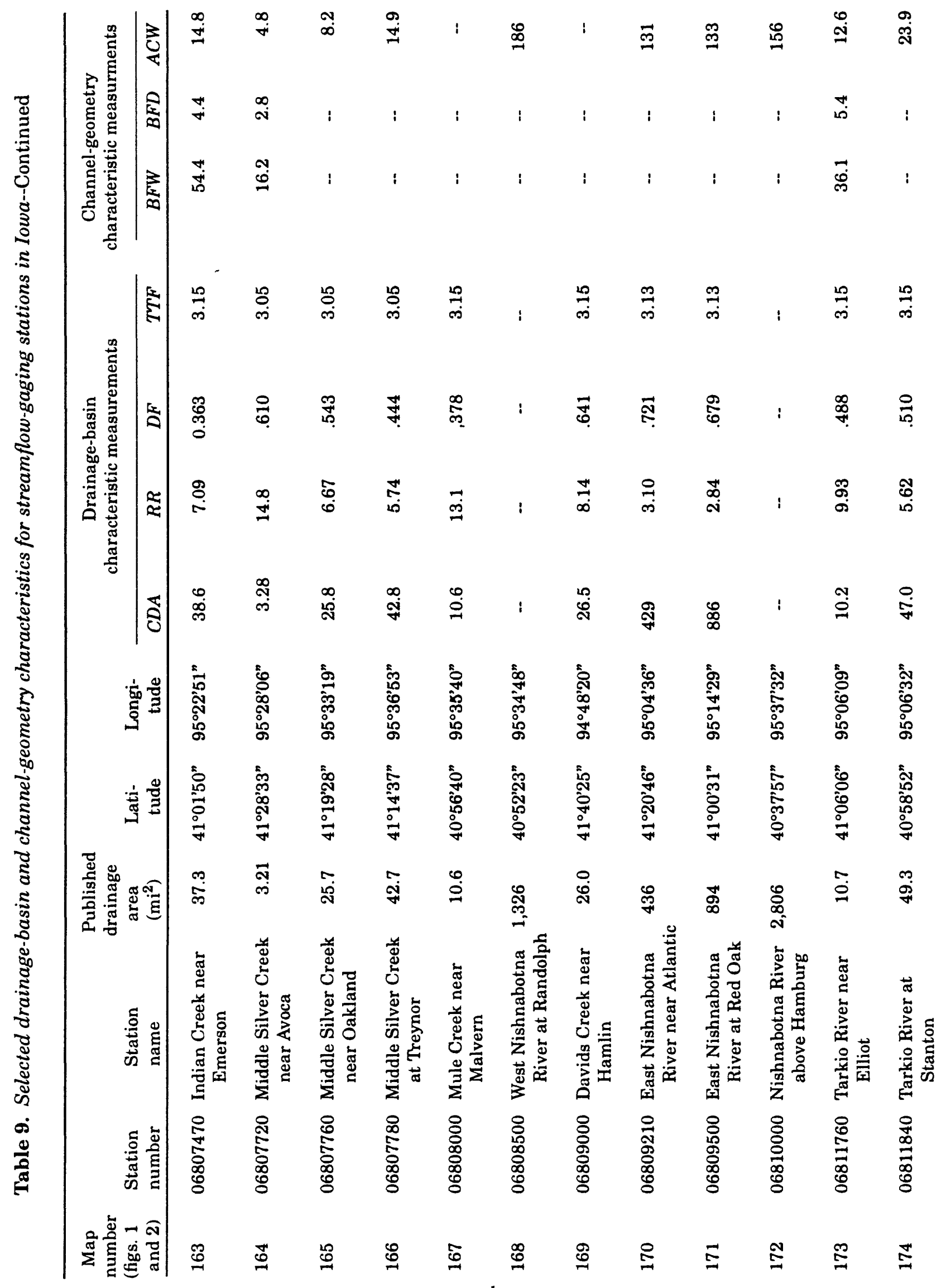




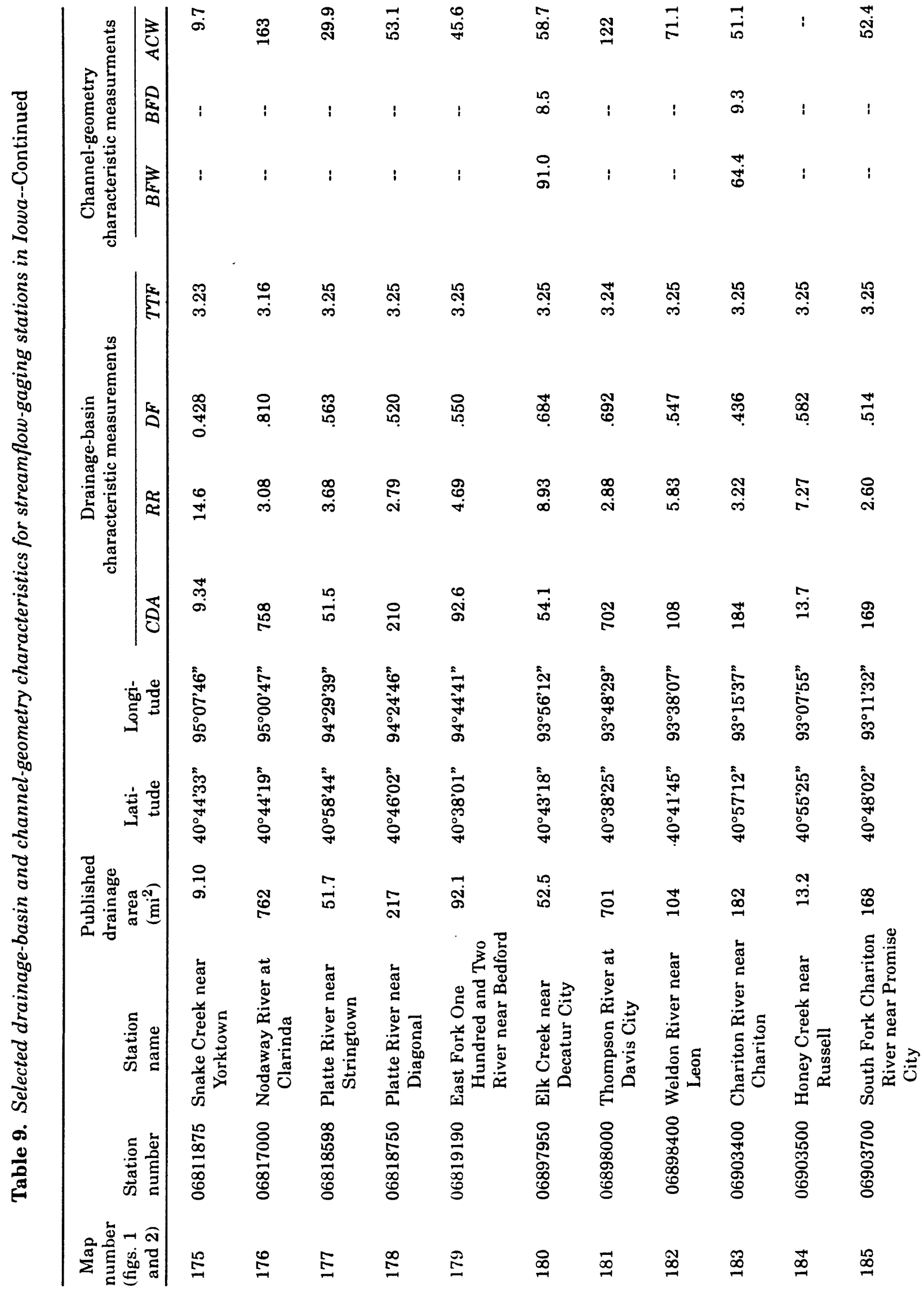




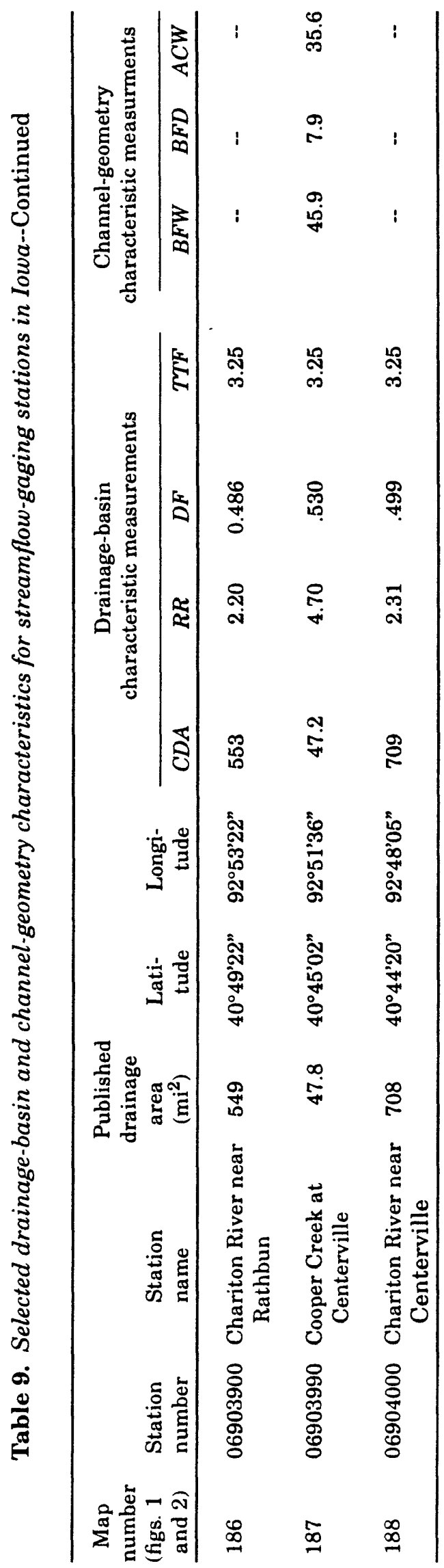

*U.S. GOVERNMENT PRINTING OFFICE:1993-759-354/80097

96 ESTIMATING DESIGN-FLOOD DISCHARGES FOR STREAMS IN IOWA 